\author{
UNIVERSIDADE DE SÃO PAULO \\ FACULDADE DE SAÚDE PÚBLICA
}

\title{
AVALIAÇÃO DA QUALIDADE MICROBIOLÓGICA DE REFEIÇÕ̃ES SERVIDAS A BORDO DE AERONAVES
}

ANA MARIA PINTO ZANARDI

Tese de Doutorado apresentada ao Departamento de Nutrição da

Faculdade de Saúde Pública da Universidade de São Paulo para obtenção do grau de Doutor

Orientador : Prof $^{a}$. Assoc. Elizabeth Aparecida Ferraz da Silva Torres

São Paulo

2002

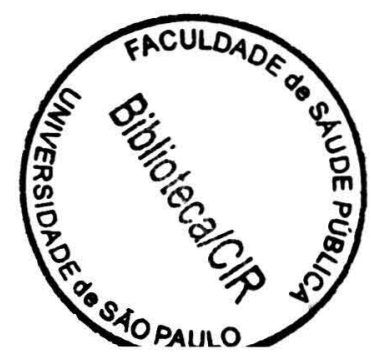


Autorizo, exclusivamente para fins acadêmicos e científicos, a reprodução total ou parcial desta tese, por processos fotocopiadores.

Assinatura:

Local e data:

Zanardi, Ana Maria Pinto

Avaliạ̧ão da qualidade microbiológica de refeições servidas a bordo de aeronaves.São Paulo. Ana Maria Pinto Zanardi. São Paulo, 2002.

$93 \mathrm{p}$. Pública.

Tese (doutorado) - Faculdade de Saúde Pública da USP. Curso de Pós-Graduação em Saúde

Torres, Elizabeth Aparecida Ferraz da Silva, orientador.

$$
4237912002 d x
$$


Aos meus pais

pela minha formação,

incentivo e apoio

Aos meus irmãos

pela amizade e respeito

Biblioteca, CIF -ACULDADE DE SAUDDE PUBLIC IUNVERSIDANF DE SAC RAUL. 
Ao meu esposo Laerte pelo apoio e compreensão

Aos meus filhos Diego Henrique e Pedro Henrique pelo estímulo que representam 
À Professora Associada Elizabeth Aparecida Ferraz da Silva Torres pela orientação, incentivo e apoio constantes

Ao Professor Dr. José Cézar Panetta pelas importantes sugestões $\mathrm{e}$ material bibliográfico

À Prof. ${ }^{a}$ Dra. Maria Helena Matté e Prof. Dr. Glavur Rogério Matté pelo acompanhamento e dedicação

Às Professoras Doutoras Susana Marta Isay Saad

e Simone de Carvalho Balian pelas valiosas sugestões

À Nutricionista Cristiane Nogueira de Barros que possibilitou a execução deste estudo

À Nutricionista Cássia Regina Contiero pela colaboração

À Ana Amélia Scarpel Cavarzeri pela colaboração nas análises

À Agnes Hanashiro pelo incentivo e amizade

À Gianni Yanagubashi pela orientação estatistica

Aos funcionários da Biblioteca da FSP - USP pela colaboração nas consultas bibliográficas

Ao amigos do Laboratório de Saúde Pública pelo apoio e companheirismo

À Universidade de Mogi das Cruzes, através do Programa de Apoio à Qualificação

Docente (PAQD), pela concessão de bolsa de estudos.

A todos os colegas que, de alguma maneira, contribuiram para a realização deste estudo 


\section{INDICE}

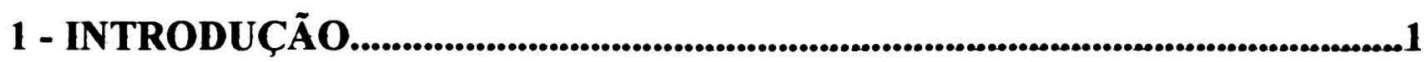

1.1- Doenças Transmitidas por Alimentos ..........................................................

1.2- Microrganismos causadores de doenças transmitidas por alimentos..............11

1.2.1- Microrganismos indicadores: coliformes totais, coliformes fecais e

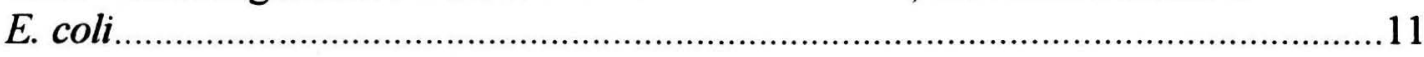

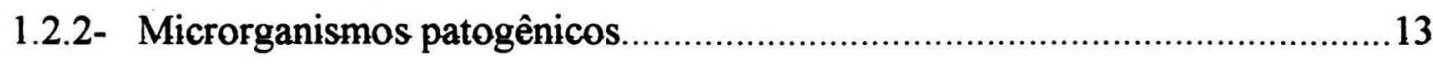

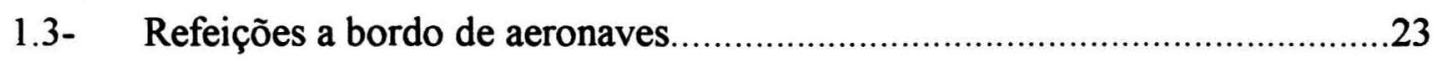

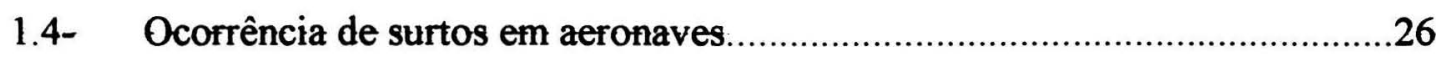

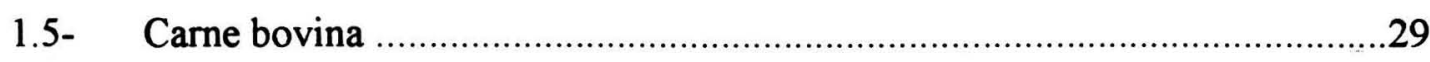

1.6- Testes rápidos para deteç̧ão de microrganismos ....................................33

2- JUSTIFICATIVA

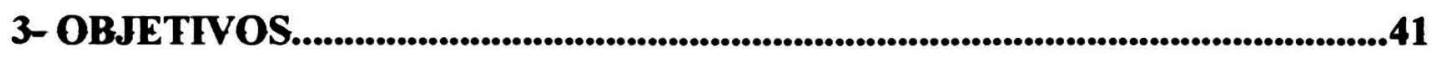

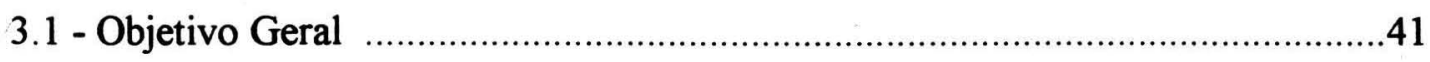

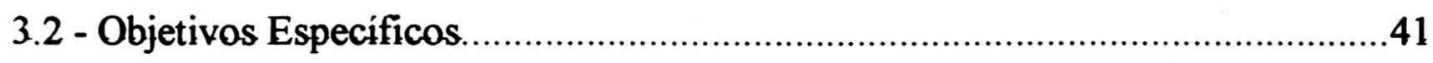

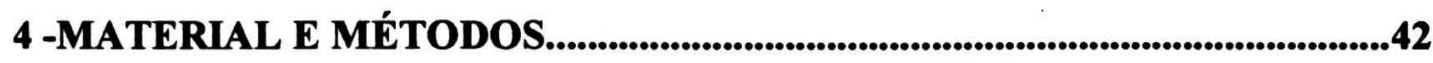

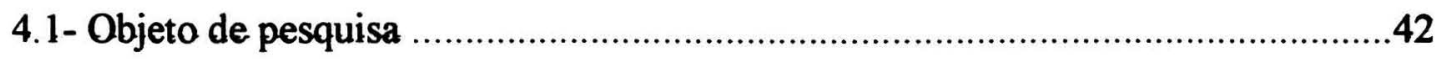

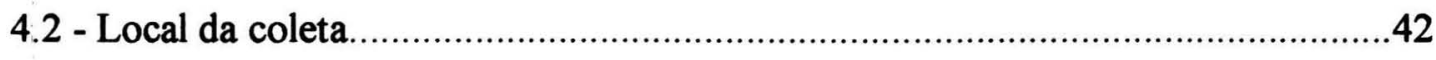

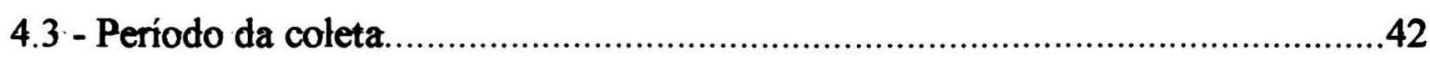

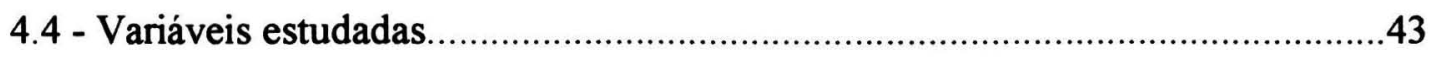

4.4.1 - Variáveis extrínsecas dos alimentos .....................................................43

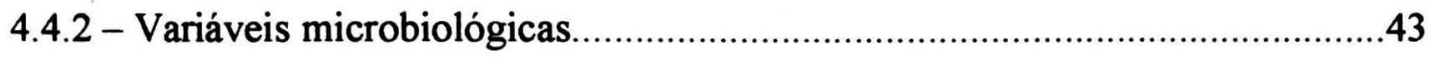


4.5 - Coleta e preparo das amostras para análise

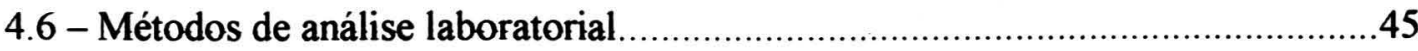

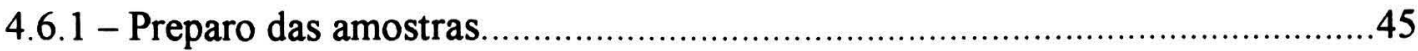

4.6.2 - Procedimentos para as análises microbiológicas.................................... 45

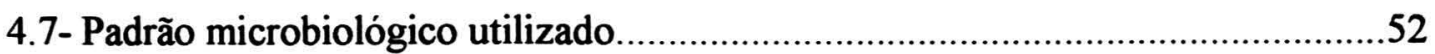

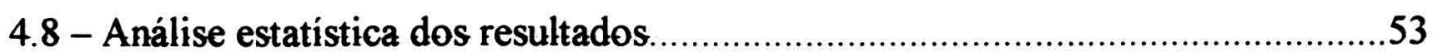

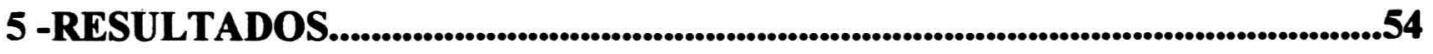

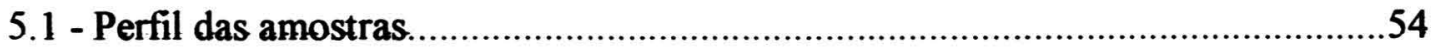

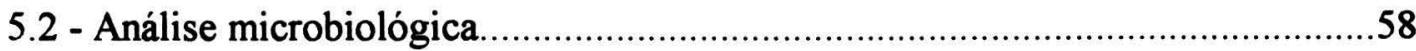

5.2.1 - Relação entre coliformes totais, tipo de preparação, características da preparação e tempo de embalagem......................................................................60

5.2.2 - Relação entre E. coli, tipo de preparação, características da preparação e

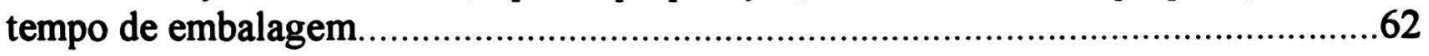

5.2.3 - Relação entre coliformes totais, $E$. coli e temperatura das amostras no momento da coleta.

5.2.4 - Relação entre Salmonella spp, tipo de preparação, características da preparação, tempo de embalagem e temperatura.

5.2.5 - Relação entre Listeria spp, tipo de preparação, características da preparação, tempo de embalagem e temperatura

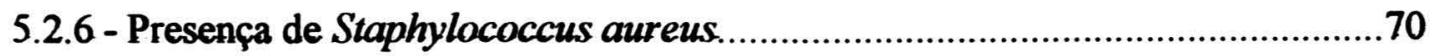

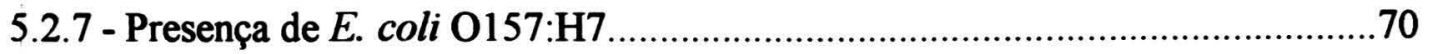

6-DISCUSSÃO

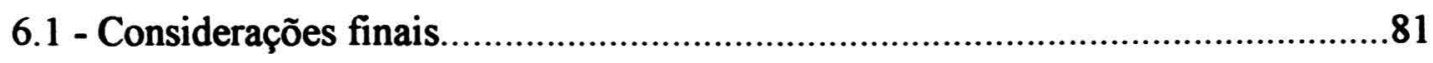

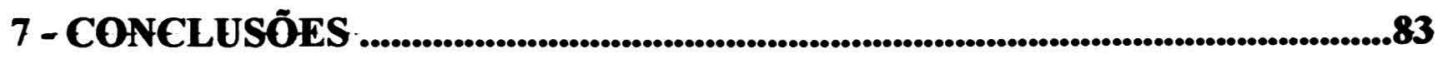

8 -REFERÊNCIAS BIBLIOGRÁFICAS...............................................................85 
ANEXOS... _ _ _ Anexo 1

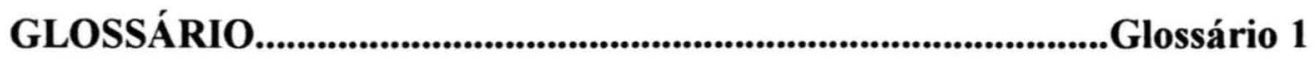




\section{LISTA DE TABELAS, GRÁFICOS E FIGURAS}

Figura 4.1 - Características das preparações quanto ao ponto de cocção . .43

Figura 4.2 - Placa para contagem de coliformes totais.........................................46

Figura 4.3 - Placa para contagem de E. coli ...........................................................46

Figura 4.4 - Confirmação da presença de Staphylococcus aureus.............................48

Figura 4.5 - Verificação da presença de Salmonella spp ......................................49

Figura 4.6 - Verificação da presença de Listeria spp ..............................................51

Figura 4.7- Verificação da presença de E.coli 0157:H7 ........................................52

Quadro 4.1 - Padrões microbiológicos sanitários para alimentos ............................53

Gráfico 5.1 - Distribuição das amostras quanto ao tipo de preparação......................54

Figura 5.1a - Preparações culinárias à base de carne bovina e suas opções …..........55

Figura 5.1b - Preparações culinárias à base de carne bovina e suas opções...............56

Figura 5.1c - Preparações culinárias à base de carne bovina e suas opções................57

Figura 5.2 - Bandeja pronta para consumo a bordo .............................................57

Figura 5.3 - Características da preparação quanto ao ponto de cocção.......................55

Gráfico 5.2 - Distribuição das amostras quanto às características da preparação.......58

Tabela 5.1 - Resultados da contagem de coliformes totais e E. coli em 50 amostras de preparações com carne bovina .......................................................................5

Tabela 5.2 - Distribuição das amostras segundo a contagem de coliformes totais e tipo de preparação.

Tabela 5.3 - Distribuição das amostras segundo contagem de coliformes totais e características da preparação.

Tabela 5.4 - Distribuição das amostras segundo a contagem de coliformes totais e tempo de embalagem.

Tabela 5.5 Distribuição das amostras segundo a contagem de $E$. coli e tipo de preparação. 
Tabela 5.6 - Distribuição das amostras segundo a contagem de E.coli e características da preparação.

Tabela 5.7 - Distribuição das amostras segundo a contagem de $E$. coli e tempo de embalagem.

Tabela 5.8 - Estimativa do coeficiente de correlação linear de Pearson 64

Tabela 5.9 - Distribuição das amostras segundo presença de Salmonella spp por tipo de preparação .65

Tabela 5.10-Distribuição das amostras segundo presença de Salmonella spp e características da preparação

Tabela 5.11 - Distribuição das amostras segundo presença de Salmonella spp e tempo de embalagem.

Tabela 5.12 - Medidas - resumo da temperatura segundo resultado para Salmonella spp

Tabela 5.13 - Distribuição das amostras segundo presença de Listeria spp e tipo de preparação.

Tabela 5.14-Distribuição das amostras segundo presença de

Listeria spp e caracteristicas da preparação

Tabela 5.15 Distribuição das amostras segundo presença de Listeria spp e tempo de embalagem.

Tabela 5.16 Medidas resumo da temperatura segundo resultado para Listeria spp...69 


\section{LISTA DE ANEXOS}

Figura 4.8- Procedimento para teste Reveal Salmonella (Neogen).................Anexos 1

Figura 4.9- Procedimento para teste Reveal E coli 0157:H7 (Neogen)..........Anexos 2

Figura 4.10 - Procedimento para verificação da presença de Listeria spp por meio de Listeria Rapid Test Method - OXOID

Anexos 3

Quadro 5.1- Distribuição das amostras quanto ao tipo de preparação, características da preparação, tempo de embalagem e temperatura no momento da coleta. Anexos 4

Quadro5.2 - Resultados das análises microbiológicas. Anexos 6 


\section{RESUMO}

Zanardi AMP Avaliação da qualidade microbiológica de refeiçōes servidas a bordo de aeronaves. São Paulo; 2002 [Tese de Doutorado em Saúde Pública -FSP / USP]

As doenças de origem alimentar têm sido consideradas um dos problemas de maior importância em saúde pública, estando mais comumente relacionadas à contaminação microbiológica. As refeições servidas a bordo de aeronaves podem servir como veículo dessas doenças, promovendo o perigo de infectar os passageiros e a tripulação. Em função dos perigos que podem ocorrer durante o preparo das refeições de bordo, objetivou-se analisar a qualidade microbiológica dessas refeições, através da contagem de microrganismos indicadores de qualidade higiênico-sanitária e da verificação da presença de Salmonella spp, Listeria spp, Staphylococcus aureus e Escherichia coli 0157:H7. Foram analisadas 50 amostras de preparações à base de carne bovina, distribuídas em função do tipo de preparação, características quanto ao ponto de cocção, tempo de embalagem e temperatura no momento da coleta. As amostras foram coletadas em um serviço de refeições de bordo de um aeroporto do Estado de São Paulo-Brasil. Foram utilizados métodos rápidos para a realização das análises: Petrifilm $(3 \mathrm{M})$ para a contagem de coliformes totais e Escherichia coli, Reveal (Neogen) para a verificação da presença de Salmonella spp e Escherichia coli 0157:H7, Sistema teste rápido(Oxoid) para a verificacão da presença de Listeria spp e Kit Staphytec Plus (Oxoid) para confirmação da presença de Staphylococcus aureus. Observou-se que $70 \%$ das amostras apresentaram coliformes totais e $6 \%$ Escherichia coli. Verificou-se a presença de Salmonella spp em $32 \%$ das amostras e de Listeria spp em 6\% das amostras. S. aureus e E. coli 0157: H7 não foram encontradas nas amostras analisadas. Não houve diferença estatística significativa entre a presença de microrganismos com relação ao tipo de preparação, às caracteristicas quanto ao ponto de cocção, ao tempo de embalagem e à temperatura no momento da coleta. Os resultados permitem concluir que a qualidade microbiológica não é satisfatória, podendo representar um perigo para a saúde dos passageiros e da tripulação, sobretudo se o reaquecimento a bordo não for suficiente.

Descritores: refeições a bordo de aeronaves, doença de origem alimentar, microbiologia dos alimentos, métodos rápidos, carne bovina, saúde pública. 


\section{SUMMARY}

Zanardi AMP Avaliação da qualidade microbiológica de refeições servidas a bordo de aeronaves [Evaluation of microbiological quality of airline meals]. São Paulo; 2002 [Tese de Doutorado em Saúde Pública -FSP / USP]

Foodborne diseases have been considered one of the most important public health issues and they are being commonly associated to microbiological contamination. Airline meals may become a vehicle of these diseases, promoting the hazard of contaminating passengers and crew. Taking into account the damages that can occur during the preparation of airline meals it was decided to investigate the microbiological quality of these food through counting of microorganisms that indicate hygienic-sanitary quality and verifying the presence of Salmonella spp, Listeria spp, Stophylococcus aureus and Escherichia coli 0157:H7. Fifty samples of prepared meat were analyzed, distributed according of preparation types, cooking point's characteristics, packaging times and picking up temperatures. The samples were collected on board service at one of the airports in São Paulo State - Brazil. Rapid test methods were used: Petrifilm (3M) for counting of coliforms amount and Escherichia coli, Reavel (Neogen) for verifying the presence of Salmonella spp and Escherichia coli 0157: H7, Rapid test system (Oxoid) was used to verifying the presence of Listeria spp and Staphytec plus kit (Oxoid) for presence confirmation of Staphylococcus aureus. From the obtained results, it was observed that total coliforms were detected in $70 \%$ of samples and Escherichia coli in 6\%. Salmonella spp were found in $32 \%$ of samples, and Listeria spp were found in $6 \%$ of samples. Staphylococcus aureus and Escherichia coli 0157: H7 were not detected in the analyzed samples. There were not significant statistical differences in the presence of microorganisms regarding preparation type, characteristics due to cooking point, packaging time and temperature at the moment of sampling. The results indicate that the microbiological quality is not satisfactory which may represent a hazard to passengers and crew health especially if the heating on board is not sufficient.

Descriptors: airline meals, foodborne diseases, food microbiology, rapid methods, meat, public health. 


\section{1 - INTRODUÇÃO}

Os alimentos são freqüentemente utilizados como substrato para o desenvolvimento de várias espécies de microrganismos. A pesquisa de bactérias patogênicas e/ou indicadores de condições higiênico-sanitárias auxilia na verificação da qualidade do alimento consumido. A ingestão de alimentos contendo bactérias patogênicas em doses infectantes representa um grande problema de saúde pública (LÍRIO et al. 1998).

Devido à relevância da questão da qualidade dos alimentos e da dieta, é muito importante incorporar o componente de segurança nutricional ao conceito de segurança alimentar. Isto implica que todos os cidadãos consumam alimentos que satisfaçam suas necessidades nutricionais e seus hábitos culturalmente construídos, visando a promoção da saúde (NARDIN et al.1997).

Segurança alimentar é um termo abrangente, que significa que todas as pessoas, em todos os momentos, devem ter acesso a uma alimentação suficiente para uma vida ativa e saudável, disponível portanto, em quantidade e qualidade nutricionalmente adequadas, além de ser livre de contaminações que possam levar ao desenvolvimento de doenças de origem alimentar (WHO 1984).

A segurança alimentar é importante na avaliação da qualidade dos alimentos, se estes apresentam-se inseguros, suas outras qualidades perdem a importância (ROGAN e BERNARDI, 1996).

A segurança alimentar pode ser vista sob o ponto de vista quantitativo, "food security", a qual é obtida através do aumento da renda familiar, conjuntamente com uma oferta adequada de alimentos via produção interna ou importação (SPERS e 
KASSOUF, 1996b). A segurança alimentar é definida sob o ponto de vista qualitativo, "food safety", como "o inverso do risco alimentar; isto é, a probabilidade de não sofrer dano algum pelo consumo de um alimento" (HENSON e TRAILL, 1993, SPERS e KASSOUF, 1996b).

O conceito de segurança alimentar tem sido amplamente discutido pelos diferentes setores responsáveis pela produção, distribuição e elaboração de alimentos, porém, muito ainda precisa ser realizado (GERMANO PML e GERMANO MIS, 2000).

A preocupação com a alimentação adequada e saudável da população é um componente essencial para as metas de saúde dos países para o futuro. A meta vai depender do estágio de desenvolvimento e do interesse de cada país em desenvolver programas que garantirão o “food safety” (SPERS e KASSOUF, 1996a).

Durante a produção, processamento, embalagem, transporte, preparação, manutenção e consumo, qualquer alimento pode ser exposto à contaminação por substâncias tóxicas ou por microrganismos (ICMSF 1997).

$\mathrm{Na}$ ciência da nutrição tem-se observado avanços, não só explorando a qualidade nutricional do alimento, como também na prevenção e no controle de doenças (SPERS e KASSOUF, 1996a).

Segundo SOLÍS (1999), rastreabilidade, controle de qualidade, monitoramento documentado dos processos e rotulagem confiável, são as ferramentas que permitirão a segurança dos alimentos. Nas indústrias, centros de distribuição, supermercados e comércio varejista em geral, os maiores problemas relacionados à segurança alimentar estão nos alimentos perecíveis, com 
contaminações microbiológicas elevadas, devido à refrigeração inadequada, elevado tempo de exposição, condições inadequadas de armazenagem e manipulação imprópria.

De acordo com SPERS (2000), as organizações relacionadas com a qualidade e segurança em alimentos são:

- Vigilância Sanitária : entidade responsável pela segurança do alimento no Brasil; vinculada à Agência Nacional de Vigilância Sanitária do Ministério da Saúde.

- FAO : Food and Agriculture Organization, vinculada à Organização das Nações Unidas (ONU).

- OMS : Organização Mundial da Saúde (World Health Organization-WHO), pesquisa e define os padrões internacionais de segurança.

- OMC : Organização Mundial do Comércio (World Trade Organization-WTO), órgão responsável em solecionar conflitos comerciais entre países, como é o caso das barreiras não - tarifárias.

\section{1 - Doenças Transmitidas Por Alimentos}

As doenças veiculadas por alimentos têm sido consideradas um dos problemas mais importantes de saúde pública. A origem e investigação de doenças alimentares é complexa, relacionada a diversos fatores ligados à cadeia epidemiológica de enfermidades transmissiveis, que envolvem a tríade: agente, meio ambiente e indivíduos susceptíveis. Dentre os fatores comumente associados às doenças de origem alimentar, podem destacar-se as mudanças das características demográficas de certas regiões, hábitos culturais, tecnologia empregada desde a 
contaminações microbiológicas elevadas, devido à refrigeração inadequada, elevado tempo de exposição, condições inadequadas de armazenagem e manipulação imprópria.

De acordo com SPERS (2000), as organizações relacionadas com a qualidade e segurança em alimentos são:

- Vigilância Sanitária : entidade responsável pela segurança do alimento no Brasil; vinculada à Agência Nacional de Vigilância Sanitária do Ministério da Saúde.

- FAO : Food and Agriculture Organization, vinculada à Organização das Nações Unidas (ONU).

- OMS : Organização Mundial da Saúde (World Health Organization-WHO), pesquisa e define os padrões internacionais de segurança.

- OMC : Organização Mundial do Comércio (World Trade Organization-WTO), órgão responsável em solecionar conflitos comerciais entre paises, como é o caso das barreiras não - tarifárias.

\section{1 - Doenças Transmitidas Por Alimentos}

As doenças veiculadas por alimentos têm sido consideradas um dos problemas mais importantes de saúde pública. A origem e investigação de doenças alimentares é complexa, relacionada a diversos fatores ligados à cadeia epidemiológica de enfermidades transmissiveis, que envolvem a triade: agente, meio ambiente e indivíduos susceptiveis. Dentre os fatores comumente associados às doenças de origem alimentar, podem destacar-se as mudanças das características demográficas de certas regiões, hábitos culturais, tecnologia empregada desde a 
produção até a comercialização dos alimentos, tendências globais de mercado e mecanismos de virulência e adaptação dos microrganismos (ALTEKRUSE et al.1997).

Estas doenças ocupam lugar de destaque em função do grande número de microrganismos envolvidos, da diversidade dos períodos de incubação, da variabilidade dos quadros clínicos e principalmente da elevada quantidade de produtos de origem animal e vegetal que podem veicular esses agentes (LEDERER 1991e RIEDEL, 1992).

As doenças de origem alimentar apresentam sintomas representados principalmente por perturbações gastrintestinais, podendo causar distúrbios no sistema nervoso, na corrente circulatória, no figado e em outros órgãos quando não se limitam ao trato gastrintestinal (FRANCO e LANDGRAF, 1996). Essas doenças, especialmente aquelas causadas por microrganismos patogênicos persistem como um sério problema em todos os países. A diarréia é uma característica da maioria dessas doenças e até $70 \%$ dos episódios de diarréia podem resultar da ingestão de alimentos e água contaminados (OMS 2002).

Muitos microrganismos que causam enfermidades no homem são parte integrante da microbiota intestinal normal dos animais destinados à produção de alimentos e com eles convivem sem causar danos à sua saúde. A carne, leite e ovos desses animais podem ser contaminados através dos alimentos consumidos por eles, pelo uso indevido de produtos veterinários ou ainda, por práticas inadequadas na fazenda. Os alimentos também podem contaminar-se na etapa de processamento e, 
continuam ainda expostos à contaminação nos centros de distribuição e finalmente no domicílio do consumidor (ALMEIDA 1998).

As enfermidades ou doenças de origem alimentar freqüentemente ocorrem na forma de epidemias instantâneas, pois na maioria dos casos surgem num intervalo de tempo semelhante e equivalente ao período de incubação. Como o número de casos geralmente não é elevado e está restrito no espaço, são denominados surtos epidêmicos ou apenas surtos (SPERS e KASSOUF, 1996b).

Um dos problemas mais importantes das doenças de origem alimentar é o crescente número de novos agentes patogênicos nos alimentos. Por exemplo, entre 1973 e 1988 houve a propagação de bactérias que não eram reconhecidas anteriormente como causas importantes de doenças transmitidas por alimentos, como a Escherichia coli 0157:H7 e a Salmonella enteritidis (FDA 1996). A Escherichia coli 0157:H7 é o agente causal da colite hemorrágica e a Salmonella enteritidis é a causa dominante de salmonelose ( JIANG e DOYLE, 1999).

Os alimentos podem ser contaminados em sua origem, bem como em cada uma das etapas da cadeia produtiva, até o momento de preparo e ingestão (HANASHIRO et al 1999).

Um trabalho realizado por BONNER et al. (2001), no qual foram analisados surtos de doenças transmitidas por alimentos na Irlanda, entre 1998 e 1999, os principais fatores que contribuiram para a ocorrência dos surtos foram a cocção e o reaquecimento inadequado (36\%), o armazenamento inadequado (29\%), a contaminação cruzada (31\%) e o preparo antecipado (19\%). 
Para evitar-se as doenças de origem alimentar, deve-se enfatizar as situações que visem a prevenção da veiculação de agentes patogênicos de maior severidade e as condições de maior risco.

Qualquer iniciativa que tenha por finalidade garantir a inocuidade dos alimentos deve ser focalizada no controle dos perigos potenciais de contaminação e nos alimentos que representam maior risco à saúde pública (ALMEIDA 1998).

O primeiro passo para avaliar as doenças de origem alimentar é realizar um estudo epidemiológico abrangente e aprofundado em relação aos vários agentes etiológicos causadores das intoxicações e infecções alimentares. Dos estudos estatísticos observados nos boletins da OMS, pode-se notar que, em se tratando de doenças de origem alimentar, as ocorrências mais comuns são aquelas que envolvem as bactérias e seus produtos tóxicos, os vírus, fungos e parasitas (ZANARDI 1998).

Surtos de toxinfecção alimentar são bastante freqüentes no mundo todo, dentre os mais comuns estão os causados pela toxina termoestável produzida por Staphylococcus aureus (ALCARÁZ et al., 1997 e MURRAY, 1995).

Os países desenvolvidos são os que mais possuem dados epidemiológicos sobre intoxicações de origem alimentar. No período de 1962 a 1971 mais de $5 \%$ das toxinfecções alimentares relatadas na Inglaterra e País de Gales foram devidas ao Staphylococcus aureus. Nos Estados Unidos, de 1969 a 1973, 30\% das intoxicações alimentares foram devidas ao Staphylococcus aureus. ALCARAZ et al. (1997) relataram que o Staphylococcus aureus enterotoxigênico é o agente responsável por cerca de $45 \%$ das intoxicações de origem alimentar no mundo, sendo os manipuladores de alimentos importantes na veiculação deste agente. 
A exata incidência das Doenças Transmitidas por Alimentos (DTAs) não é conhecida devido às limitações das notificações epidemiológicas. Estima-se que o número de casos nos estados Unidos varie anualmente entre 1,4 a 81 milhões, presumindo-se que 5\% dos casos gerem complicações crônicas e 200 a 9000 óbitos (VIANA 1998).

Nos Estados Unidos, estima-se que ocorreram cerca de 6,5 milhões de casos de toxinfecções e 9.000 óbitos, por ano, em conseqüência das doenças transmitidas por alimentos (CDC 1999). Especificamente na Califórnia, no período de 1993 a 1994, dos 32 surtos de doenças transmitidas por alimentos, as bactérias patogênicas apresentaram-se como agente etiológico confirmado na seguinte proporção: Salmonella (63\%), Shigella (13\%), S. aureus (9\%), E.coli 0157: H7 (9\%) e C. botulinum (6\%) (CDHS 1995).

De acordo com dados de etiologia da doença de origem alimentar, na América Latina e Caribe, no período de 1995 a 1997, a Salmonella spp foi implicada em $37 \%$ dos surtos, seguida de $S$. aureus $(36,6 \%)$, Escherichia coli $(11,4 \%), C$. perfringens $(4,2 \%), V$. cholerae $(4,2 \%)$, Shigella spp $(3,1 \%), B$. cereus $(1,3 \%), C$. botulinum $(0,4 \%)$, V parahemolyticus $(0,2 \%)$ dentre outras $(1,6 \%)$ (WHO 2002$)$.

Dados do CDC (2000), no período de 1996 a 1999, apresentam um declínio de $26 \%$ na incidência de Campylobacter. A incidência de shigelose decresceu $44 \%$ enquanto que a de E.coli $0157: \mathrm{H} 7$ decresceu $22 \%$. Em relação à salmonelose a incidência nos Estados Unidos decresceu 15\% de 1996 a 1998 e aumentou 20\% de 1998 a 1999, em estados como Connecticut, Georgia, Minnesota e Oregon e declinou na Califórnia. 
As doenças transmitidas por alimentos contribuem para a ocorrência de milhares de mortes, nos Estados Unidos, todo ano. Uma série de bactérias patogênicas como Escherichia coli 0157:H7, Salmonella, Campylobacter foram encontradas em carnes e frangos (YANG et al., 2000).

Deve-se considerar que, de uma maneira geral, existe perda de informações epidemiológicas, subestimando-se o número real de doenças transmitidas por alimentos. Estima-se que apenas 1 a $10 \%$ dos casos sejam computados pelas estatísticas oficiais (MOSSEL e MORENO GARCIA, 1982).

O decréscimo na incidência de doenças transmitidas por alimentos (DTAs), nos Estados Unidos, culminou com os esforços preventivos das doenças, incluindo implementação de mudanças no processamento de carnes e aves, novos requerimentos de serviços de alimentação e aumento de atenção nas boas práticas na produção de produtos agrícolas e de ovos nas fazendas (CDC 1999).

Certas limitações são feitas em relação aos resultados obtidos nos dados apresentados, pois embora o controle pelo FoodNet tenha abrangido $9 \%$ da população americana em 1999, essas áreas não correspondiam a uma amostra nacionalmente representativa. Além disso, os dados estão limitados às doenças confirmadas pelos laboratórios, porém, muitas das DTAs não são comunicadas aos departamentos de saúde dos estados e também muitas doenças confirmadas pelos laboratórios podem ter sido adquiridas através de rotas que não sejam por alimentos (CDC 1999).

Nos paises em desenvolvimento tem-se constatado a necessidade de melhorar as condições fisicas dos estabelecimentos produtores de refeições, embora seja mais 
importante garantir a segurança das operações de processamento, muitas das quais podem levar à proliferação de microrganismos (BRYAN 1992).

No Brasil, tem-se como panorama atual da vigilância de alimentos uma alta taxa de doenças transmitidas por alimentos, doenças emergentes desafiando as atuais medidas de controle, mudanças de hábitos alimentares, globalização da economia, alta mobilidade populacional, falta de higiene no preparo e produção, precariedade dos sistemas de vigilância, precariedade dos serviços de saúde pública e ausência de programas de educação sanitária (CVE 2000).

Espera-se que, seguindo o exemplo dos Estados Unidos, o Brasil também possa dispor de dados para deixar a população informada quanto aos acontecimentos da saúde no país bem como os perigos a que ela possivelmente esteja sujeita.

Os indivíduos afetados por doenças transmitidas por alimentos podem não procurar orientação médica e, se não o fizerem, sua doença pode não ser reconhecida como de origem alimentar quanto à sua origem, ou pode não ser notificada à autoridade competente para registro (WHO 2002).

O turismo e a comercialização internacional de alimentos, atualmente em ascensão devido à globalização, conduzem a importantes benefícios sociais e econômicos, entretanto podem facilitar a disseminação de patógenos em todo o mundo. A estas facilidades acrescenta-se a acelerada mudança nos hábitos alimentares, as novas técnicas de produção, preparo e distribuição dos alimentos, entre outras, sendo portanto, de fundamental importância um efetivo controle higiênico para evitar as diversas conseqüências das DTAs à economia e à saúde pública (VIANA 1998). 
A ocorrência de toxinfecções de origem bacteriana depende de um conjunto de circunstâncias e de alguns ou de todos os seguintes fatores: o microrganismo infectante, os gêneros alimentícios e os manipuladores de alimentos; as maõs dos manipuladores de alimentos transmitindo os microrganismos dos alimentos crus para os alimentos cozidos e equipamentos; superfícies contaminadas por alimentos crus; alimentos favoráveis ao crescimento bacteriano; condições favoráveis para estocagem à temperaturas "mornas" por um período de 2 horas ou mais e indivíduos susceptíveis (HOBBS e ROBERTS, 1998).

A suscetibilidade à infeç̧ão pode variar com uma série de fatores, como idade, saúde em geral, nutrição, estado imune e se o indivíduo encontra-se ou não em tratamento médico (WHO 2002).

Atualmente, uma série de parasitas, vírus e principalmente bactérias passaram a ter reconhecida a sua veiculação através dos alimentos e resultaram em diversos surtos de DTAs. Esses microrganismos que classicamente não eram reconhecidos como causadores de DTAs são denominados patógenos emergentes. Os fatores contribuintes para a ocorrência de patógenos emergentes são, entre outros: mudanças genéticas nos microrganismos que resultam no aumento da virulência; mudanças nos hábitos alimentares e atitudes sociais; mudanças nos sistemas de produção e distribuição dos alimentos; aumento do número de individuos imunodeprimidos e aperfeiçoamento dos métodos de deteç̧ão de patógenos (SMITH e FRATAMICO, 1995).

Dados da WHO (2002) indicam que apenas um pequeno número de fatores relacionados à manipulação dos alimentos é responsável por episódios de doenças de 
origem alimentar, sendo os erros mais comuns: preparo dos alimentos com antecedência aliado a seu armazenamento, cozimento ou reaquecimento inadequado, contaminação cruzada e pessoas com pouca higiene pessoal manipulando os alimentos.

\section{2 - Microrganismos causadores de Doenças Transmitidas por}

\section{Alimentos}

Os microrganismos vêm sendo utilizados na avaliação da qualidade microbiológica da água há muito tempo, e mais recentemente em alimentos. Os microrganismos indicadores são grupos ou espécies de microrganismos que quando presentes em um alimento podem fornecer informações sobre a ocorrência de contaminação de origem fecal, sobre a provável presença de patógenos ou sobre a deterioração potencial do alimento, além de poder indicar condições sanitárias inadequadas durante o armazenamento ou processamento (FRANCO e LANDGRAF, 1996).

\subsection{1- Microrganismos indicadores: coliformes totais, coliformes fecais e $\boldsymbol{E}$. coli}

A pesquisa de microrganismos indicadores é utilizada na avaliação da qualidade higiênico-sanitária dos alimentos, sendo uma alternativa no monitoramento de patógenos específicos (ADAMS e MOSS, 1997).

Esses microrganismos são representados basicamente por coliformes totais, coliformes fecais e $E$. coli 


\section{- Coliformes totais}

Este grupo é composto por bactérias da família Enterobacteriaceae, que são capazes de fermentar a lactose, com produção de gás, quando incubados entre 35 e $37^{\circ} \mathrm{C}$, por 48 horas. Fazem parte desse grupo as bactérias pertencentes aos gêneros Escherichia, Enterobacter, Citrobacter e Klebsiella. Destes microrganismos, apenas a Escherichia coli tem como habitat primário o trato intestinal do homem e animais (ADAMS e MOSS, 1997).

A presença de coliformes totais nos alimentos processados é uma evidência de contaminação pós-processamento, indicando práticas inadequadas de higiene (SILVA et al., 1997).

\section{- Coliformes fecais e Escherichia coli}

As bactérias pertencentes a este grupo correspondem aos coliformes totais que apresentam a capacidade de continuar fermentando lactose com produção de gás quando incubadas à temperatura de 44 a $45,5^{\circ} \mathrm{C}$. A pesquisa de coliformes fecais ou de $E$. coli nos alimentos fornece informações sobre as condições higiênicas do produto e melhor indicação da eventual presença de enteropatógenos (FRANCO e LANDGRAF, 1996).

A presença de coliformes de origem fecal em alimentos indica que existe 0 risco que também estejam presentes nos alimentos outros patógenos entéricos como Salmonella, Shigella e outros (ALMEIDA et al., 1996)

Em alimentos processados, a presença de um número considerável de coliformes ou de Enterobactericeae indica processamento inadequado e/ou 
recontaminação pós-processamento, ou proliferação microbiana, o que poderia permitir a multiplicação de microrganismos patogênicos e toxigênicos (FRANCO e LANDGRAF, 1996).

Escherichia coli é uma bactéria mesófila, capaz de se desenvolver entre $7^{\circ} \mathrm{C}$ e $46^{\circ} \mathrm{C}$, sendo $37^{\circ} \mathrm{C}$ a temperatura ótima. Ela não apresenta termoresistência, sendo destruída a $60^{\circ} \mathrm{C}$, em poucos segundos, porém pode resistir por um longo periodo de tempo sob temperaturas de refrigeração (GERMANO PML e GERMANO MIS, 2001).

\subsection{2 - Microrganismos patogênicos}

Dentre os microrganismos patogênicos de interesse em alimentos, destacamse os enteropatogênicos correspondentes àqueles cuja patologia se expressa no trato gastrintestinal. Muitos outros patógenos que são veiculados por alimentos utilizam-se do trato gastrintestinal como porta de entrada do organismo humano, expressando sua patogenicidade em outros locais (FRANCO e LANDGRAF, 1996).

Dentre os agentes etiológicos patogênicos relatados em vários surtos pode-se citar: Salmonella spp, Listeria spp, Staphylococcus aureus e E. coli 0157:H7.

\section{- Salmonella spp}

O gênero Salmonella tem sido de importância para a saúde pública devido a seu caráter zoonótico e sua ampla distribuição na natureza, sendo responsável por surtos de doenças transmitidas por alimentos em diversos paises do mundo inclusive no Brasil (CAFFER e EIGER 1994; ARAUJO et al. 1995; CDC 1999). 
recontaminação pós-processamento, ou proliferação microbiana, o que poderia permitir a multiplicação de microrganismos patogênicos e toxigênicos (FRANCO e LANDGRAF, 1996).

Escherichia coli é uma bactéria mesófila, capaz de se desenvolver entre $7^{\circ} \mathrm{C}$ e $46^{\circ} \mathrm{C}$, sendo $37^{\circ} \mathrm{C}$ a temperatura ótima. Ela não apresenta termoresistência, sendo destruída a $60^{\circ} \mathrm{C}$, em poucos segundos, porém pode resistir por um longo período de tempo sob temperaturas de refrigeração (GERMANO PML e GERMANO MIS, 2001).

\subsection{2 - Microrganismos patogênicos}

Dentre os microrganismos patogênicos de interesse em alimentos, destacamse os enteropatogênicos correspondentes àqueles cuja patologia se expressa no trato gastrintestinal. Muitos outros patógenos que são veiculados por alimentos utilizam-se do trato gastrintestinal como porta de entrada do organismo humano, expressando sua patogenicidade em outros locais (FRANCO e LANDGRAF, 1996).

Dentre os agentes etiológicos patogênicos relatados em vários surtos pode-se citar: Salmonella spp, Listeria spp, Staphylococcus aureus e E. coli 0157:H7.

\section{- Salmonella spp}

O gênero Salmonella tem sido de importância para a saúde pública devido a seu caráter zoonótico e sua ampla distribuição na natureza, sendo responsável por surtos de doenças transmitidas por alimentos em diversos paises do mundo inclusive no Brasil (CAFFER e EIGER 1994; ARAUJO et al. 1995; CDC 1999). 
Registros epidemiológicos nos Estados Unidos têm apresentado a Salmonella spp como uma importante bactéria causadora de doenças transmitidas por alimentos (DOYLE et al.,1996). Nesse pais, onde os surtos são notificados de forma mais sistemática, ocorreram 549 episódios por Salmonella, representando $69 \%$ do total de notificações, no período de 1988 a 1992 . Destes casos, $60 \%$ foram por Salmonella enteritidis (BEAN et al., 1997).

Nos países da Europa, os dados revelam situação semelhante à relatada pelos Estados Unidos (FANTASIA e FILETICI, 1994).

Inúmeros surtos de toxinfecção alimentar causados por Salmonella spp são conhecidos envolvendo os mais variados tipos de alimentos. Verifica-se que carne bovina, carne de aves e outros tipos são os alimentos mais freqüentemente envolvidos. Há relatos de alguns episódios de salmonelose de origem alimentar associados a viagens aéreas internacionais. A preparação e o armazenamento de grandes quantidades de alimentos em serviços de refeições de bordo, manuseio excessivo, controle inadequado de temperatura das câmaras e conservação dos alimentos prontos para consumo são condições favoráveis para a multiplicação de Salmonella (FRANCO e LANDGRAF, 1996).

Em um trabalho realizado por JAKABI et al. (1999), dentre os sorotipos de Salmonella encontrados em diferentes tipos de alimentos envolvidos em surtos na grande São Paulo no ano de 1994, verificou-se a presença de Salmonella enteritidis em carne assada. No ano de 1995, a mesma bactéria foi encontrada em diversos tipos de alimentos, como ovos, mousse de chocolate, mousse de limão, espeto de almondega, bolo e maioneses. ALMEIDA et al. (2000) relataram que, no periodo de 
1990 a 1999, 57,4\% das amostras de carnes e derivados analisadas, apresentaram testes positivos para Salmonella enteritidis.

A freqüência de isolamento de cepas de Salmonella em alimentos indica fator de risco de toxinfecção alimentar (LIRIO et al., 1998).

A temperatura ideal para a multiplicação de Salmonella é de 35 a $37^{\circ} \mathrm{C}$, sendo que, muitos estudos indicam que valores máximo e mínimo dependem do sorotipo (FRANCO e LANDGRAF,1996).

\section{- Staphylococcus aureus}

O homem e os animais são importantes reservatórios de $S$. aureus. A cavidade nasal é o principal habitat dos Staphylococcus no homem e, a partir deste foco, atingem tanto a epiderme e feridas como também qualquer superficie e objeto que o homem tenha entrado em contato. Os portadores nasais e os manipuladores de alimentos que apresentam feridas infectadas com $S$. aureus nas mãos e nos braços são importantes fontes de contaminação do alimento (FRANCO e LANDGRAF, 1996). A manipulação inadequada dos alimentos, por parte dos portadores e por pessoas com feridas nos braços e nas mãos, constituem a principal fonte de contaminação dos alimentos por Staphylococcus aureus (ALMEIDA et al., 1996).

Os Staphylococcus aureus são bactérias mesófilas apresentando temperatura de crescimento na faixa de $7^{\circ} \mathrm{C}$ a $47,8^{\circ} \mathrm{C}$, com crescimento ótimo entre 40 e $45^{\circ} \mathrm{C}$; as enterotoxinas são produzidas entre 10 e $46^{\circ} \mathrm{C}$, são termoresistentes, não sendo facilmente destruídas pelo calor (FRANCO e LANDGRAF, 1996). 


\section{- Listeria spp}

Devido à sua ampla distribuição na natureza, Listeria spp pode contaminar uma infinidade de alimentos, entre eles a carne, que se constitui em um excelente meio para multiplicação dessa bactéria (PICCHI et al., 1999).

Diversos surtos ocorreram devido à presença de Listeria spp, envolvendo diferentes produtos cárneos (DESTRO et al. 1991; JAY 1996; NUTSCH et al. 1998; PICCHI et al. 1999; ARIYAPITIPUN 2000). A detecção de Listeria apresenta interesse à indústria cárnica, devido à sua associação com animais e à sua reconhecida patogenicidade (DOYLE 1988).

\section{- Listeria monocytogenes}

Listeria monocytogenes é uma bactéria Gram-positiva psicrotrófica, associada a toxinfeç̧ões alimentares. É um microrganismo não formador de esporos, anaeróbio facultativo e que está associado a doenças transmitidas por alimentos. A temperatura ótima para o seu crescimento está entre 30 e $37^{\circ} \mathrm{C}$, sendo capaz de muttiplicar-se entre 1 e $45^{\circ} \mathrm{C}$ (SEELIGER e JONES, 1986), podendo também multiplicar-se à temperatura de $0^{\circ} \mathrm{C}$ (WELBORN e WILLIANS Jr, 1999). Este microrganismo suporta repetidos congelamentos e descongelamentos. Esta bactéria, amplamente distribuída na natureza, pode portanto, desenvolver-se em ampla faixa de temperatura, sendo também uma das células vegetativas de maior resistência térmica. Dessa forma, sua entrada no ambiente da indústria de alimentos, deve ser prevenida (FRANCO e LANDGRAF, 1996). Apesar da Listeria ser avaliada como um importante patógeno desde 1925 e, como agente de listeriose humana desde 
1929, somente na década de 80 foi reconhecida sua presença em alimentos (UBOLDI EIROA 1990). A partir de então, reconheceu-se sua importância em saúde pública, com sua associação a infecções alimentares em humanos (ARCHER 1996 e BRACKET 1998).

Listeria monocytogenes encontra-se amplamente disseminada na natureza. Tanto o homem como os animais e o ambiente servem como reservatório desta bactéria. $\mathrm{Na}$ década de 80 ocorreram vários surtos de listeriose. $\mathrm{O}$ primeiro deles ocorreu no Canadá, tendo a salada de repolho tipo "coleslaw" como alimento incriminado. Um surto ocorrido em 1983, nos Estados Unidos, envolveu 49 indivíduos , com índice de mortalidade de $29 \%$ e o leite pasteurizado foi o alimento incriminado. L. monocytogenes tem sido isolada de diferentes alimentos tais como leite cru e pasteurizado, queijos, carne bovina, suína, de aves, peixes, embutidos, carne moída de diferentes animais, produtos cárneos crus e termoprocessados, além de produtos de origem vegetal, de origem marinha e refeições preparadas. Estes isolamentos tem sido realizados tanto em outros paises, como no Brasil (FRANCO e LANDGRAF, 1996).

Listeria monocytogenes é um microrganismo patogênico capaz de causar doenças com altas taxas de mortalidade em indivíduos susceptiveis. Suas características tais como estar amplamente distribuído na natureza, capacidade de sobreviver por períodos longos a condições adversas, capacidade de crescimento a temperaturas de refrigeração, demonstram a importância deste patógeno como causador de doença de origem alimentar (DESTRO e SERRANO, 1990). 
Embora exista uma margem de risco para todos os consumidores, este patógeno apresenta como grupo de risco mulheres grávidas, crianças, idosos e consumidores com a saúde comprometida, envolvendo pacientes imunodeprimidos (ALMEIDA et al., 1999). A listeriose em gestantes geralmente manifesta-se por febre, calafrios, dor de cabeça, dor nas costas e urina incolor; podendo ocorrer casos de mulheres grávidas, portadoras assintomáticas ou com sintomas atenuados. A infecção na gestante leva à infecção no feto, ocorrendo geralmente no terceiro trimestre de gestação, porém, infecções anteriores ao quarto mês gestacional já foram relatadas. A infecção pode levar ao aborto ou natimorto imediatamente após os primeiros sinais de febre e calafrios (ROCOURT 1996).

Estes fatores, juntamente com o isolamento do microrganismo em alimentos do tipo "prontos para consumo", fez com que as indústrias alimentícias, autoridades de Saúde Pública e pesquisadores em vários países concentrassem sua atenção nesta bactéria. Devido à natureza psicrotrófica, a preocupação tornou-se ainda maior, pois o risco de listeriose aumenta na proporção direta da produção de alimentos frescos e processados, prontos para consumo e que usualmente são conservados à temperatura de refrigeração (LOGUERCIO et al., 2001).

Devido à severidade das infecções causadas por Listeria, onde a taxa de mortalidade pode alcançar cerca de $50 \%$, e por não ser conhecida até o momento a dose infectante mínima, o Food and Drug Administration dos Estados Unidos estabeleceu a norma de tolerância zero para o microrganismo em alimentos prontos para consumo. O Brasil e alguns países da Europa têm sido mais tolerantes, 
admitindo a presença de até 100 células de $L$. monocytogenes por grama ou mililitro de alimento (ALMEIDA et al., 1999).

O primeiro surto de listeriose humana, veiculado por alimentos ocorreu em 1979, nos EUA, quando 20 pacientes internados, apresentaram a doença, devido ao consumo de saladas de alface, tomate e salsão (HO et al. 1986). Outro surto envolvendo 41 pessoas foi relatado em 1981 no Canadá devido ao consumo de salada de repolho contaminada pelo uso de adubo orgânico contendo esterco de ovinos infectados pela bactéria, sendo o alimento mantido por tempo prolongado sob refrigeração (SCHLEH III 1983).

Dentre os alimentos envolvidos em surtos, mereceram maior destaque os produtos lácteos e os cárneos contaminados. Os alimentos lácteos têm sido relatados como os mais importantes veículos de transmissão de listeriose (DOYLE et al., 1987; DESTRO et al., 1991 e SILVA et al., 1998).

A dose mínima capaz de causar infecção em seres humanos, ainda não é conhecida. Para patógenos de origem alimentar, a dose infectante depende de certas variáveis como a condição do hospedeiro, a virulência da cepa , o tipo e a quantidade de alimento consumido e a concentração do patógeno no alimento (ROCOURT 1996).

A parcela da população, que quando infectada, está sujeita a maior risco são as mulheres grávidas, bebês, idosos e indivíduos com o sistema imunológico comprometido (DESTRO 1991; SMITH 1999).

DESTRO e SERRANO (1990), a partir de uma revisão, considerando a epidemiologia e a ocorrência em alimentos do gênero Listeria, constataram que os 
produtos cárneos termoprocessados foram encontrados entre 5 a $8,3 \%$ das amostras analisadas, nos Estado Unidos.

Pesquisas realizadas nos Estados Unidos têm constatado que a bactéria Listeria monocytogenes foi encontrada em aproximadamente $70 \%$ da carne de boi moída, $43 \%$ da salsicha de porco e $48 \%$ da carne de aves ( BRACKET 1988).

Diversos produtos cárneos de diferentes espécies foram veículos de surtos de listeriose no período de 1989 a 1998. As carnes já foram, em alguns casos, responsáveis por surtos envolvendo a Listeria monocytogenes (DOYLE 1988; DUGGAN e PHILLIPS, 1998).

\section{- $\quad$ E. coli O 157:H7}

A designação Escherichia coli 0157:H7 surgiu inicialmente em 1982 após ter sido implicada como agente etiológico de colite hemorrágica devido a surtos ligados ao consumo de hambúrguer mal cozidos que ocorreram nos estados de Oregon e Michigan, nos Estados Unidos. Após um surto envolvendo pelo menos 600 pessoas, com a morte de quatro crianças em 1993, bem como devido ao consumo de hambúrgueres mal cozidos em uma rede de "fast food", pesquisadores dos Estados Unidos, Canadá e países da Europa conscientizaram-se da gravidade da toxinfecção causada pela bactéria Escherichia coli 0157:H7 (BELL et al., 1994). O referido surto foi o marco histórico no estudo da redução de patógenos nestes alimentos (PADHYE e DOYLE, 1994).

E. coli. O 157:H7 trata-se de uma bactéria da família Enterobacteriaceae que foi oficialmente reconhecida como importante patógeno de origem alimentar no 
início dos anos 90 . Esta bactéria provoca doenças graves como a colite hemorrágica e a síndrome urêmica hemolítica sendo o trato intestinal de ruminantes, principalmente bovinos e ovinos, o seu principal reservatório (ORMENESE et al., 1999). A maior parte das infecções causadas por $E$. coli $O$ 157:H7 tem origem em alimentos, sendo estimados de 10.000 a 20.000 casos por ano nos Estados Unidos, com mais de 150 mortes. A carne moída tem sido o principal veículo de surtos registrados nos Estados Unidos e outros países da Europa, presumindo-se que a operação de moagem transfira os microrganismos da superficie para todo interior da massa da carne, aumentando desta forma, a área de contato para o desenvolvimento bacteriano (CDC 1998).

E. coli 0157:H7 é um microrganismo emergente e vem causando enfermidades em humanos num ritmo crescente nos últimos 20 anos e ameaçando um aumento em futuro próximo (ALMEIDA et al., 1996).

Pesquisas realizadas em supermercados americanos revelaram que a $E$. coli $\mathrm{O}$ 157:H7 está presente em 1 a $25 \%$ das amostras de carne bovina, suína e de aves, sendo possível a ocorrência da contaminação no próprio ponto de venda (KNIGHT 1993).

O aquecimento adequado, e/ou o cozimento, de um alimento até uma temperatura interna de $68,3^{\circ} \mathrm{C}$, é suficiente para eliminação deste patógeno (ORMENESE et al., 1999). O controle da Escherichia coli $0157: \mathrm{H7}$ assemelha-se às de outras linhagens de Escherichia coli, sendo facilmente inativada por procedimentos normais de cocção e tratamentos térmicos adequados (MERMELSTEN 1993). 
O Departamento de Saúde do Estado de Washington recomenda que as carnes assadas e produtos de carne moída devem ser cozidos até que a temperatura atinja respectivamente 54 e $68^{\circ} \mathrm{C}$ no interior do alimento (WSDH 1997).

A presença deste microrganismo foi detectada em alimentos comercializados em via pública na cidade da Guatemala, sugerindo sua disseminação de maneira significativa no meio ambiente (ALMEIDA et al., 1996).

É importante ressaltar que as cepas de $E$. coli 0157:H7 têm dificuldade de se multiplicar, ou mesmo não se multiplicar, nas temperaturas normalmente empregadas para pesquisa de $E$. coli em alimentos: $44,5^{\circ} \mathrm{C}$ e $45,5^{\circ} \mathrm{C}$ (FRANCO e LANDGRAF, 1996).

Os patógenos emergentes têm comportamento distintos e muitos deles podem provocar seqüelas resultantes de suas potentes toxinas. Atualmente, o protótipo do surto não é mais necessariamente aquele restrito a uma instituição fechada, mas sim de casos aparentemente isolados, em diferentes cidades, estados ou mesmo países. Como determinantes da mudança deste perfil, pode-se citar fatores como: o desenvolvimento econômico e a globalização do mercado mundial, favorecendo a disseminação rápida dos microrganismos, as modificações no estilo de vida, a intensificação da urbanização, as mudanças nos hábitos alimentares bem como a intensa mobilização mundial das populações, colocando o alimento como um importante veiculador de patógenos e, consequentemente, como um problema de saúde pública (CVE 1999). 


\section{3 - Refeições a Bordo de Aeronaves}

As viagens aéreas comerciais apresentam-se de grande importância para a saúde pública por várias razões, destacando-se as condições insalubres a que estão expostos os aeronautas, o rápido transporte de agentes patogênicos e vetores de doenças, além das refeições servidas nas aeronaves estarem associadas a surtos de toxinfecções alimentares (TAUXE et al., 1987).

A preparação de alimentos para companhias aéreas não é diferente de outras formas de preparo de alimentos em outros setores. A maior diferença é a quantidade de alimentos preparados e as dificuldades de controle durante e após a produção (KELLY 1984).

A indústria do "catering" aéreo é uma atividade com riscos de problemas de origem alimentar idênticos aos de outras indústrias que fabricam refeições, sendo que alguns aspectos específicos da indústria de "catering" aéreo, geram riscos ainda maiores que os da produção tradicional de refeições. Dentre esses aspectos, destacam-se o grande volume de refeições produzidas, níveis de produção múltipla para manipuladores diferenciados, refeições preparadas com antecedência para vôos, tempo gasto entre o final da preparação e o consumo e nível de risco de clientes de diferentes origens (SOUZA 1999).

As refeições servidas em aeronaves, levam o risco de contaminar os passageiros, como também a tripulação. Requisitos de higiene na preparação de alimentos para bordo de aeronaves constituem a base para refeições seguras (ZANARDI 1998). 
O fornecimento das refeições é geralmente feito por terceiros que operam em locais especialmente adaptados, e estão situados dentro ou fora dos aeroportos. Estas empresas podem ser companhias de aviação ou companhias que têm como única função, fornecer refeições de bordo. $O$ cardápio é definido pelas empresas aéreas, considerando o tipo de alimento disponivel no local, a experiência do fornecedor $\mathrm{e}$ sua capacidade em produzir alimentos num padrão aceitável para a companhia aérea (KELLY 1984).

A refeição a bordo de aeronaves é um componente que não agrega um valor significativo ao valor da passagem e constitui um diferencial apreciado por muitos, além de ser visto pelo seu caráter nutricional e de entretenimento numa viagem de média ou longa duração. Nos vôos médios e longos, o serviço de bordo constitui um diferencial importante, pois nesses vôos, os passageiros que viajam a trabalho têm nesse atendimento a única oportunidade de refeição (BITTAR 2001).

O manuseio de grandes quantidades de alimentos revela dificuldades de higiene, pois existe a necessidade do preparo com uma certa antecedência.

A necessidade de um bom controle de temperatura durante a produção, transporte e distribuição da refeição aos passageiros e tripulação, requer o monitoramento cuidadoso durante todos os estágios e uma conscientização por parte dos empregados, da importância do controle de temperatura (KELLY 1984).

Com relação aos cardápios, muitos vôos têm o mesmo cardápio que se repetem diariamente, durante a semana para vôos nacionais e durante o mês para vôos internacionais (ZANARDI 1998). Todos os alimentos devem estar facilmente 
identificados contendo data da produção e tempo de vida, para evitar a possibilidade de alimentos vencidos serem enviados à aeronave (KELLY 1984).

Como uma medida preventiva, os comandantes das companhias aéreas devem requerer treinamento mais associado às práticas de higiene para os atendentes de vôo (WOOD 1987).

A preocupação sobre segurança alimentar não apenas cresceu em complexidade bem como o conhecimento do público viajante sobre a qualidade dos alimentos aumentou, como também o tamanho e complexidade da produção de refeições de bordo para as aeronaves (LAMBIRI et al., 1995).

Para serem evitados maiores problemas quanto à saúde da tripulação, todas as grandes companhias de aviação requerem que o piloto e o co-piloto recebam preparações diferentes. Algumas companhias de aviação requerem que os pratos que serão servidos ao piloto e ao co-piloto sejam de fontes diferentes, aplicando-se o mesmo princípio a pratos que são consumidos em terra, antes da decolagem da aeronave (WOOD 1987).

De acordo com BAILEY (1977), é recomendado que o comandante do vôo receba uma refeição diferente do co-piloto, a fim de reduzir a possibilidade de ambos consumirem alimentos contaminados por agentes patogênicos causadores de enfermidades.

Para a garantia de um bom controle de temperatura, especialistas em Saúde Pública aconselham que o chefe dos atendentes de cabine deva dispor de um termômetro calibrado para verificar a temperatura do alimento ao ser colocado no avião e antes de servi-lo (WOOD 1987). 


\section{4 - Ocorrência de Surtos em Aeronaves}

Poucos dos surtos relacionados a alimentos em vôos de aviação civil são publicados e investigados adequadamente. Relatórios documentados sobre epidemias em vôos envolvem uma larga diversidade de microrganismos, incluindo Escherichia coli, Clostridium perfringens, Salmonella, Staphylococcus aureus, Shigella, Campylobacter, Vibrio, virus e protozoários (LAMBIRI 1995).

Aproximadamente, 23 surtos de doenças relacionadas a alimentos envolvendo 120 vôos comerciais foram relatados entre 1947 e 1984, no mundo. As bactérias do gênero Salmonella foram os microrganismos mais envolvidos, causando 7 surtos, seguido por Staphylococcus (5 surtos), e as espécies Vibrios (5 surtos). Um estudo realizado com 6 mil amostras, em 40 locais que preparavam alimentos para bordo de aeronaves no mundo, em 1986, observaram o isolamento de Salmonella em aproximadamente $1 \%$ das amostras. Os isolamentos mais freqüentes foram feitos a partir dos alimentos preparados na Índia e na Indonésia. (HATAKA e ASPLUND, 1993; TAUXE 1987).

EINSENBERG (1975) relatou que 196 (57\%) de 344 passageiros e um comissário de bordo de um vôo apresentaram sintomas, a curto prazo, como náuseas, vômitos, dores abdominais e diarréia, sendo que 142 passageiros e um comissário de bordo foram hospitalizados. A investigação constatou que o presunto, servido no café da manhã a bordo da aeronave, foi o veículo do agente etiológico. Um cozinheiro com ferimentos no dedo foi o responsável pelo surto; a lesão no dedo do cozinheiro apresentou reação positiva para Staphylococcus aureus . 
Staphylococcus aureus é uma bactéria comumente responsável por surtos de toxinfecção alimentar. Vários surtos associados com refeições servidas a bordo de aeronaves foram relatados no periodo de 1948 a 1991. O maior surto ocorreu em 1973, onde 247 passageiros de vôos internacionais foram atingidos. O alimento envolvido foi um pudim, servido como sobremesa, preparado em Lisboa (TAUXE et al., 1987). Tanto alimentos frios como alimentos quentes causaram toxinfecções em aeronaves. Preparações de omelete contendo queijo e presunto foram veículos de um surto envolvendo 197 pessoas, sendo um manipulador de alimentos identificado como portador do agente incriminado (EISENBERG 1975).

Num trabalho realizado por HATAKA et al. (2000), 153 amostras de "swab" de mãos e 136 de cavidade nasal foram investigadas, a fim de verificar a presença de S. aureus . A amostragem nasal mostrou uma prevalência mais alta de $S$. aureus (29\%) do que a amostragem das mãos(9\%) e os autores concluiram que um manipulador de alimentos abrigando este patógeno foi considerado uma fonte potencial de contaminação para os alimentos.

Em um estudo realizado por BRYAN et al.(1978), em um serviço de refeições de bordo para aeronaves, foi constatado que apesar da maioria dos alimentos apresentarem boas condições sanitárias, em alguns casos houve a possibilidade de contaminação por microrganismos patogênicos e condições de sobrevivência e multiplicação dos mesmos, além de que, alguns equipamentos não conseguiam manter os alimentos em temperatura de segurança.

Um grande surto de $S$. infantis relacionado a alimentos preparados na Finlândia, em 1986, envolveu 226 pessoas, dentre as quais, 91 eram passageiros de 
aeronaves. Alimentos preparados em Palma de Mallorca foram o veículo de um surto de $S$. enteritidis que contaminou 71 passageiros em 1989 (HATAKA e ASPLUND, 1993).

Após a ocorrência de um surto envolvendo 415 passageiros em vôos, em 1991, a unidade de produção de refeições para aeronaves, envolvida neste episódio, em uma ilha grega, foi pesquisada por dois anos. LAMBIRI (1995) relatou que a concepção HACCP (Hazard Analysis and Critical Control Point / APPCC Análise de Perigos e Pontos Críticos de Controle) oferece mais oportunidades para garantir a prevenção de doenças relacionadas a alimentos.

HEDBERG et al.(1992) constataram que 21 jogadores de futebol desenvolveram shigelose, a qual foi associada ao consumo de lanches frios servidos a bordo de aeronave. A prevenção da contaminação de Shigella requer uma redução no contato direto das mãos com os alimentos, principalmente lanches frios, ou a eliminação destes itens dos cardápios para aeronaves.

EBERHART et al. (1992) relataram um surto de cólera que ocorreu em um vôo comercial da América do Sul para Los Angeles, onde 75 de 336 passageiros apresentaram a doença, sendo que 10 passageiros foram hospitalizados, com a ocorrência de um óbito. Saladas frias com frutos do mar servidas entre Lima (Peru) e Los Angeles (Califórnia) foram os veículos da toxinfecção.

No Brasil, são raras as publicações sobre toxinfecções alimentares provocadas por refeições servidas a bordo de aeronaves. 
Segundo dados do Centro de Vigilância Sanitária do Estado de São Paulo (CVS) e do Instituto de Saúde do Paraná (ISPR), não há registro de surtos de DTA envolvendo refeições a bordo de aeronaves."

De acordo com TAUXE et al. (1987), quando ocorre um surto de toxinfecção alimentar a bordo de uma aeronave, a tripulação freqüentemente é afetada, havendo o risco de pilotos do mesmo vôo adoecerem.

Segundo SOUZA (1999) não há no Brasil, legislação que associe os princípios do HACCP aos critérios de segurança, para o controle higiênico-sanitário, especificamente para a aviação.

\section{5 - Carne Bovina}

Um produto alimentar seguro, como a carne isenta de contaminantes ou adulterações, é obtido através da somatória de ações ao longo da cadeia. Tudo começa na produção de um animal sadio, livre de microrganismos e resíduos prejudiciais à saúde do homem. Normalmente os animais possuem diferentes microrganismos, alguns são patógenos específicos, outros comuns a uma série deles e até ao homem, produzindo assim as zoonoses. $\mathrm{O}$ uso de vários tipos de aditivos promotores de crescimento, como os antibióticos, cuja finalidade é combater doenças sub-clínicas nestes animais, pode evitar a transmissão de doenças para o homem, como aquelas veiculadas por Salmonella spp (SPERS e KASSOUF, 1996b).

\footnotetext{
-- Dados fornecidos pelo CVS - Centro de Vigilância Sanitária - Secretaria da Saúde do Estado de São Paulo e pelo Centro de Saneamento e Vigilância Sanitária da Secretaria de Estado da Saúde Instituto de Saúde do Paraná - ISPR
} 
As medidas de higiene e adaptação durante o transporte evitam o estresse em animais, aumentando assim a resistência deles aos contaminantes externos. A segurança alimentar continua através dos ambientes oferecidos pelos estabelecimentos onde ocorre o processo de abate dos animais e manipulação de visceras. Ela é prolongada por meios de transporte e armazenamento, nos locais de venda de carne "in natura" até os estabelecimentos de industrialização dos produtos cámeos (SPERS e KASSOUF, 1996b).

A presença de patógenos em produtos cárneos, principalmente Salmonella, constitui um sério problema para a saúde pública, uma vez que estas bactérias são causadoras de graves infecções no homem (FLORENTINO et al., 1997).

Em cada uma das fases utilizadas no processo e/ou manipulação de carnes, assim como naquelas envolvidas no processamento de diferentes produtos cárneos, devem prevalecer condições higiênicas rigorosas, para não ocasionar a contaminação microbiana do produto final, que poderia levar à sua deterioração, bem como torná-lo impróprio para o consumo (LEITÃO 1978).

Em 1990, o Departamento de Agricultura dos Estados Unidos através do Serviço de Inspeção e Segurança Alimentar (Food Safety and Inspection Service FSIS) reconheceu que certas práticas usadas durante a produção animal podem afetar a qualidade microbiológica de carcaças de animais e as operações de abate (ADAMS 1990). O uso de técnicas próprias para o manuseio dos alimentos pelos empregados das companhias produtoras e também pelos consumidores, pode reduzir a incidência de doenças relacionadas aos alimentos (ADAMS 1990; KARR 1994). 
A carne de boa qualidade microbiológica depende do abate e cortes higiênicos. Para tanto, faz-se necessário evitar a contaminação das superficies da carne fresca pelo couro ou pelo conteúdo do intestino, diretamente ou pelas mãos, roupas dos manipuladores e dos equipamentos (WHO 2002).

As carnes são os alimentos mais associados com doenças transmitidas por alimentos, apesar do agente não ser sempre identificado (GERMANO 1993, CVE 2001).

Dentre os alimentos mais envolvidos, em 53 surtos, no período de 1991 1996, na Inglaterra e País de Gales, foi observado que a carne vermelha foi o veículo de $99(32,6 \%)$ dos surtos, sendo portanto de grande importância na epidemiologia de doenças transmitidas por alimentos nestes países (PANISELLO et al., 2000).

Além da carne bovina, os alimentos que aparecem com maior freqüência nos surtos de toxinfecções alimentares são a maionese, preparação principal veiculadora de Salmonella (em segundo lugar entre os alimentos responsáveis por DTAs) e o queijo (em terceiro lugar com 23 surtos registrados) (MIGUEL 1995).

Dentre os cuidados citados por SILVA Jr (1999), com relação à prevenção de toxinfecções alimentares, o reaquecimento é a melhor medida contra os microrganismos que podem ter proliferado durante o armazenamento. Para um reaquecimento adequado é necessário que todas as partes do alimento atinjam, pelo menos, uma temperatura de $70^{\circ} \mathrm{C}$.

Foram estudadas, em amostras de bolo de carne, as condições de tempo e temperatura, qualidade sensorial e microbiológica da preparação para um serviço de comissaria. Foram encontrados, após cocção, microrganismos como Bacillus cereus, 
Clostridium sporagenes, Clostridium perfringens, Sthaphylococcus aureus e $S$. epidermidis. Segundo os autores, a carne cozida deve ser processada a temperaturas relativamente altas. A presença de bactérias do gênero Staphylococcus, indica a contaminação durante ou após o processamento. No armazenamento em refrigeradores, pode ocorrer a contaminação por bolores, principalmente se o alimento estiver desprotegido. Devido à existência de vários gêneros de patógenos conhecidos, há um potencial perigo em Saúde Pública, quando o alimento não é manipulado adequadamente (CREMER e CHIPLEY, 1979).

Preparações com carne bovina foram avaliadas no sentido de verificar o binômio tempo/temperatura, no preparo de refeições de bordo. Foi constatado que, no processo de cocção, $86 \%$ das amostras coletadas apresentaram-se fora dos critérios estabelecidos para a inativação de células vegetativas de bactérias. Os desvios encontrados principalmente nas etapas de cocção e transporte até a aeronave, podem eventualmente comprometer a segurança do alimento e consequentemente a saúde do consumidor (ZANARDI 1998).

Num trabalho realizado por BELTRAN et al.(1999) foi constatado que as amostras à base de produtos cárneos analisadas encontravam-se de acordo com a legislação brasileira, sugerindo que boas práticas de higiene foram adotadas durante o preparo dos alimentos a serem servidos em aeronaves. 


\section{6 - Testes Rápidos para Deteç̧ão de Microrganismos}

Os métodos rápidos surgiram a partir da década de 70 , a fim de reduzir o tempo de análise no Laboratório de Microbiologia, aumentando a produtividade do trabalho realizado (HAJDENWURCEL 1998). Além desse objetivos, esses métodos visam também a simplificação do trabalho e a redução de custos, aliando-se a essas vantagens, maior sensibilidade e especificidade que os métodos convencionais (FRANCO 1999).

Nos últimos anos vêm sendo desenvolvidos diversos métodos de análise microbiológica de alimentos, muitos dos quais encontram-se aprovados ou em estágio final de aprovação oficial por órgãos reguladores internacionais. A adoção oficial de novos métodos no Brasil, é regulamentada pela Portaria $\mathrm{N}^{\circ} 001 / 87$ da Divisão Nacional de Vigilância Sanitária de Alimentos (DINAL), que a condicionam à inclusão no Bacteriological Analytical Manual (BAM) editado pela Food and Drug Administration (FDA), ou no Compedium of Methods for the Microbiological Examination of Foods, editado pela American Public Health Association (APHA). Estas duas publicações compilam a metodologia da análise microbiológica aprovada pela Association of Official Analytical Chemists (AOAC) (SILVA et al., 1997; AOAC 2000; APHA 2000).

Dentre os novos métodos para a detecção de microrganismos de importância em alimentos, destacam-se: 


\section{- PETRIFILM Coliformes e Escherichia coli (3M)}

Como método alternativo para contagem de microrganismos em alimentos merecem destaque as placas de Petrifilm. Estas placas constituem-se de cartões de papel quadriculado revestido de polietileno, recobertos com nutrientes e agentes geleificados desidratados (FRANCO 1999).

O Petrilfim permite substituir as placas e tubos de vidro para meios de cultura com ágar e outros meios líquidos até então empregados.

As placas Petrifilm são compostas por dois filmes:

- um filme superior em polipropileno, recoberto internamente com um adesivo que contém indicador e géis hidrossolúveis a frio;

- um filme inferior em papel quadriculado revestido por polietileno, recoberto por nutrientes e géis hidrossolúveis.

Neste meio, as culturas são replicadas para formar colônias como no método tradicional.

A contagem de coliformes totais e E.coli em amostras de alimentos em geral, por testes rápidos apresenta vantagens como inoculação rápida e simples, diluições facilitadas com o uso de pipetadores de diluição adaptados para o produto, pouco espaço para incubação, não exigência de equipamentos para leitura e confirmação de E. coli (SILVA et al., 1997). Outras vantagens descritas pelo fabricante seriam redução das etapas de análise para três: inoculação, incubação e leitura; padronização da técnica, pois as placas são uniformes; diminuição da ocorrência de problemas no laboratório durante o preparo e esterilização de meios de cultura; redução de desperdicios de meios de cultura; leitura com maior segurança; redução de perdas e 
riscos de acidentes com vidros quebrados; maior rapidez nas análises de coliformes e E. coli; redução de estoques de materiais de laboratório como placas de Petri, tubos, recipientes para preparar e armazenar meios de cultura; placas de tamanho e espessura reduzidas ocupando pouco espaço; estufas menores, diminuindo o gasto com energia elétrica e redução do número de esterilizações em autoclave para esterilizações de vidrarias e meios de cultura (3M 2000).

As placas para contagem de coliformes totais baseiam-se na contagem de colônias vermelhas coradas por um indicador, sempre acompanhadas por bolhas de gás. Os nutrientes presentes são os mesmos do Ágar Violeta Bile Vermelho Fenol da metodologia tradicional. Os coliformes produzem gás pela fermentação da lactose; 0 gás produzido fica ao redor das colônias retido entre os filmes da placa Petrifilm, permitindo assim, a sua diferenciação de outras bactérias Gram negativas que possam estar presentes (3M 2000).

A interpretação das placas Petrifilm para contagem de coliformes é simples. Um corante indicador vermelho dá cor às colônias e o filme plástico retém o gás produzido pelos coliformes. Bactérias do grupo coliformes produzem colônias vermelhas associadas a bolhas de gás e as demais bactérias produzem colônias vermelhas que não estão associadas a bolhas de gás (3M 2000).

Para a realização da contagem das colônias de E.coli nas placas Petrifilm, deve-se contar as colônias azuis associadas às bolhas de gás. E. coli produz glicuronidase que reage com o corante indicador na placa, formando um precipitado azul em torno da colônia (3M 2000). 
As placas para contagem de $E$. coli possuem as mesmas características das placas para coliformes totais, complementada por uma ação enzimática com glicuronidase, formando um precipitado azul quando esta colônia for uma E. coli. Nesta placa, contam-se coliformes totais como sendo as colônias vermelhas mais as colônias azuis, ambas associadas a bolhas de gás (3M 2000).

\section{- REVEAL ${ }^{\mathrm{R}}$ para Salmonella (Neogen)}

O sistema Reveal para Salmonella combina o imunoensaio ELISA (Enzymelinked immunosorbent assay) com o poder da cromatografia, propiciando resultado rápido e preciso. $O$ teste é designado para uma larga gama de amostras. Detecta níveis de Salmonella spp presentes após 20 horas da coleta da amostra. 0 meio REVIVE é uma formulação patenteada para reconhecimento de Salmonella spp em alimentos. $\mathbf{O}$ mesmo possibilita a recuperação de células injuriadas, estressadas e em meio com condições de Oxigênio reduzido. Ele apresenta vantagens como a utilização de mecanismo visual de leitura com resultados consistentes, utilização de equipamentos básicos de laboratório, possuindo alto desempenho tendo sido testado e validado pela AOAC (NEOGEN 2000b).

\section{- KIT STAPHTECT DRY SPOT DR 100M - OXOID}

OXOID KIT STAPHTECT DRY SPOT DR 100M é um teste rápido onde é empregada a técnica de aglutinação de látex para a identificação de Staphylococcus aureus, através da detecção de Fator "Clumping" e Proteína A, características desse patógeno, e Polissacarídeo Capsular (encontrado em cepas de $S$. aureus resistentes à 
Meticilina - MRSA). Recentemente, foi descrito que a Proteina A é encontrada na parede celular de $95 \%$ das cepas de $S$. aureus de interesse humano (OXOID 2000).

\section{- Listeria RAPID TEST - OXOID}

OXOID LISTERIA RAPID TEST é um kit idealizado para deteç̧ão de Listeria spp em alimentos e amostras ambientais em 43 horas, associando culturas em caldos de enriquecimento a um imunoensaio de fase sólida (TEST-PACK). Após duas incubações em caldos de enriquecimento, uma amostra de $2 \mathrm{~mL}$ é aquecida por 20 minutos a $80^{\circ} \mathrm{C}$ e $135 \mu \mathrm{L}$ desse é extraído e adicionado à placa teste. Nessa placa encontram-se anticorpos monoclonais anti-flagelar B impregnados por partículas de látex azul (cavidade teste), anticorpos monoclonais anti-flagelar B imobilizados (cavidade resultado) e anticorpos policlonais anti-anticorpo flagelar imobilizados. $\mathrm{Na}$ presença do antígeno flagelar B, este irá fixar-se aos anticorpos específicos, movendo-se para a cavidade resultado, formando o clássico sanduíche (anticorpo/antígeno/anticorpo), onde será visualizada uma linha azul. Os anticorpos restantes continuam migrando para a cavidade controle, fixando-se aos anticorpos policlonais anti-anticorpo flagelar B, formando outra linha azul (controle de prova) (OXOID 2000).

\section{- REVEAL ${ }^{\mathrm{R}}$ para $E$ coli 0157:H7 (Neogen)}

O sistema Reveal para E.coli 0157:H7 é um teste que possibilita resultado em apenas 8 horas de enriquecimento da amostra. Seu uso fácil requer pouco investimento em equipamentos e treinamento, incorporando efetivos e precisos 
resultados em seu programa de controle de patógenos. 0 sistema baseia-se em reações antígeno - anticorpo, onde sempre haverá uma linha vermelha na letra C (controle) e somente aparecerá na letra $\mathrm{T}$ (teste) se o teste for positivo. Este teste apresenta como vantagens a utilização de mecanismo visual de leitura com precisão nos resultados e equipamentos básicos de laboratório (NEOGEN 2000a). 


\section{2 - JUSTIFICATIVA}

De acordo com dados obtidos sobre a avaliação do sistema HACCP, em que os fluxogramas de preparações com carne bovina em um serviço de refeições de bordo demonstraram que a etapa de cocção foi a que apresentou maior diferença no que se refere aos critérios de segurança, ou seja, tempo e temperatura abaixo dos valores estabelecidos em $86 \%$ das amostra analisadas, onde pôde-se constatar que as preparações comprometeriam a segurança do alimento bem como representar perigo à saúde do consumidor (ZANARDI 1998).

Devido aos perigos que podem ocorrer durante a preparação de alimentos em um serviço de refeições de bordo e às constantes mudanças de temperatura durante todo o processo de preparação das refeições, o controle higiênico-sanitário dos alimentos deve ser realizado de forma que não permita a sobrevivência bem como a multiplicação dos microrganismos.

Atualmente, há um maior movimento internacional de alimentos e pessoas, sendo o turismo uma das maiores indústrias em crescimento no mundo e a cada ano, mais pessoas viajam, ficando mais expostas ao perigo, no que diz respeito a doenças de origem alimentar (OMS 2002).

A qualidade higiênico-sanitária das preparações se torna fundamental para este tipo de refeição, pois a contaminação pode afetar diretamente a segurança aérea. Paralelamente a avaliação das condições microbiológicas pode fornecer dados sobre o grau de comprometimento das preparações. 
A análise de coliformes totais e Escherichia coli se faz necessária, pois a presença destes microrganismos indicadores pode comprometer a qualidade e a segurança do produto, uma vez que indicam aumento da probabilidade da presença de patógenos (JAY 2000).

A deteç̧ão de Salmonella spp e Staphylococcus aureus, justifica-se pela relevância desses microrganismos em saúde pública, por estarem os mesmos associados freqüentemente a surtos de doenças transmitidas por alimentos.

Devido à severidade das infecções por Listeria spp e Listeria monocytogenes, microrganismos patogênicos que se multiplicam em temperatura de refrigeração, podendo comprometer, portanto, a qualidade das refeições servidas a bordo das aeronaves e por apresentarem taxa de mortalidade em torno de $50 \%$, sua pesquisa se torna importante para este tipo de refeição.

Quanto a $E$. coli $0157: \mathrm{H7}$, a verificação de sua presença no alimento se faz relevante, por se tratar de uma bactéria emergente e causadora de doenças graves como a colite hemorrágica e a síndrome urêmica hemolitica.

As carnes são os alimentos mais freqüentemente associados com doenças transmitidas por alimentos, necessitando portanto de um controle mais efetivo nas etapas de produção, a fim de garantir sua qualidade microbiológica. 


\section{3 - OBJETIVOS}

\section{1 - OBJETIVO GERAL}

Avaliar as condições microbiológicas de preparações alimentícias com carne bovina, servidas a bordo de aeronaves.

\section{2 - OBJETIVOS ESPECÍFICOS}

- Determinar a contagem de microrganismos indicadores de qualidade higiênicosanitária: coliformes totais e Escherichia coli;

- Verificar a presença ou ausência dos microrganismos patogênicos :

Staphylococcus aureus, Salmonella spp, E.coli 0157:H7 e Listeria spp;

- Avaliar a temperatura das preparações e verificar sua possível relação com a qualidade microbiológica;

- Avaliar o perigo que as preparações com carne bovina servidas a bordo de aeronaves oferecem ao consumidor 


\section{MATERIAL E MÉTODOS}

\section{1 - Objeto de pesquisa}

Considerou-se como objeto de pesquisa as preparações culinárias à base de carne bovina disponíveis no periodo da coleta, servidas a bordo de aeronaves, tanto para vôos nacionais como para vôos internacionais, sendo elas :

- Brochete de filé

- Escalope de filé

- Filé à parmeggianna

- Goulash

- Lagarto assado fatiado

- Rosbife

- Tornedor de filé mignon

As preparações encontravam-se acondicionadas em embalagens prontas para consumo, com seus respectivos acompanhamentos e armazenadas sob refrigeração.

\section{2 - Local da coleta}

A coleta das amostras foi realizada em um Serviço de Refeições de Bordo, localizado em um dos aeroportos do Estado de São Paulo.

\section{3 - Período da coleta}

As amostras foram coletadas no periodo de abril a junho de 2001. 


\section{4 - Variáveis estudadas}

\subsection{1 -Variáveis extrínsecas dos alimentos}

- Tipo de preparação culinária: Os diversos tipos de preparações culinárias encontram-se descritos no glossário (ANEXO)

- Características da preparação quanto ao ponto de cocção: Essas características foram classificadas por meio de inspeção visual, em função da cor vermelha, rosa ou marrom apresentada internamente pelas preparações; muito mal passadas, mal passadas e bem passadas, respectivamente, conforme Figura 4.1.

- Tempo de embalagem: Foram utilizadas preparações embaladas no próprio dia da coleta e no dia anterior.

- Temperatura das amostras: A determinação da temperatura foi feita na superfície da preparação.

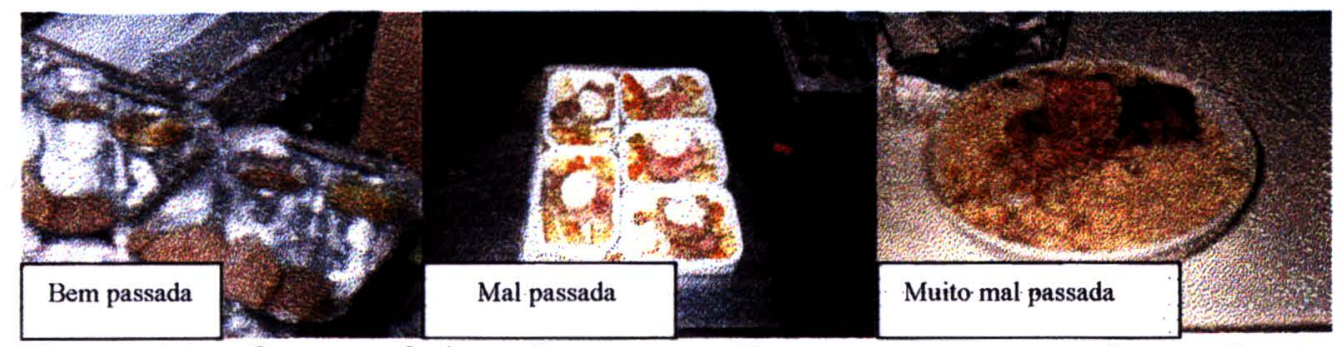

Figura 4.1 - Características da preparação quanto ao ponto de coç̧ão

\subsection{2 - Variáveis Microbiológicas}

- Coliformes totais

- Escherichia coli

- Staphylococcus aureus 
- Salmonella spp

- Listeria spp

- E. coli O $157: \mathrm{H} 7$

\section{5 - Coleta e preparo das amostras para análise}

As amostras foram coletadas em suas embalagens originais, prontas para embarque a bordo das aeronaves e, acondicionadas em recipiente isotérmico contendo gelo, para a manutenção da temperatura inicial durante o transporte até o laboratório de análise.

Para as refeições de bordo é utilizado o sistema de identificação por meio de etiquetas coloridas, conforme a recomendação do Ministério da Saúde e das Companhias Aéreas com vôos no Brasil. Essas etiquetas seguem o código universal de cores, para comissaria de bordo, que atribui para cada dia da semana uma cor característica: domingo - vermelho, segunda-feira - verde escuro, terça-feira marrom, quarta-feira - amarelo, quinta-feira - laranja, sexta-feira - verde claro e sábado -azul.

Para as amostras analisadas, no presente estudo, foram utilizados como critério para tempo de embalagem, o dia referente à análise microbiológica (no dia da análise) ou o dia anterior (24 horas). Contudo, as preparações são feitas com antecedência de 24 a 48 horas e etiquetadas, indicando o dia da semana em que o alimento foi preparado. Na etapa posterior, as preparações são armazenadas sob refrigeração, podendo haver na câmara frigorífica, preparações de dias diferentes. 0 
sistema de etiquetas coloridas permite o controle do prazo de validade identificando as preparações que devem ser primeiro utilizadas.

A temperatura das preparações foi mensurada na superfície das mesmas utilizando-se termômetro digital RYTEC MINITEMP MT4, com mira laser, faixa de temperatura de $-18^{\circ} \mathrm{C}$ a $260^{\circ} \mathrm{C}$. A análise microbiológica ocorreu no periodo máximo de 3 horas a partir da coleta das amostras, as quais foram mantidas sob refrigeração até o início da análise.

\section{6 - Métodos de análise laboratorial}

As análises microbiológicas das amostras foram realizadas no Laboratório de Saúde Pública, do Departamento de Prática em Saúde Pública, da Faculdade de Saúde Pública - USP, pela própria pesquisadora.

\subsection{1 - Preparo das amostras}

Foram pesadas assepticamente $25 \mathrm{~g}$ da amostra, para cada tipo de teste e trituradas em liquidificador.

\subsection{2 - Procedimento para as análises microbiológicas}

As análises microbiológicas foram realizadas de acordo com os padrões para testes rápidos reconhecidos pela AOAC (Association of Official Analytical Chemists) - Métodos de Validação e Procedimentos (AOAC 2002). 


\section{a) Contagem de coliformes totais e Escherichia coli}

Para a contagem de coliformes totais e E.coli foram utilizadas Placas Petrifilm $^{\mathrm{TM}}(3 \mathrm{M}-6404)$.

Uma alíquota de $25 \mathrm{~g}$ de cada amostra triturada foi diluída em $225 \mathrm{~mL}$ de água peptonada estéril (AP 0,1\%) e homogeneizada.

As placas de Petrifilm foram colocadas sobre uma superficie totalmente plana e, levantando-se o filme superior, foi inoculado $1 \mathrm{~mL}$ da amostra no centro do filme inferior, perpendicularmente à placa. Posteriormente, soltou-se o filme superior sobre a amostra diluída, evitando a formação de bolhas de ar, distribuindo uniformemente a amostra pela placa e exercendo uma leve pressão sobre o centro do difusor plástico.

As amostras foram mantidas em estufa a $37^{\circ} \mathrm{C}$ por 24 horas e, posteriormente, realizada a leitura. Foram contadas as colônias vermelhas com produção de gás indicativas da presença de coliformes totais e as colônias azuis com formação de gás indicativas da presença de E.coli, conforme Figura 4.2 e 4.3.

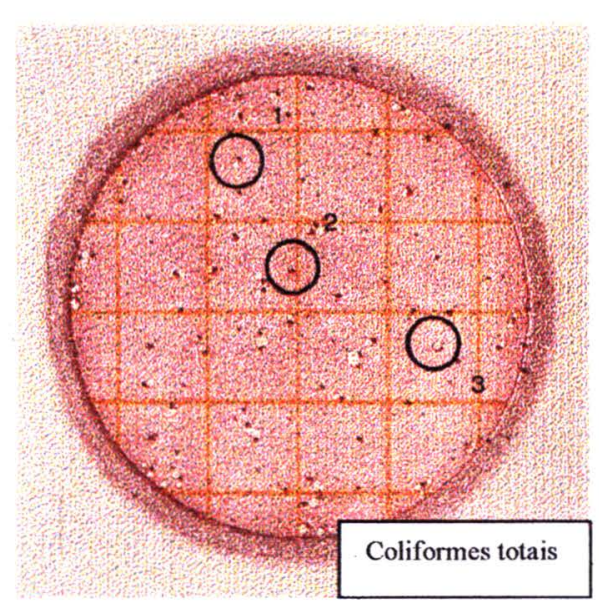

Figura 4.2 - Placa para contagem de coliformes totais - Petrifilm 3M

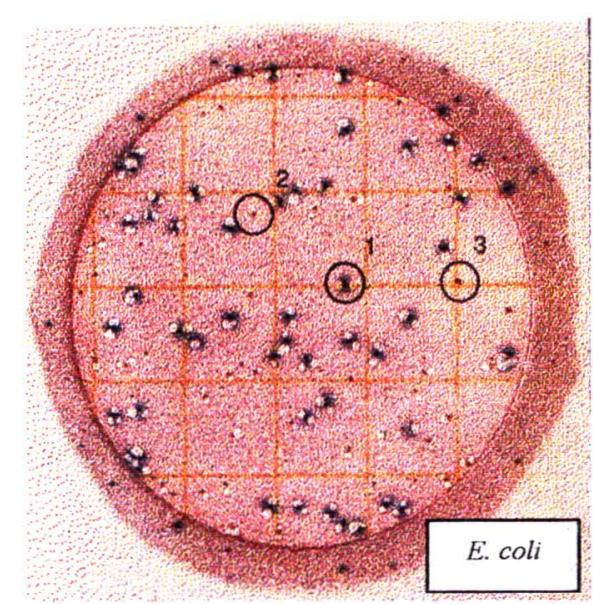

Figura 4.3 - Placa para contagem de $E$ coli - Petrifilm 3M 
A Figura 4.2 ilustra os coliformes que produzem colônias vermelhas associadas a bolhas de gás. Os círculos 1,2 e 3 mostram como $o$ aspecto das bolhas de gás pode variar. Algumas vezes, o gás causa o rompimento da colônia (círculo 3).

A Figura 4.3 ilustra as colônias de E. coli, representadas pelas colônias azuis associadas a bolhas de gás (círculo 1). $\mathrm{O}$ círculo 2 representa coliformes não E.coli, por formarem colônias vermelhas associadas a bolhas de gás. $\mathrm{O}$ círculo 3 representa colônias não-coliformes, são vermelhas mas não estão associadas a bolhas de gás.

\section{b) Presença de colônias de Staphylococcus aureus}

Uma alíquota de $25 \mathrm{~g}$ de cada amostra triturada foi diluída em $225 \mathrm{~mL}$ de água peptonada estéril (AP $0,1 \%$ ), homogeneizada e posteriormente diluída às concentrações $10^{-2}$ e $10^{-3}$.

Uma aliquota de $0,1 \mathrm{~mL}$ de cada diluição foi colocada na superficie de placas do meio de cultura Baird Parker (OXOID) adicionado de 5\% de solução de gema de ovo - telurito de potássio $\left(\mathrm{K}_{2} \mathrm{TeO}_{3}\right.$ - OXOID), espalhando-se bem com movimentos circulares, utilizando-se uma alça de Drigalsky, até a placa absorver todo o líquido. Após aproximadamente um minuto, as placas foram invertidas e incubadas à $37^{\circ} \mathrm{C}$ por 24 a 48 horas.

As colônias características, ou seja, aquelas pequenas com coloração cinza escuro a preta, convexas, lisas, redondas com halo duplo, sendo um opaco e outro transparente, foram transferidas para o KIT STAPHYTECT PLUS DRY SPOT DR $100 \mathrm{M}$ (OXOID), para sua confirmação. 
Para a confirmação das colônias isoladas adicionou-se uma gota de solução salina $(0,9 \%)$ em cada uma das áreas de prova e de controle do teste, conforme Figura 4.4. Com uma alça estéril, foram selecionadas cinco colônias de tamanho médio, as quais foram emulsionadas com a gota de solução salina, misturando-se completamente a suspensão com o látex e cobrindo-se toda a área de reação. Utilizando-se outra alça, procedeu-se da mesma maneira com o Látex Controle, realizando movimentos circulares por cerca de 20 segundos e observou-se a formação ou não de aglutinação, sob condições normais de luz.

A aglutinação das partículas de látex em até 20 segundos, indica a presença de $S$. aureus.

A ausência de $S$. aureus foi indicada pela falta de aglutinação e permanência da suspensão azul nas áreas da reação, em tempo máximo de 20 segundos. As reações que ocorreram após 20 segundos foram ignoradas.
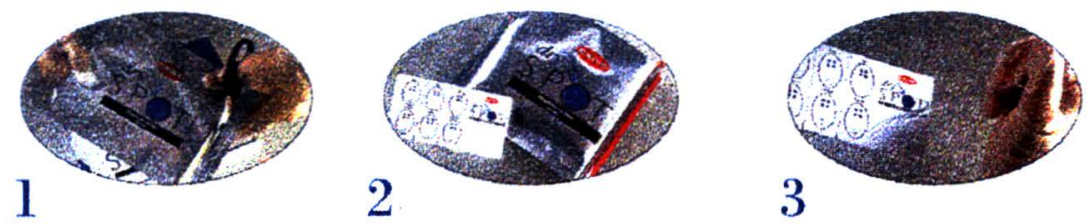

3
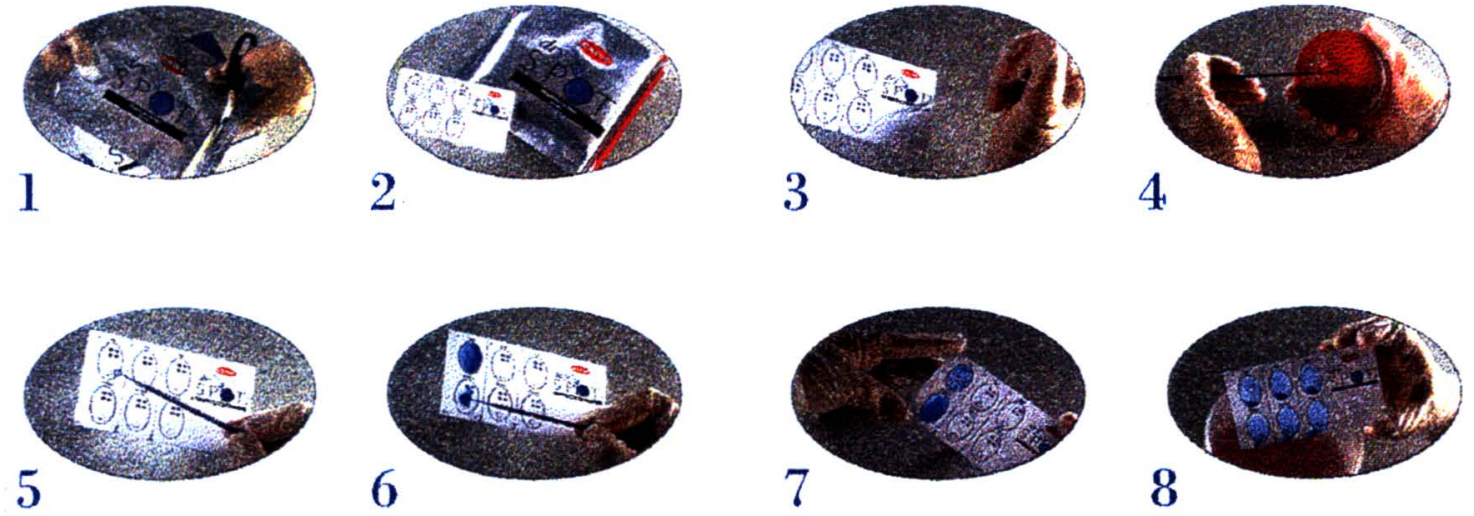

Figura 4.4 - Confirmação da presença de Staphylococcus aureus utilizando-se o KIT STAPHYTECT PLUS DRY SPOT DR 100M (OXOID), 


\section{c) Presença de Salmonella spp}

Para a verificação da presença de Salmonella spp foi utilizado o Teste rápido REVEAL $^{\mathrm{R}}$ (NEOGEN) para Salmonella.

O meio de pré-enriquecimento REVIVE foi re-hidratado com $200 \mathrm{~mL}$ de água destilada estéril, adicionado de $25 \mathrm{~g}$ da amostra triturada e após a homogeneização incubado por 4 horas a $37^{\circ} \mathrm{C}$. Após este período, o meio RAPPAPORT foi re-hidratado com $200 \mathrm{~mL}$ de água destilada estéril e adicionado ao conteúdo do caldo de pré-enriquecimento. As amostras foram incubadas a $42^{\circ} \mathrm{C}$ durante 16 horas. Uma alíquota de $135 \mu \mathrm{L}$ da amostra foi retirada com pipeta, que acompanha o kit, e adicionada à cavidade correspondente à amostra, no suporte plástico fornecido junto com o sistema, conforme Figura 4.5. A leitura foi realizada após 20 minutos.

O resultado positivo foi considerado pela presença de uma linha vermelho escuro nas cavidades relativas ao teste (T) e ao controle (C). A presença de linha vermelho escuro apenas na cavidade relativa ao controle (C), foi considerada como resultado negativo.

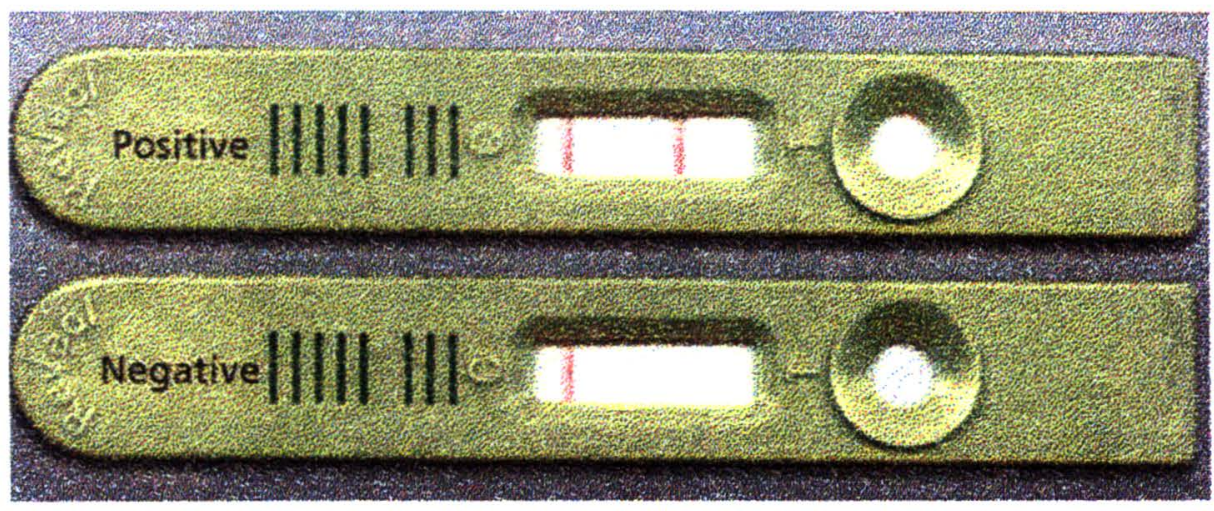

Figura 4.5 - Verificação da presença de Salmonella spp utilizando-se o Teste rápido REVEAL ${ }^{\mathrm{R}}$ (NEOGEN) para Salmonella. 


\section{d) Presença de Listeria spp}

Para a verificação da presença de Listeria spp foi utilizado o sistema LISTERIA RAPID TEST (OXOID).

Foram utilizados dois enriquecimentos, sendo que no primeiro, uma aliquota de $25 \mathrm{~g}$ da amostra foi homogeneizada em $225 \mathrm{~mL}$ de Caldo Fraser Oxoid (CM 0895), adicionando-se o suplemento (SRO 166). As amostras foram então incubadas a $\cdot 30^{\circ} \mathrm{C}$ por 21 horas. Para o segundo enriquecimento, foi retirado $0,1 \mathrm{~mL}$ do enriquecimento inicial e adicionado a $10 \mathrm{~mL}$ do caldo BLEB (Oxoid-CM 0897) contendo um novo suplemento (SR 0141) e as amostras foram incubadas novamente $30^{\circ} \mathrm{C}$ por 21 horas.

Após o periodo de incubação, foram transferidos $2 \mathrm{~mL}$ da superficie de crescimento para um novo tubo de ensaio. Este tubo foi levado ao banho-maria, numa temperatura de $80^{\circ} \mathrm{C}$ durante 20 minutos. Após esta etapa e ao atingir a temperatura ambiente, uma alíquota de $135 \mu \mathrm{L}$ foi retirada e adicionada na cavidade correspondente à amostra no suporte plástico fornecido junto com o sistema, conforme Figura 4.6. A leitura foi realizada após 20 minutos, sendo considerado resultado positivo a presença de uma linha azul nas cavidades relativas ao teste $(\mathrm{T})$ e ao controle (C). O resultado foi considerado negativo quando apresentou linha azul apenas na cavidade relativa ao controle (C). 


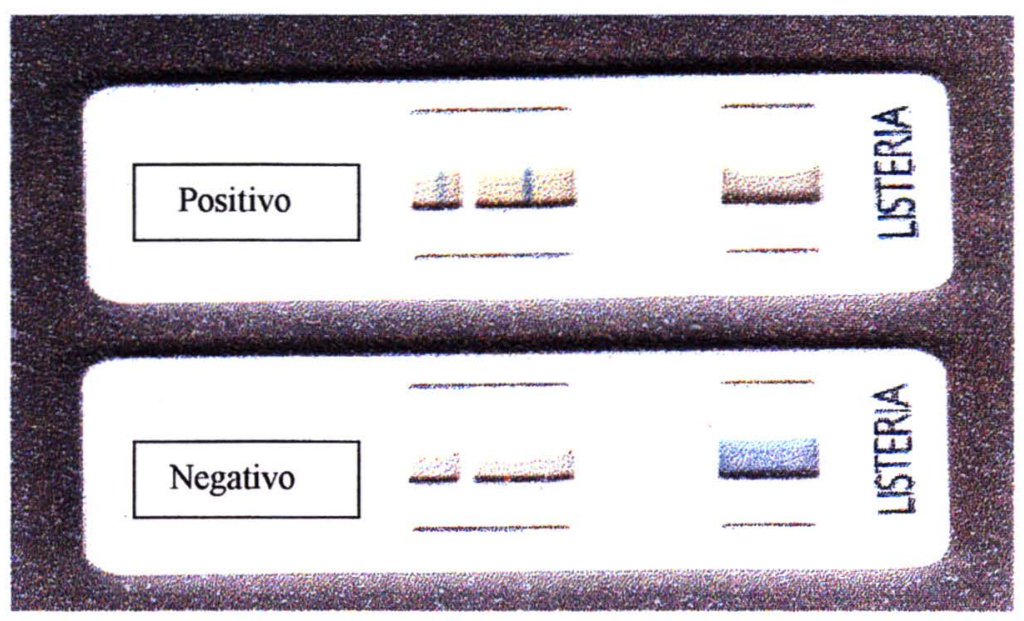

Figura 4.6 - Verificação da presença de Listeria spp utilizando Sistema LISTERIA RAPID TEST (OXOID)

Complementando a pesquisa, as cepas de Listeria spp, foram isoladas e encaminhadas ao Instituto Adolfo Lutz- São Paulo, S.P. para a sua identificação.

\section{e) Presença de E.coli 0:157 H7}

Para a verificação da presença de E.coli $0: 157$ H7, foi utilizado o Teste rápido REVEAL $^{\mathrm{R}}$ (NEOGEN) para E. coli $\mathrm{O}$ 157:H7.

O meio de cultura Reveal 8 foi re-hidratado com $225 \mathrm{~mL}$ de água destilada estéril e adicionado de $25 \mathrm{~g}$ da amostra, sendo incubado a $42^{\circ} \mathrm{C}$ por 8 horas. Após este período, transferiu-se $10 \mathrm{~mL}$ deste caldo para um tubo de ensaio, aquecendo-se em banho-maria à $100^{\circ} \mathrm{C}$ durante 10 minutos. Uma alíquota de $135 \mu \mathrm{L}$ da amostra, previamente aquecida, foi retirada com pipeta que acompanha o kit e colocada na cavidade correspondente à amostra no suporte plástico fornecido junto com o sistema, conforme Figura 4.7. Após 20 minutos, foi realizada a leitura, considerando-se como resultado positivo a presença de linha vermelho escuro na 
cavidade relativa ao teste (T) e ao controle (C). A presença de uma linha vermelho escuro apenas na cavidade relativa ao controle (C), foi considerado como resultado negativo.

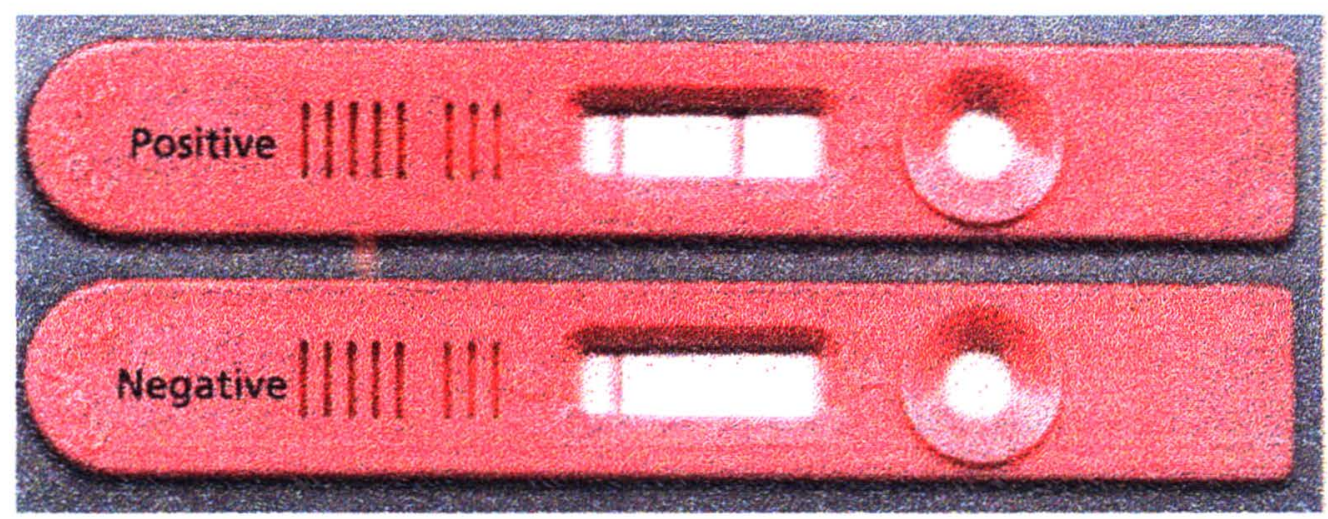

Figura 4.7 - Verificação da presença de $E$. coli 0157:H7 utilizando-se o teste rápido REVEAL ${ }^{\mathrm{R}}$ (NEOGEN) para $E$. coli $O$ 157:H7.

\section{7 - Padrão microbiológico utilizado}

Foi utilizada a Resolução RDC n ${ }^{\circ} 12$, de 02/01/01, da Agência Nacional de Vigilância Sanitária - Ministério da Saúde para uma amostra indicativa (Brasil 2001). As preparações foram enquadradas como pratos prontos para consumo, na categoria à base de carnes, pescados, ovos e similares cozidos. 
Quadro 4.1 - Padrões microbiológicos sanitários para alimentos (pratos prontos para consumo) referente à tolerância para amostra indicativa segundo ANVISA ( Resolução RDC n⿳ 12 de 02/01/01)

\begin{tabular}{|l|c|c|c|}
\hline \multicolumn{1}{|c|}{ Categoria } & $\begin{array}{c}\text { Coliformes } \\
\mathbf{4 5}^{\circ} \mathbf{C} / \mathbf{g}^{*}\end{array}$ & $\begin{array}{c}\text { Estafilococos } \\
\text { coagulase } \\
\text { positiva/g }\end{array}$ & Salmonelia sp/25 g \\
\hline $\begin{array}{l}\text { A base de carnes, } \\
\text { pescados, ovos e } \\
\text { similares }\end{array}$ & $2 \times 10$ & $1 \times 10^{3}$ & Ausência \\
\hline
\end{tabular}

Fonte : Brasil ( Resolução RDC n ${ }^{\circ} 12$ de 02/01/01)

*A denominação "coliformes a $45^{\circ} \mathrm{C}$ " é eqüivalente a denominação de " coliformes de origem fecal" e de "coliformes termotolerantes".

**A enumeração de estafilococos coagulase positiva tem por objetivo substituir a determinação de Staphylococcus aureus.

\section{8 - Análise estatística dos resultados}

Para a análise estatística das variáveis em estudo foi utilizado o programa SPSS 10.0 para Windows. 


\section{5 - RESULTADOS}

\section{1-Perfil das Amostras}

Foram coletadas 50 amostras destinadas a vôos nacionais e internacionais, durante o período de abril a junho de 2001. O destino dos vôos não foi considerado como uma variável na análise pois na maioria dos casos, as preparações para os dois tipos de vôo eram feitas da mesma maneira e com os mesmos critérios, diferenciando-se apenas quanto ao acompanhamento ou tipo de embalagem.

As cinqüenta amostras coletadas encontravam-se assim distribuídas: brochete de filé (2), escalope de filé (14), filé à parmeggiana (2), goulash (5), lagarto assado fatiado (3), rosbife (4) e tornedor de filé (20), conforme Gráfico 5.1. Estas preparações estão ilustradas nas Figuras 5.1a, 5.1b, 5.1c e 5.2.

O número das amostras coletadas nas diversas preparações foi diferente por estarem relacionadas, ao cardápio disponível no periodo, à operacionalização do serviço e ao número de passageiros a bordo das aeronaves.

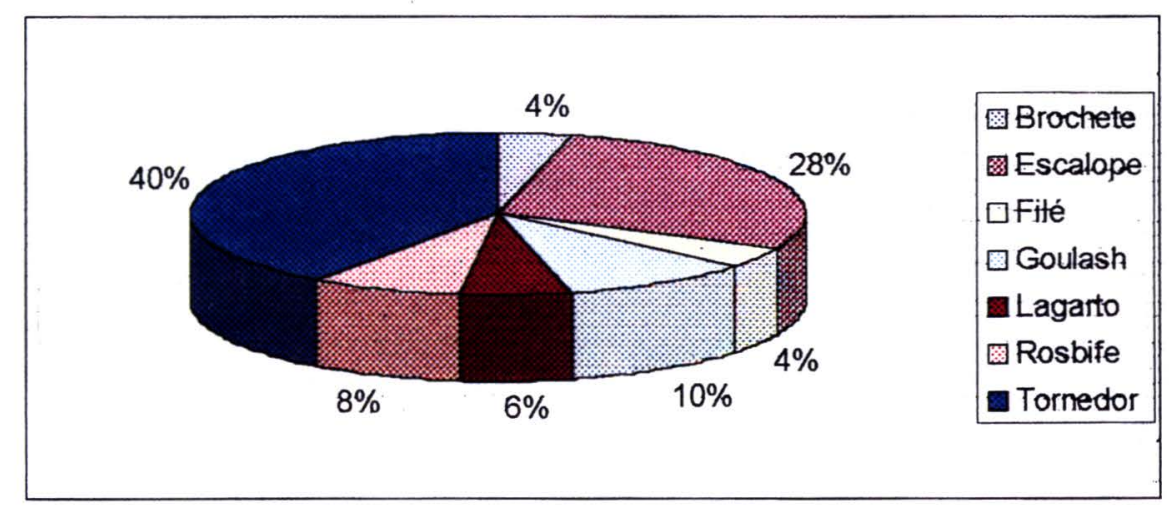

Gráfico 5.1-Distribuição das amostras quanto ao tipo de preparação 

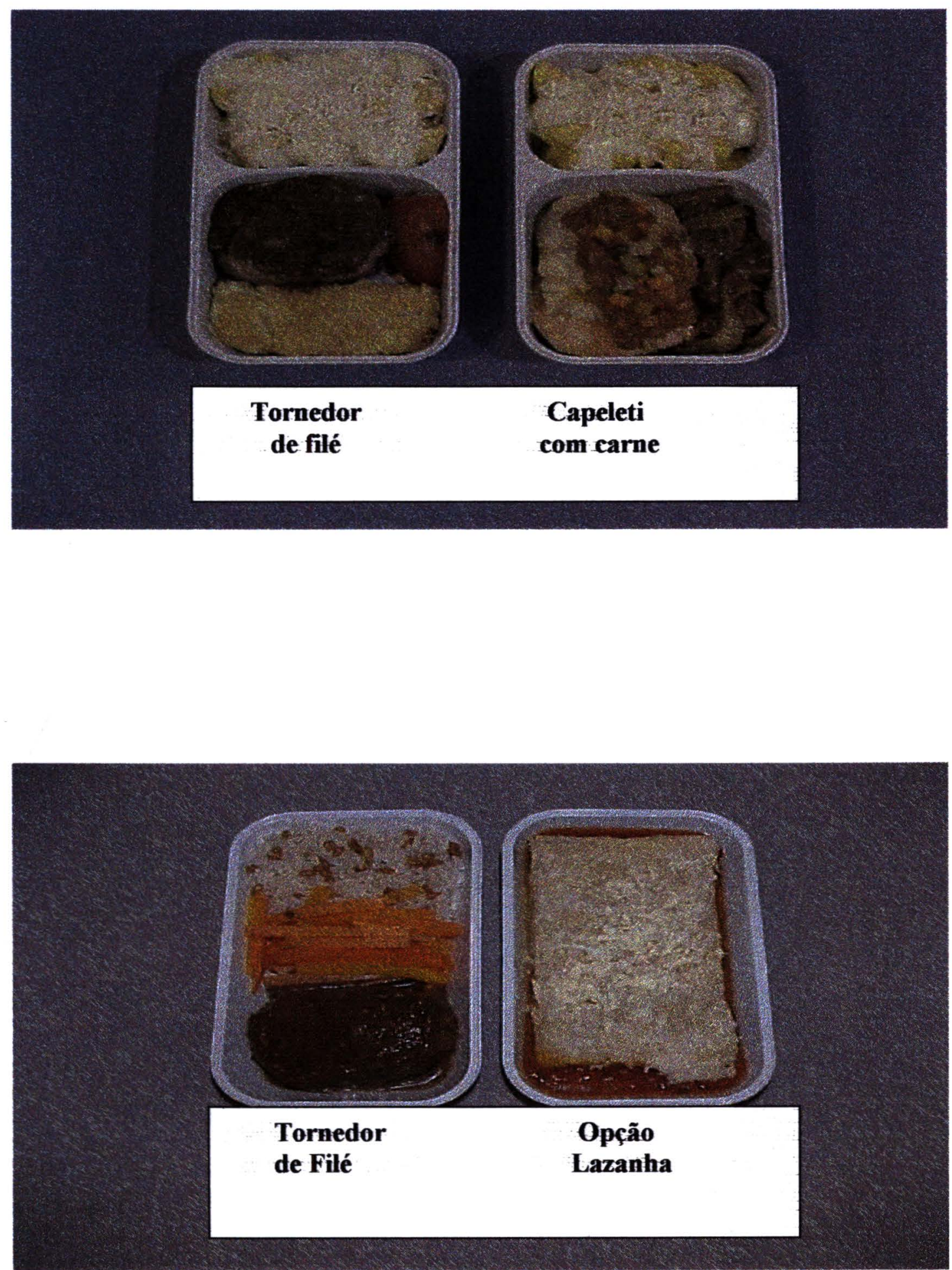

Figura 5.1a : Preparações culinárias à base de carne bovina e suas opções 

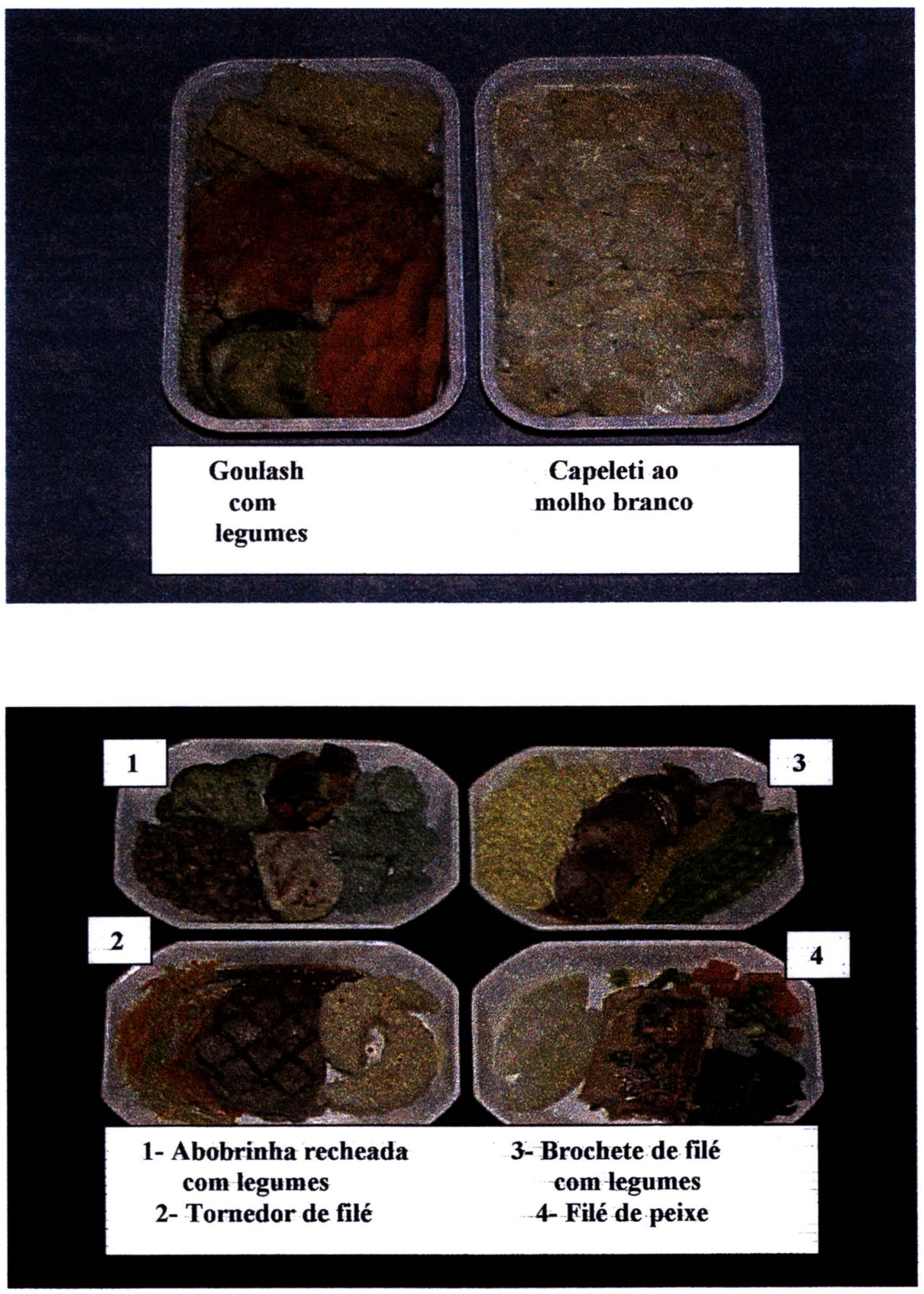

Figura 5.1b : Preparações culinárias à base de carne bovina e suas opções 


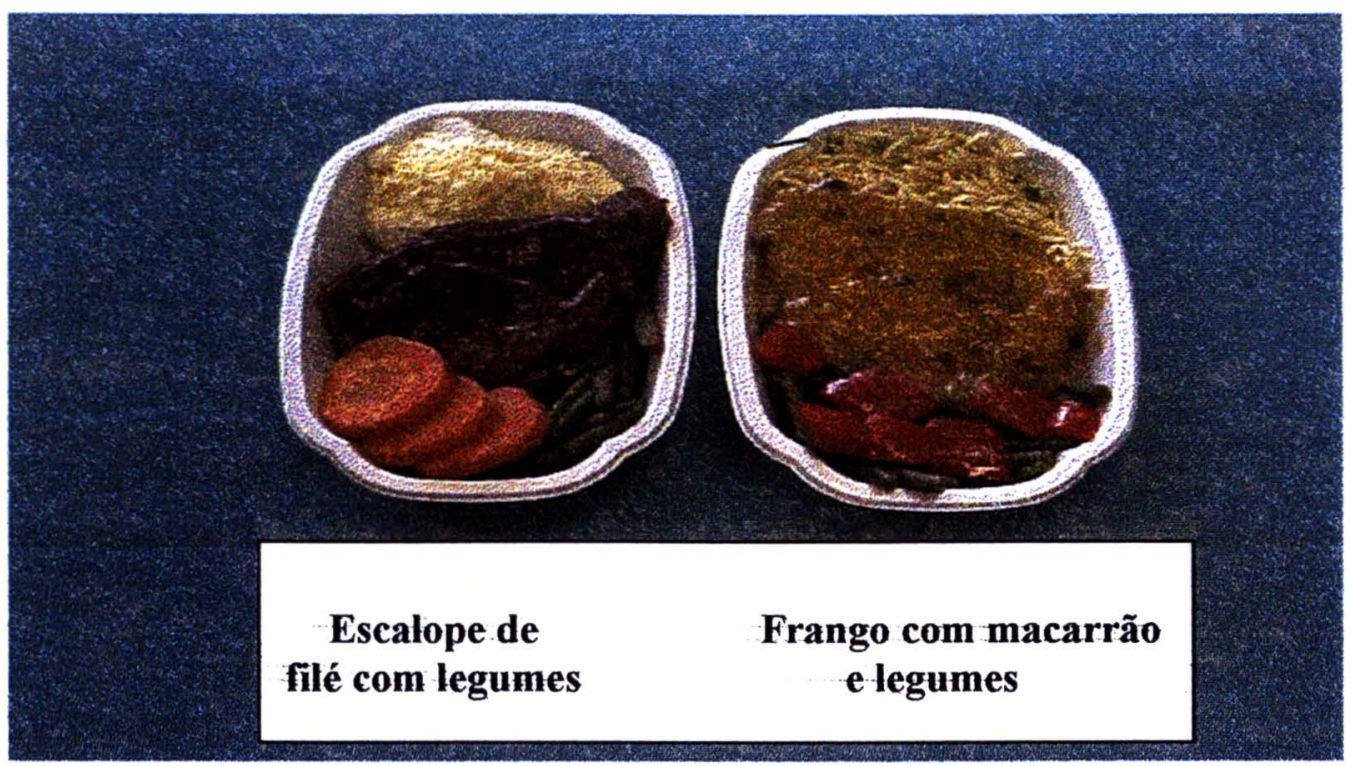

Figura 5.1c : Preparações culinárias à base de carne bovina e suas opções

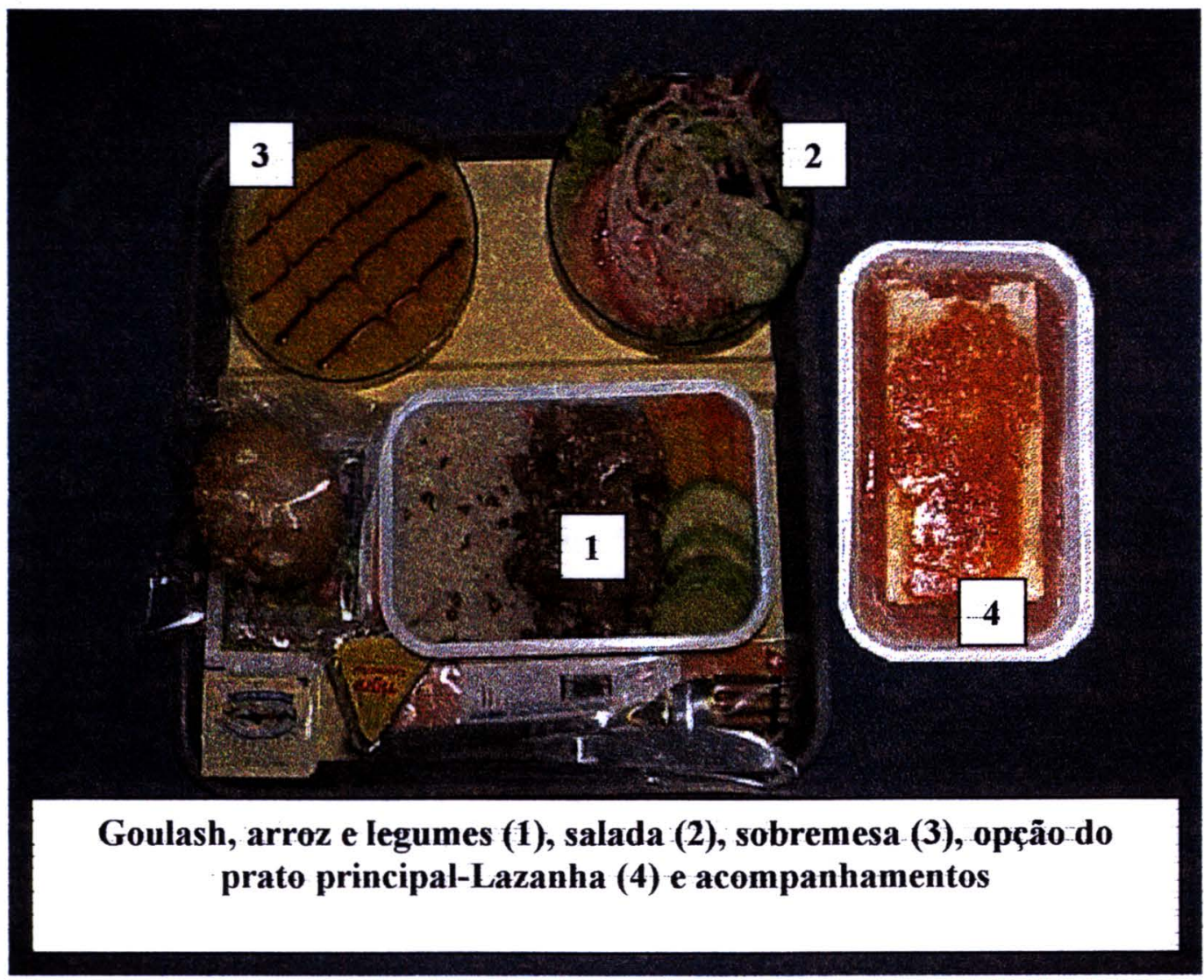

Figura 5.2 - Bandeja-pronta para o consumo a bordo 
Os diferentes tipos de preparações foram classificados em bem passadas, mal passadas e muito mal passadas, em função das características apresentadas quanto ao ponto de cocção.

O Gráfico 5.2 apresenta a distribuição das amostras quanto às características da preparação.

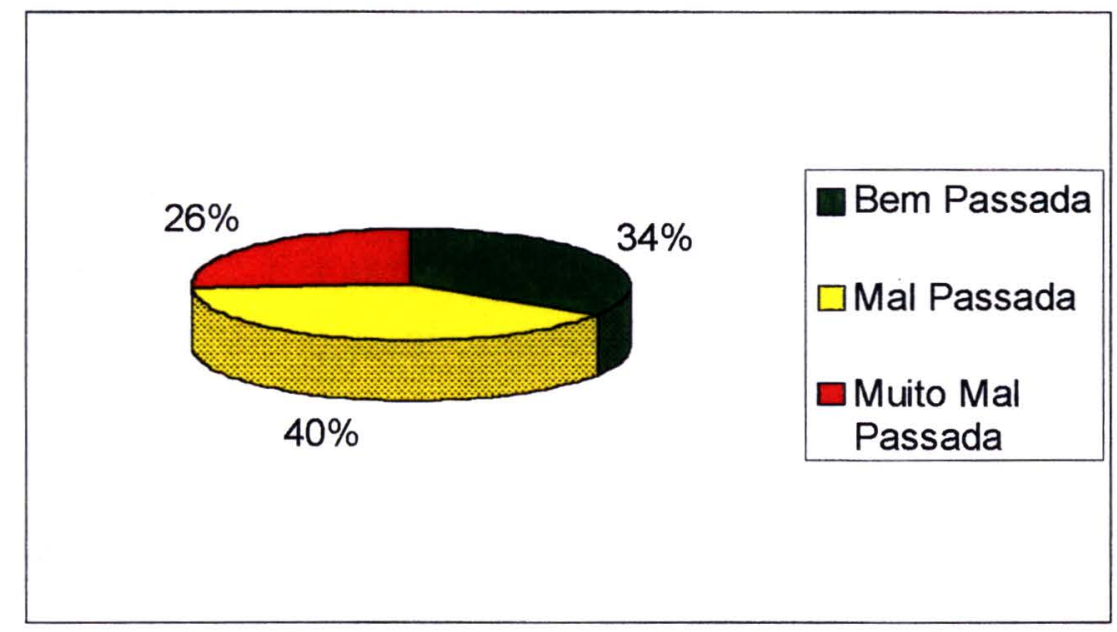

Gráfico 5.2-Distribuição das amostras quanto às características da preparação

\section{2 -Análises microbiológicas}

As análises microbiológicas das 50 amostras foram realizadas para a contagem de coliformes totais e Escherichia coli e para a deteç̧ão de Salmonella spp, Listeria spp, Staphylococcus aureus e E. coli O 157 :H7. Os valores referentes à contagem de coliformes totais e $E$. coli são apresentados na Tabela 5.1. 
Tabela 5.1- Resultados da contagem de coliformes totais e $\boldsymbol{E}$. coli em 50 amostras de preparações com carne bovina

\begin{tabular}{cccccc}
\hline Amostra & $\begin{array}{c}\text { Coliformes } \\
\text { totais (UFC/g) }\end{array}$ & $\begin{array}{c}\text { E.coli } \\
(\mathrm{UFC} / \mathrm{g})\end{array}$ & Amostra & $\begin{array}{c}\text { Coliformes } \\
\text { totais (UFC/g) }\end{array}$ & $\begin{array}{c}\text { E.coli } \\
\text { (UFC/g) }\end{array}$ \\
\hline 1 & $3,0 \times 10$ & $<10$ & 26 & $1,0 \times 10$ & $<10$ \\
2 & $<10$ & $<10$ & 27 & $<10$ & $<10$ \\
3 & $3,9 \times 10^{2}$ & $<10$ & 28 & $1,9 \times 10^{2}$ & $<10$ \\
4 & $1,0 \times 10$ & $<10$ & 29 & $2,2 \times 10^{2}$ & $<10$ \\
5 & $3,0 \times 10$ & $<10$ & 30 & $4,3 \times 10^{2}$ & $<10$ \\
6 & $1,9 \times 10^{2}$ & $<10$ & 31 & $<10$ & $<10$ \\
7 & $7,0 \times 10$ & $1,0 \times 10$ & 32 & $3,0 \times 10$ & $<10$ \\
8 & $1,6 \times 10^{2}$ & $<10$ & 33 & $4,8 \times 10^{2}$ & $<10$ \\
9 & $2,4 \times 10^{2}$ & $<10$ & 34 & $3,0 \times 10$ & $1,0 \times 10$ \\
10 & $<10$ & $<10$ & 35 & $3,0 \times 10$ & $<10$ \\
11 & $4,9 \times 10^{2}$ & $<10$ & 36 & $1,4 \times 10^{3}$ & $4,2 \times 10^{2}$ \\
12 & $<10$ & $<10$ & 37 & $1,0 \times 10$ & $<10$ \\
13 & $9,8 \times 10^{2}$ & $<10$ & 38 & $1,0 \times 10^{2}$ & $<10$ \\
14 & $2,4 \times 10^{2}$ & $<10$ & 39 & $<10$ & $<10$ \\
15 & $<10$ & $<10$ & 40 & $7,0 \times 10$ & $<10$ \\
16 & $<10$ & $<10$ & 41 & $<10$ & $<10$ \\
17 & $1,4 \times 10^{3}$ & $<10$ & 42 & $<10$ & $<10$ \\
18 & $<10$ & $<10$ & 43 & $<10$ & $<10$ \\
19 & $2,4 \times 10^{2}$ & $<10$ & 44 & $1,2 \times 10^{2}$ & $<10$ \\
20 & $5,0 \times 10$ & $<10$ & 45 & $2,9 \times 10^{2}$ & $<10$ \\
21 & $<10$ & $<10$ & 46 & $<10$ & $<10$ \\
22 & $1,4 \times 10^{3}$ & $<10$ & 47 & $1,0 \times 10$ & $<10$ \\
23 & $<10$ & $<10$ & 48 & $3,1 \times 10^{2}$ & $<10$ \\
24 & $1,0 \times 10$ & $<10$ & 49 & $5,2 \times 10^{2}$ & $<10$ \\
25 & $2,0 \times 10$ & $<10$ & 50 & $1,0 \times 10$ & $<10$ \\
\hline & & & & & \\
\hline
\end{tabular}


Dentre as cinqüenta amostras, trinta e cinco (70\%) revelaram a presença de coliformes totais, sendo que os valores variaram de 10 a $1,4 \times 10^{3} \mathrm{UFC} / \mathrm{g}$.

A presença de $E$. coli foi detectada em 3 amostras (6\%), sendo que uma delas (amostra 36) apresentou 4,2 × $10^{2} \mathrm{UFC} / \mathrm{g}$, encontrando-se portanto em desacordo com o padrão microbiológico utilizado ( $R D C n^{\circ} 12$ / 2001). Esta amostra apresentou também uma maior contagem de coliformes totais.

\subsection{1 - Relação entre coliformes totais, tipo de preparação, características da preparação e tempo de embalagem}

A distribuição da contagem de coliformes totais em relação ao tipo de preparação encontra-se apresentada na Tabela 5.2.

Tabela 5.2 -Distribuição das amostras segundo a contagem de coliformes totais e tipo de preparação

\begin{tabular}{cccccc}
\hline & \multicolumn{4}{c}{ Coliformes totais (UFC/g) } & \multirow{2}{*}{ Total } \\
\cline { 2 - 5 } Tipo de prearação & $<10$ & $10-100$ & $101-1000$ & $>1001$ & 2 \\
\hline Brochete de filé & 0 & 1 & 1 & 0 & 14 \\
Escalope de filé & 3 & 7 & 4 & 0 & 2 \\
Filé á parmeggiana & 0 & 0 & 1 & 1 & 5 \\
Goulash & 3 & 1 & 1 & 0 & 3 \\
Lagarto assado fatiado & 0 & 1 & 1 & 1 & 4 \\
Rosbife & 0 & 2 & 2 & 0 & 20 \\
Tornedor de filé & 9 & 4 & 6 & 1 & 50 \\
\hline Total & 15 & 16 & 16 & 3 & \\
\hline
\end{tabular}


A comparação das contagens de coliformes totais, considerando o tipo de preparação, realizada através da extensão do teste exato de Fisher não detectou diferença na proporção destas variáveis $(p=0,251)$

A Tabela 5.3 apresenta a distribuição das contagens de coliformes totais segundo características da preparação.

Tabela 5.3 - Distribuição das amostras segundo contagem de coliformes totais e características da preparação

\begin{tabular}{|c|c|c|c|c|c|}
\hline \multirow[b]{2}{*}{ Características da preparação } & \multicolumn{4}{|c|}{ Coliformes totais (UFC/g) } & \multirow[b]{2}{*}{ Total } \\
\hline & $<10$ & $10-100$ & $101-1000$ & $>1001$ & \\
\hline Bem passada & 4 & 6 & 5 & 2 & 17 \\
\hline Mal passada & 8 & 8 & 4 & 0 & 20 \\
\hline Muito mal passada & 3 & 2 & 7 & 1 & 13 \\
\hline Total & 15 & 16 & 16 & 3 & 50 \\
\hline
\end{tabular}

A comparação das contagens de coliformes totais segundo as características da preparação foi feita por meio de da análise da variância .

A partir desta análise verificou-se que, as contagens de coliformes totais foram estatisticamente iguais nas três características de preparação $(p=0,071)$.

A distribuição da contagem de coliformes totais em relação ao tempo de embalagem apresenta-se na Tabela 5.4. 
Tabela 5.4 -Distribuição das amostras segundo a contagem de coliformes totais e tempo de embalagem

\begin{tabular}{|c|c|c|c|c|c|}
\hline \multirow[b]{2}{*}{ Tempo de embalagem } & \multicolumn{4}{|c|}{ Coliformes totais (UFC/g) } & \multirow[b]{2}{*}{ Total } \\
\hline & $<10$ & $10-100$ & $101-1000$ & $>1001$ & \\
\hline 24 horas & 2 & 6 & 7 & 1 & 16 \\
\hline No dia da análise & 13 & 10 & 9 & 2 & 34 \\
\hline Total & 15 & 16 & 16 & 3 & 50 \\
\hline
\end{tabular}

A comparação da contagem de coliformes totais, segundo o tempo de embalagem, também realizada através da análise de variância, mostrou que ambos apresentaram contagens médias de coliformes totais estatisticamente iguais $(p=0,662)$.

\subsection{2 - Relação entre $E$. coli, tipo de preparação, características da preparação e tempo de embalagem}

A Tabela 5.5 apresenta a distribuição da contagem de $E$. coli segundo o tipo de preparação.

Tabela 5.5 - Distribuição das amostras segundo a contagem de $E$. coli e tipo de preparação

\begin{tabular}{ccccc}
\hline & \multicolumn{3}{c}{ E.coli (UFC)/g } & \\
\cline { 2 - 4 } Tipo de preparação & $<10$ & $10-100$ & $101-1000$ & Total \\
\hline Brochete de filé & 2 & 0 & 0 & 2 \\
Escalope de filé & 12 & 2 & 0 & 14 \\
Filé á parmeggiana & 1 & 0 & 1 & 2 \\
Goulash & 5 & 0 & 0 & 5 \\
Lagarto assado fatiado & 3 & 0 & 0 & 3 \\
Rosbife & 4 & 0 & 0 & 4 \\
Tornedor de filé & 20 & 0 & 0 & 20 \\
\hline Total & 47 & 2 & 1 & 50 \\
\hline
\end{tabular}


A comparação entre as contagens de $E$. coli, considerando o tipo de preparação, realizada por meio do teste $\chi^{2}$, não revelou diferença nas proporções destas variáveis $(p=0,131)$.

A distribuição da contagem de $E$. coli segundo características da preparação está apresentada na Tabela 5.6.

Tabela 5.6 - Distribuição das amostras segundo a contagem de E.coli por características da preparação

\begin{tabular}{ccccc}
\hline & \multicolumn{4}{c}{ E. coli (UFC/g) } \\
\cline { 2 - 4 } Característica da preparação & $<10$ & $10-100$ & $101-1000$ & Total \\
\hline Bem passada & 15 & 1 & 1 & 17 \\
Mal passada & 19 & 1 & 0 & 20 \\
Muito mal passada & 13 & 0 & 0 & 13 \\
\hline Total & 47 & 2 & 1 & 50 \\
\hline
\end{tabular}

Comparando-se as contagens de $E$. coli, em função das características da preparação por meio do teste $\chi^{2}$, verificou-se não existir diferença entre as características $(p=0,890)$.

A Tabela 5.7 apresenta a distribuição das contagens de $E$. coli segundo tempo de embalagem.

Tabela 5.7 - Distribuição das amostras segundo a contagem de $\boldsymbol{E}$. coli e tempo de embalagem

\begin{tabular}{ccccc}
\hline & \multicolumn{5}{c}{$E$. coli (UFC/g) } \\
\cline { 2 - 5 } Tempo de embalagem & $<10$ & $10-100$ & $101-1000$ & Total \\
\hline 24 horas & 14 & 1 & 1 & 16 \\
No dia da análise & 33 & 1 & 0 & 34 \\
\hline Total & 47 & 2 & 1 & 50 \\
\hline
\end{tabular}


A comparação das contagens de $E$. coli, em função do tempo de embalagem, pela aplicação do teste $\chi^{2}$ mostrou não existir diferença estatística na proporção das variáveis estudadas $(\mathrm{p}=0,237)$.

5.2.3 - Relação entre coliformes totais, $E$. coli e temperatura das amostras no momento da coleta

A temperatura das amostras encontra-se representada no Quadro 5.1 (ANEXO).

O estudo da relação linear, entre a temperatura, contagem de coliformes totais e E. coli foi feito por meio do cálculo do coeficiente de correlação linear de Pearson.

Verificou-se através dos resultados que não existe relação linear entre estas variáveis conforme apresentado na Tabela 5.8 .

Tabela 5.8 - Estimativa do coeficiente de correlação linear de Pearson

\begin{tabular}{lcc}
\hline \multicolumn{1}{c}{ Variáveis } & Coeficiente de correlação & Nivel descritivo $(p)$ \\
\hline Temperatura e Coliformes & 0,122 & 0,397 \\
Temperatura e $E$. coli & $-0,158$ & 0,272 \\
\hline
\end{tabular}

\subsection{4- Relação entre Salmonella spp, tipo de preparação, características da} preparação, tempo de embalagem e temperatura

A distribuição das amostras, segundo detecção de Salmonella spp e tipo de preparação, encontra-se apresentada na Tabela 5.9 
Tabela 5.9 - Distribuição das amostras segundo presença de Salmonella spp por tipo de preparação

\begin{tabular}{cccc}
\hline & \multicolumn{2}{c}{ Salmonella spp } & \\
\cline { 2 - 3 } Tipo de Preparação & Ausência & Presença & Total \\
\hline Brochete de filé & 1 & 1 & 2 \\
Escalope de filé & 8 & 6 & 14 \\
Filé á parmeggiana & 1 & 1 & 2 \\
Goulash & 3 & 2 & 5 \\
Lagarto assado fatiado & 3 & 0 & 3 \\
Rosbife & 3 & 1 & 4 \\
Tornedor de filé & 15 & 5 & 20 \\
\hline Total & 34 & 16 & 50 \\
\hline
\end{tabular}

O estudo da presença de Salmonella spp, segundo tipo de preparação, realizado por meio do teste $\chi^{2}$, mostrou não existir diferença entre as preparações $(p=0,750)$.

A pesquisa da presença de Salmonella spp revelou que, do total das 50 amostras analisadas, 16 apresentaram resultado positivo. Os resultados obtidos mostram que $32 \%$ das amostras analisadas encontraram-se fora do padrão microbiológico recomendado pela RDC $n^{\circ} 12 / 2001$.

A Tabela 5.10 apresenta a distribuição das amostras segundo deteç̧ão de Salmonella spp e características da preparação. 
Tabela 5.10 - Distribuição das amostras segundo presença de Salmonella spp e características da preparação

\begin{tabular}{cccc}
\hline & \multicolumn{2}{c}{ Salmonella spp } & \multirow{2}{*}{ Características da Preparação } \\
\cline { 2 - 3 } & Ausência & Presença & Total \\
\hline Bem passada & 11 & 6 & 17 \\
Mal passada & 15 & 5 & 20 \\
Muito mal passada & 8 & 5 & 13 \\
\hline Total & 34 & 16 & 50 \\
\hline
\end{tabular}

A verificação da comparação, entre as variáveis estudadas, através do teste $\chi^{2}$ mostrou que não há diferença significante na proporção entre Salmonella spp e características da preparação $(p=0,676)$.

A distribuição da deteç̧ão das amostras para Salmonella spp e tempo de embalagem consta na Tabela 5.11.

Tabela 5.11 - Distribuição das amostras segundo presença de Salmonella spp e tempo de embalagem

\begin{tabular}{cccc}
\hline & \multicolumn{2}{c}{ Salmonella spp } & \\
\cline { 2 - 3 } Tempo de embalagem & Ausência & Presença & Total \\
24 horas & 11 & 5 & 16 \\
No dia da análise & 23 & 11 & 34 \\
\hline Total & 34 & 16 & 50 \\
\hline
\end{tabular}

A relação entre, Salmonella spp e tempo de embalagem, foi estudada através da.aplicação do teste $\chi^{2}$, verificando-se que não há diferença estatística na proporção destas variáveis $(p=0,938)$.

A Tabela 5.12 apresenta a distribuição das amostras segundo a pesquisa de Salmonella spp e a temperatura das preparações. 
Tabela 5.12 - Medidas - resumo da temperatura segundo resultado para Salmonella spp

\begin{tabular}{cccc}
\hline & & \multicolumn{2}{c}{ Temperatura $\left({ }^{\circ} \mathrm{C}\right)$} \\
\cline { 3 - 4 } Resultado para Salmonella spp & $\mathrm{N}$ & Média & Desvio-padrão \\
\hline Ausência & 34 & 10,99 & 2,97 \\
Presença & 16 & 11,56 & 3,85 \\
\hline
\end{tabular}

A comparação da temperatura das preparações, segundo os resultados da pesquisa de Salmonella spp, foi realizada através do teste t de Student para amostras não relacionadas. Verificou-se que as amostras com presença de Salmonella spp apresentaram temperaturas médias estatisticamente iguais quando comparadas às amostras com ausência de Salmonella $\operatorname{spp}(\mathrm{p}=0,601)$.

\subsection{5 - Relação entre Listeria spp, tipo de preparação, características da} preparação, tempo de embalagem e temperatura

A distribuição das amostras, segundo presença de Listeria spp e tipo de preparação apresenta-se na Tabela 5.13.

Tabela 5. 13 - Distribuição das amostras segundo a presença de Listeria spp e 0 tipo de preparação

\begin{tabular}{cccc}
\hline & \multicolumn{2}{c}{ Listeria spp } & \\
\cline { 2 - 3 } Tipo de Preparação & Ausência & Presença & Total \\
\hline Brochete de filé & 2 & 0 & 2 \\
Escalope de filé & 12 & 1 & 13 \\
Filé à parmeggiana & 1 & 1 & 2 \\
Goulash & 6 & 1 & 7 \\
Lagarto assado fatiado & 3 & 0 & 3 \\
Rosbife & 4 & 0 & 4 \\
Tornedor de filé & 19 & 0 & 19 \\
\hline Total & 47 & 3 & 50 \\
\hline
\end{tabular}


O estudo da presença de Listeria spp segundo tipo de preparação, realizado através do teste $\chi^{2}$ mostrou não haver diferença na proporção dessas variáveis $(p=0,097)$.

A pesquisa de Listeria spp demonstrou que $6 \%$ das amostras estavam contaminadas por este microrganismo, como demonstra a Tabela 5.13.

A Tabela 5.14 apresenta a distribuição das amostras segundo Listeria spp e características da preparação.

Tabela 5.14 : Distribuição das amostras segundo presença de Listeria spp e características da preparação

\begin{tabular}{cccc}
\hline & \multicolumn{2}{c}{ Listeria spp } & \multirow{2}{*}{ Caracteristicas da Preparação } \\
\cline { 2 - 3 } & Ausência & Presença & Total \\
\hline Bem passada & 16 & 1 & 17 \\
Mal passada & 19 & 1 & 20 \\
Muito mal passada & 12 & 1 & 13 \\
\hline Total & 47 & 3 & 50 \\
\hline
\end{tabular}

A comparação das proporções das variáveis estudadas através do teste $\chi^{2}$ mostrou que não há relação significante entre presença de Listeria spp e características da preparação $(\mathrm{p}=0,950)$.

A distribuição das amostras segundo presença de Listeria spp e tempo de embalagem consta na Tabela 5.15. 
Tabela 5.15 - Distribuição das amostras segundo presença de Listeria spp e tempo de embalagem

\begin{tabular}{cccc}
\hline & \multicolumn{2}{c}{ Listeria spp } & \\
\cline { 2 - 3 } Tempo de embalagem & Ausência & Presença & Total \\
\hline 24 horas & 15 & 1 & 16 \\
No dia da análise & 32 & 2 & 34 \\
\hline Total & 47 & 3 & 50 \\
\hline
\end{tabular}

A relação entre Listeria spp e tempo de embalagem foi estudada através da aplicação do teste $\chi^{2}$,não detectando-se diferença na proporção dessas variáveis $(p=0,959)$

A Tabela 5.16 apresenta os valores médios de temperatura segundo a presença de Listeria spp .

Tabela 5.16 - Medidas - resumo da temperatura segundo resultado para Listeria spp

\begin{tabular}{cccc}
\hline & \multicolumn{3}{c}{ Temperatura $\left({ }^{\circ} \mathrm{C}\right)$} \\
\cline { 2 - 4 } Resultado para Listeria spp & $\mathbf{n}$ & Média & Desvio-padrão \\
\hline Ausência & 47 & 11,18 & 3,22 \\
Presença & 3 & 11,00 & 4,36 \\
\hline
\end{tabular}

Para a comparação da temperatura com o resultado da pesquisa para Listeria spp, utilizou-se o teste t de Student para amostras não relacionadas, verificando-se a inexistência de diferença estatística entre os valores médios $(p=0,927)$.

A presença de Listeria spp foi identificada em três amostras (4,12 e 32): nas amostras 4 e 12, Listeria inoccua e na amostra 32, Listeria monocytogenes. 


\subsection{6 - Presença de Staphylococcus aureus}

Não foi identificada a presença de $S$. aureus nas amostras analisadas.

\subsection{7 - Presença de E. coli O 157:H7}

Não foi identificada a presença de $E$. coli O157:H7 nas amostras analisadas. 


\section{6 - DISCUSSÃO}

Um dos grandes problemas relacionados à qualidade dos alimentos consumidos pela população é o higiênico-sanitário. A presença de bactérias indicadoras de más condições de higiene, bem como de bactérias patogênicas, é uma evidência que a qualidade microbiológica é insatisfatória e, representa hoje, um grande fator de perigo à saúde do consumidor.

Numa pesquisa realizada com refeições destinadas ao consumo a bordo de aeronaves, onde foram analisadas as etapas de processamento de carne bovina, desde o recebimento até a sua distribuição na aeronave, foi observado que as relações entre tempo e temperatura poderiam comprometer a segurança do alimento e, consequentemente, a saúde do consumidor. Na etapa de cocção, a temperatura ficou abaixo dos valores estabelecidos em $86 \%$ das preparações e na etapa de armazenamento das preparações prontas observou-se que as mesmas não se apresentavam dentro dos critérios de validade estipulado pela empresa (ZANARDI 1998).

Avaliando-se as condições higiênico-sanitárias das preparações à base de carne bovina no presente estudo, verificou-se que, de acordo com as caracteristicas destas preparações, bem passada (34\%), mal passada (40\%) e muito mal passada (26\%), os critérios para cocção assemelham-se aos do estudo anterior.

O preparo das refeições de bordo requer várias etapas, incluindo em cada uma delas a manipulação. $\mathbf{O}$ intervalo de tempo entre a produção e o consumo a bordo da aeronave requer a produção de refeições resfriadas, exigindo um controle efetivo na manipulação (HATAKA et al. 2000). 
As preparações analisadas no presente estudo passaram por 10 etapas durante o processamento, sendo elas: recebimento da matéria-prima, armazenamento, prépreparo, armazenamento, preparo, resfriamento, armazenamento das preparações, montagem dos pratos, armazenamento dos pratos e transporte até a aeronave. Esse grande número de etapas aumenta a probabilidade de contaminação e/ou multiplicação de microrganismos devido à manipulação excessiva e às oscilações de temperatura.

A pesquisa de coliformes reflete as condições gerais de higiene durante a produção das refeições. No presente estudo foi identificada uma contagem elevada de coliformes totais em um grande número de amostras (70\%), o que pode constituir uma evidência de contaminação após o processamento, considerando-se que a etapa de cocção quando bem conduzida, elimina esses microrganismos.

Segundo a NBR 10269 (ABNT 2001), a cocção é a etapa onde a temperatura do alimento deve atingir no mínimo $74^{\circ} \mathrm{C}$ no seu centro geométrico, ou combinações de tempo e temperatura como $70^{\circ} \mathrm{C}$ por dois minutos ou $65^{\circ} \mathrm{C}$ por quinze minutos.

Quanto à pesquisa de $E$. coli, neste estudo, a sua presença foi detectada em três amostras, o que pode indicar falhas na manipulação após o processamento dos alimentos, uma vez que a mesma pode ser destruida na etapa de coç̧ão.

O padrão sanitário utilizado nesta pesquisa (RDC n $\left.^{\circ} 12 / A N V I S A\right)$, para a contagem de coliformes fecais, estabelece o limite de $20 \mathrm{UFC} / \mathrm{g}$, em produtos prontos para consumo. De acordo com a referida legislação, os valores encontrados nesta pesquisa demonstram-se inadequados em uma amostra (2\%), devido à presença de E.coli. Porém, segundo ALMEIDA e colaboradores (1996), a presença de 
coliformes fecais em uma concentração de três ou mais coliformes/g de alimento já é considerada insatisfatória. Considerando-se estes parâmetros, très amostras (6\%) encontram-se em condições insatisfatórias, representando um risco de contaminação por outras bactérias patogênicas.

Em um trabalho realizado por HATAKA (1998) foram analisadas 675 preparações frias servidas a bordo de aeronaves, das quais $18 \%$ dos aperitivos, $16 \%$ das saladas e $6 \%$ das sobremesas, excederam os padrões microbiológicos para $E$. coli aceitos pela Associação de Linhas Aéreas Européias (AEA).

MATNER et al. (1990) compararam o método Petrifilm E.coli com o método tradicional NMP- AOAC para determinar a eficácia do método Petrifilm na detecção de E.coli em queijos, legumes e aves, concluindo que o método Petrifilm é tão bom ou melhor que o método tradicional.

CHUNG et al.(2000) analisaram alimentos através de métodos rápidos, utilizando Petrifilm 3M, para contagem rápida de coliformes, e concluiram que os métodos rápidos podem contribuir para uma ação corretiva no preparo dos alimentos.

Salmonella spp foi detectada no presente estudo em $32 \%$ das amostras. A coç̧ão inadequada pode ter contribuído para estes resultados, pois $66 \%$ das amostras pertenciam às categorias mal passadas ou muito mal passadas.

HATAKA (1998) analisou 1012 amostras de pratos quentes servidos a bordo de aeronaves, preparados em 33 países no período de 1991 a 1994, detectando bactérias do gênero Salmonella em $0,3 \%$ das amostras.

A etapa de reaquecimento das preparações a bordo das aeronaves deveria ser controlada para que as relações tempo/temperatura sejam respeitadas, contribuindo 
assim para a redução da ocorrência de surtos causados por esta bactéria. No Brasil não há relato de surtos envolvendo refeições a bordo de aeronaves; porém, os resultados encontrados nesta pesquisa demonstram que existe a possibilidade da ocorrência de casos envolvendo essa bactéria, devido aos altos índices de Salmonella spp observados no alimento pronto para consumo a bordo.

Embora as preparações sejam reaquecidas a bordo existe um perigo de doença de origem alimentar se este reaquecimento não for efetuado a $175^{\circ} \mathrm{C}$ durante 20 minutos. O mal funcionamento do forno pode ter sido responsável por um surto de S. infantis envolvendo passageiros (HATAKA 1998).

JAKABI et al. (1999) investigaram surtos envolvendo Salmonella spp ocorridos no período de 1994 a 1997, na cidade de São Paulo, e constataram a presença de $S$. enteritidis em carne assada, espeto de almondegas, ovos, mousse de chocolate, mousse de limão, bolos, maionese de frango e arroz cozido.

$\mathrm{Na}$ investigação de surtos de doenças transmitidas por alimentos, no período de 1990 a 1999, ALMEIDA et al. (2000) identificaram a presença de Salmonella como sendo predominante em carnes e derivados $(59,7 \%)$.

Num estudo realizado com 6 mil amostras, em 40 locais que preparam alimentos para consumo a bordo de aeronaves no mundo, observou-se o isolamento de Salmonella spp em $1 \%$ das amostras. Os isolamentos mais frequentes foram feitos a partir de alimentos preparados na Índia e Indonésia (HATAKA e ASPLUND 1993).

Em 1976, o maior surto relatado de Salmonella, associado às refeições de bordo, contaminou 550 dos 2500 passageiros, e seis passageiros morreram A 
pesquisa revelou que a infecção foi causada por $S$. thyphimurium, tendo como veículo da infecção, uma salada de ovos preparada na Espanha (HATAKA e ASPLUND 1993).

A presença de Salmonella spp em preparações servidas a bordo de aeronaves, representa um risco para a saúde dos passageiros e da tripulação. Os requisitos de higiene devem ser rigorosos durante a preparação, durante o transporte e no momento de servir as refeições. Importantes fatores para a prevenção de infecções por Salmonela spp devem ser adotados, como o resfriamento logo após o preparo, manutenção da temperatura no armazenamento e no transporte, bem como o reaquecimento adequado a bordo da aeronave (LAMBIRI 1983).

O resfriamento rápido dos alimentos realizado no "blast chiller", reduz a temperatura do alimento cozido, de $70^{\circ} \mathrm{C}$ a $3^{\circ} \mathrm{C}$ (no centro do alimento) em um tempo máximo de 90 minutos. As preparações após saírem do "blast chiller", são armazenadas em câmaras frigorificas, recebendo nesta etapa etiquetas coloridas referentes aos dias da semana para identificação (ZANARDI 1998).

Segundo a NBR 10269 (ABNT 2001), a refrigeração é a etapa na qual os alimentos ou preparações são mantidos em temperatura não superior a $5^{\circ} \mathrm{C}$. $\mathrm{Na}$ etapa de reaquecimento a bordo, os alimentos que já sofreram cocção inicial, devem atingir novamente a temperatura de segurança no centro geométrico.

Num trabalho realizado por PANISELLO et al. (2000), onde foram investigadas as possiveis causas de surtos de doenças transmitidas por alimentos, na Inglaterra e País de Gales no período de 1992 a 1996, foi constatado que Salmonella spp e os alimentos de origem animal, principalmente carnes, foram os mais 
associados aos surtos ocorridos naquele período. As principais causas foram atribuídas aos seguintes fatores: aquecimento e reaquecimento inadequados, armazenamento em temperaturas impróprias, preparo muito antecipado e descongelamento inadequado. Foi também associado aos surtos, a manipulação incorreta dos alimentos, como a higienização inadequada das mãos dos manipuladores, a manipulação dos alimentos diretamente com as mãos e a contaminação cruzada, isto é, contato das preparações cozidas com alimentos crus. O ambiente inadequado também contribuiu para a ocorrência dos surtos, incluindose a higiene insuficiente de equipamentos, de utensílios e de superficies. A matéria prima inicialmente contaminada foi também associada aos surtos ocorridos.

No período de 1986 a 1998, surtos de Salmonella spp foram relatados totalizando 2961 casos no País de Gales, sendo que 68 surtos foram causados por Salmonella enteritidis (PALMER et al. 2000).

Poucos dos surtos relacionados a alimentos servidos a bordo de aeronaves são publicados e investigados adequadamente. Relatórios documentados sobre epidemias em vôos envolvem uma larga diversidade de microrganismos incluindo Escherichia coli, Clostridium perfringens, Salmonela spp, Staphylococcus aureus, Shigella spp, Campylobacter, Vibrio, virus e protozoários (LAMBIRI et al. 1995).

Em um estudo comparativo entre os métodos Reavel Salmonella (RSS) e o método tradicional, descrito pelo Manual de Análises Bacteriológicas (APHA 1992), 60 amostras foram analisadas, sendo que, 48 foram artificialmente inoculadas com Salmonella spp e 12 amostras foram mantidas como controle. Ambos os métodos detectaram a presença do microrganismo nas 48 amostras inoculadas e um resultado 
negativo para as 12 amostras do grupo controle, demonstrando portanto, completa concordância entre os métodos (BIRD et al. 1999).

Dentre os patógenos pesquisados no presente estudo, Listeria spp foi identificada em 3 amostras (6\%). A presença deste microrganismo, cuja importante característica é a capacidade de desenvolvimento em temperaturas de refrigeração, pode ser uma indicação de não inativação na etapa de cocção, de recontaminação após processamento térmico, de armazenamento em temperatura superior a $5^{\circ} \mathrm{C}$ ou ainda por armazenamento prolongado devido à não observância do prazo de validade.

A resolução $\mathrm{RDC} \mathrm{n}^{\circ}$ 12/ANVISA, utilizada como parâmetro microbiológico neste estudo, não contempla a verificação da presença de Listeria monocytogenes em produtos cárneos prontos para consumo.

Devido à severidade das infecções por Listeria monocytogenes, onde a taxa de mortalidade pode alcançar cerca de $50 \%$ e ainda não ser reconhecida sua dose minima infectiva, o FDA (Food and Drug Administration) dos Estados Unidos estabeleceu a norma de "tolerância zero" para o microrganismo em alimentos prontos para consumo (ALMEIDA et al. 1999).

Assim, a presença de Listeria monocytogenes nas refeições de bordo representa um perigo à população.

Em um trabalho realizado por SORIANO et al. (2001), foram estudadas 103 amostras compostas de vários tipos de alimentos, dentre eles, a carne bovina. $\mathbf{O}$ estudo demonstrou a ausência de Listeria spp nas amostras contendo carne bovina, 
enfatizando a importância de um controle rigoroso durante as práticas de manipulação a fim de evitar a contaminação do produto.

Em um trabalho realizado por HEREDIA et al. (2001), foram analisadas 88 amostras contendo carne bovina moída, comercializadas no varejo, no México. Os resultados demonstraram uma elevada contaminação, 11,4\% das amostras continham Salmonella spp e $62 \%$ Listeria spp, e destas $16 \%$ apresentavam-se contaminadas por Listeria monocytogenes. Em $76 \%$ das amostras, foi detectada a presença de $E$. coli, não tendo sido verificado o sorotipo E.coli O157:H7. Os autores concluíram que, embora vários microrganismos estivessem presentes em níveis relativamente altos nas amostras, a cocção destes alimentos poderia diminuir o perigo. Porém, deve-se destacar a importância da manipulação correta durante o preparo dos alimentos.

LEVINE et al. (2001) estudaram a ocorrência de Salmonela spp e Listeria monocytogenes em carnes e aves, em produtos prontos para consumo, no período de 1990 a 1999 e revelaram que a baixa ocorrência de Salmonella encontrada nestes produtos indica que a temperatura de cocção utilizada foi efetiva para eliminar este patógeno. Para Listeria monocytogenes, a ocorrência foi mais elevada, principalmente para aves, sugerindo que a indústria deva realizar um melhor controle na sua produção.

Um dos fatores que contribui com maior freqüência para a ocorrência de surtos de toxinfecções alimentares é a operação de resfriamento feita de maneira inadequada. A maioria dos problemas ocorre em função da manutenção do alimento cozido em temperatura ambiente por várias horas antes de ser refrigerado (BRYAN 1996). 
WISA et al. (2000) analisaram dois tipos de cocção de hambúrgueres denominados SSB (single-sided broiling) e DGB (double-sided grilling broiling), a fim de verificar a redução de microrganismos, bem como a qualidade da textura das preparações. Os autores constataram que o sistema DGB foi mais efetivo para a destruição de E. coli 0157:H7 e Listeria monocytogenes, sendo que o DGB atingiu mais rapidamente a temperatura interna mais elevada. Os autores verificaram também que as análises de textura no DGB apresentaram valores mais altos quando comparados ao sistema SSB.

No presente estudo, as amostras apresentaram resultados negativos para $S$. aureus . Estes resultados podem indicar que as boas práticas de higiene pessoal na produção dos alimentos foram aplicadas. $\mathrm{O}$ manipulador com ferimentos nas mãos, não deve tocar os alimentos prontos para consumo diretamente, como também, não deve conversar durante o preparo e, sobretudo tossir sobre os alimentos. Desta forma, um treinamento efetivo deve ser implantado para que todos os funcionários adotem a mesma conduta de higiene pessoal.

Num trabalho realizado por YASSEN $e$ al. (1990), onde foram analisadas as refeições prontas para consumo a bordo de aeronaves, foi verificada a presença de Staphylococcus aureus em 7,5\% das amostras. A partir dos dados obtidos, os autores recomendam que a higiene adequada das mãos deva ser realizada e a utilização de luvas deva ser adotada como uma conduta na manipulação de alimentos prontos. Programas educacionais devem ser propostos aos manipuladores de alimentos para melhorar a qualidade dos produtos e garantir o máximo de segurança aos passageiros. 
Deve-se ressaltar que o resultado negativo para $S$. aureus no presente estudo, não elimina o perigo da ocorrência de toxinfecção alimentar, pois, podem estar presentes as toxinas produzidas por este microrganismo, as quais são termorresistentes e podem não ter sido destruídas no processo de cocção dos alimentos.

A etapa de reaquecimento a bordo das aeronaves, quando bem controlada pode reduzir os perigos de contaminação mas, de maneira geral, não é suficiente para destruir todos os microrganismos presentes no alimento (HATAKA 1998).

Em relação à Echerichia coli 0157:H7, o presente estudo não obteve resultado positivo nas análises microbiológicas.

Até o presente momento, não há relatórios de ocorrência de surtos de origem alimentar envolvendo E. coli O 157:H7, em nosso país (SAAD e FRANCO 1999).

A ocorrência de Escherichia coli 0157:H7, manifesta-se, atualmente, nos países desenvolvidos como também em alguns países em desenvolvimento, sendo que, dentre os alimentos incriminados em surtos, a carne bovina é um dos veículos potenciais dessa bactéria. A prevenção deveria ter início na seleção da matéria prima, desde a produção no campo até o processamento e distribuição através de programas de higiene e sanificação do ambiente e dos manipuladores (NASCIMENTO e STAMFORD 2000).

UHITL et al. (2001) analisaram 114 amostras de carne bovina e suína na Croácia e os resultados apresentaram-se igualmente negativos em todas as amostras para E.coli 0157:H7. 
ATTENBOROUGH et al. (2000) verificaram que um elemento importante de defesa contra E. coli $\mathrm{O} 157: \mathrm{H} 7$, na indústria de carne vermelha, está no desenvolvimento e introdução de técnicas de avaliação de perigos baseadas no sistema HACCP (Hazard Analysis and Critical Control Point / Análise de Perigos em Pontos Crítico de Controle).

Para o controle da contaminação por $E$. coli $0157: H 7$, seria necessário o desenvolvimento de testes rápidos para a detecção deste patógeno no gado, melhoria das operações de abate e do processamento dos alimentos, objetivando a redução da contaminação, desenvolvimento de novas tecnologias para a eliminação de $E$. coli 0157:H7 e para a conservação dos alimentos, como também a orientação dos consumidores sobre métodos adequados de manipulação e preparo de alimentos (ORMENESE et al. 1999).

\section{1- Considerações finais}

Os dados obtidos no presente estudo demonstram a necessidade da correção das práticas de higiene no preparo de alimentos, reforçando a necessidade de uma melhor orientação aos manipuladores quanto ao tratamento térmico, ao armazenamento dos alimentos e ao controle efetivo do prazo de validade das preparaçōes.

O sistema HACCP, apesar de implantado na empresa estudada nesta pesquisa, requer um monitoramento efetivo e, ações corretivas devem ser tomadas principalmente na etapa de coç̧ão. 
Alimentos contaminados servidos a bordo de aeronaves, além de implicarem na segurança do vôo, devido ao consumo dos mesmos pela tripulação, podem se tornar um perigo à saúde dos passageiros, principalmente se o vôo for internacional, pois a demora no atendimento pode agravar o quadro clínico apresentado.

Para que os passageiros e a tripulação não sejam expostos ao perigo de adquirir uma doença de origem alimentar, as refeições devem ser entregues a bordo apresentando uma baixa probabilidade de risco e, para que isso ocorra, deve ser dada ênfase a um controle mais eficiente nas diferentes etapas do processo de preparação dos alimentos.

Os tipos de preparações pesquisadas neste estudo sugerem que deve haver uma modificação no cardápio elaborado para as refeições servidas a bordo de aeronaves, eliminando-se as preparações muito mal passadas a fim de não oferecer aos passageiros e à tripulação, preparações de risco. 


\section{7- CONCLUSÕES}

- A qualidade microbiológica verificada neste estudo demonstra que houve manipulação inadequada na produção das refeições para consumo a bordo de aeronaves. As contagens de coliformes totais e $E$. coli observadas podem indicar que esses microrganismos estavam presentes na matéria-prima e não foram inativados na etapa de coç̧ão ou que as preparações foram contaminadas após a cocção.

- $32 \%$ das amostras analisadas revelaram-se impróprias para consumo devido a presença de Salmonella spp. A alta incidência desse microrganismo é mais uma indicação da falta de controle na etapa de coç̧ão ou de recontaminação após essa etapa.

- $6 \%$ das amostras analisadas revelaram-se contaminadas por Listeria spp, sendo que uma delas (2\%) foi identificada como Listeria monocytogenes, representando um grande perigo à saúde dos passageiros e tripulação.

- A ausência de Staphylococcus aureus reflete que as boas práticas de higiene pessoal na manipulação dos alimentos foram aplicadas pelos manipuladores, porém não elimina a possibilidade da presença de enterotoxinas.

- Como E. coli 0157:H7 não está disseminada em nosso país, a verificação de sua ausência não é suficiente para a obtenção de conclusões quanto à qualidade da matéria prima e também quanto à eficiência do processo de cocção. 
- O controle da etapa de armazenamento das preparações prontas para consumo, quanto ao critério tempo/temperatura pode minimizar a multiplicação dos agentes já presentes no alimento.

- Não foi possivel estabelecer uma relação entre temperatura do produto final e a presença dos microrganismos estudados.

- A presença de agentes patogênicos nas refeições de bordo, representa um perigo à saúde pública, principalmente para idosos, crianças e gestantes.

- A não existência de correlação entre as características das preparações e o perfil microbiológico talvez possa ser atribuído ao número de amostras estudadas.

- A utilização de testes rápidos para a avaliação da qualidade microbiológica das refeições servidas a bordo de aeronaves pode ser um instrumento importante para a prevenção da ocorrência de surtos, impedindo que refeições contaminadas sejam servidas. 


\section{8 - REFERÊNCIAS BIBLIOGRÁFICAS ${ }^{*}$}

ABNT (Associação Brasileira de Normas Técnicas) NBR 10269. Aeroportos Controle Higiênico-Sanitário de alimentos em comissarias de bordo; 2001

Adams C. Use of HACCP in meat and poultry inspection. Food Technol 1990; 44 (5) : $169-170$.

Adams MR, Moss MO Food microbiology Cambridge: The Royal Society of Chemistry; 1997.

Alcaráz LE, Satorres SE, Sepulveda L, Centorbi ON. Detection of Staphylococcus aureus em manipuladores de alimentos. La Alimentación Latino Americana.1997; 219:44-47.

Almeida CR, Schuch DM, Gelli DS, Cuéllar JA, Diez AV, Escamilla JA. Contaminación microbiana de los alimentos vendidos en la vía pública en ciudades de América Latina y características socio-economicas de sus vendedores e consumidores. Washington, (DC); 1996(OPAS).

Almeida CR. O sistema HACCP como instrumento para garantir a inocuidade dos alimentos. Rev Hig Aliment 1998; 12 (53): 12-20.

Almeida PF, Almeida, RCC, Rodrick,GU. Listeria monocytogenes: Importância e distribuição nos alimentos. Rev Hig Aliment 1999; 13 (64): 19- 23.

Almeida IAZ, Peresi JTM, Carvalho IS, Rodrigues ECA, Marques DF, Tavechio AT e Fernandes AS. Salmonella: sorotipos identificados na região de São José do Rio Preto/SP, no período de 1990-1999. Rev Inst Adolfo Lutz 2000; 59 (1/2) : 33-37.

Altekruse SF, Cohen ML, Swerdlow DL. Emerging Foodborn Diseases. Emerging Infect Dis $1997 ; 3$ (3): 1-12.

AOAC. Association of Official Analytical Chemists. 2000. <URL_http://aoac.org/ testkits/testedmethods.html $>$ [2000 Dec 11]

APHA. American Public Health Association.2000. <URL :http://apha.org $>[2000$ Nov 10]

Araujo E. Surtos alimentares por Salmonella enteritidis associados ao consumo de alimentos à base de ovos, em Sorocaba, SP. Rev Hig Aliment 1995; 9 (40) : 24-26.

\footnotetext{
* Segundo Guia de Apresentação de teses Biblioteca/CIR - São Paulo: Faculdade de Saúde Pública USP, 1998.
} 
Archer, DP. Listeria monocytogenes: the science and police. Food Control 1996; $7: 181-182$.

Ariyapitipun T, Mustapha A, Clarke AD. Survival of Listeria monocytogenes scott on vaccum package raw beef treated with polylatic acid, lactic acid and nisin. J Food Protec 2000;63 (1) : 131-136.

Attenborough M e Matheus KR. Food safety trough the meat supply chain J Applied Microbiology Symposium Suplement 2000; 88 : 144-148.

Bailey J. Food. In: guide to Hygiene and Sanitation in Aviation. Genebra : (WHO) World Health Organization 1977; 17-63.

Bean NH, Goulding JS, Daniels MT e Angulo FJ. Surveillance for foodborne disease outbreaks - United States, 1988 - 1992. J Food Protec 1997; 60 (10) : 1265 - 1286.

Bell BP, Goldoft M, Griffin PM et al. A multistate outbreak of Escherichia coli 0157: H7-Associated bloody diarrhea and hemolytic uremic syndrome from hamburguers. J Amer Med Assoc 1994; 272 (17) : 1349-1353.

Beltran JFN, Cunhaneto A, Pires EMF, Stamford TLM. Avaliação microbiológica de refeições servidas por empresas aéreas nacionais. Rev Hig Aliment 1999; 13 (59) 49-56.

Bird CB, Miller RL, Miller BM. Reveal for Salmonella Test System. J of AOAC International $1999 ; 82(3): 625-633$.

Bittar C. Catering aéreo: $O$ prazer e a segurança das refeições nas viagens. Nutinews $2001 ; 180: 12-15$.

Bonner C, Foley B, Wall PG, Fitzgerald M. Analysis of outbreaks of infections intestinal disease in Ireland : 1988 and 1999. Irish Medical Journal 2001; 94 (5) : 140-144).

Bracket, RE. Presence and persistence of Listeria monocytogenes in food and water. Food Technol 1988; 4: $162-164$.

Brasil, Ministério da Saúde. Portaria n 1428 , de 26 de Novembro de 1993. Diário Oficial da União, Brasília, 2 de Dezembro de 1993. sec. 1/18415.

Brasil, Agência Nacional de Vigilância Sanitária. Resolução RDC no 12, de 02.01.01: Regulamento técnico sobre padrões microbiológicos para alimentos. Diário Oricial da União, Brasília 10 Jan 2001 Disponível em <URL : tttp://www.anvisa.gov.br/legis/resol/12-01 rdc.htm> [2001 Mai 10] 
Bryan FL, Seabolt KA, Peterson RW, Roberts LM. Time-temperature observations of food and equipment in airline catering operations. I Food Protec 1978; 4 (2): 80 92.

Bryan FL Hazard Analysis Critical Control Point. A guide to identifying hazards and assessing risks associated with food preparation and storage. Geneva Word Health Organization, 1992.

Bryan FL. Atualização em APPCC - Análise de Perigos em Pontos Críticos de Controle. A Qualidade dos alimentos através de uma linguagem universal. São Paulo. SESC, 1996 (Apostila do Curso).

Caffer MI, Eiger T. Salmonella enteritidis in Argentina. Int J Food Microbiol. 1994; 21 : 15- 19.

[CDHS] California Departament Of Health Sevices. Foodborne outbreaks in California. 1993-1994. Dairy, Food and Environ Sanit 1995; 15 (10): 611- 615.

[CDC] Centers For Diseases Control . Preliminary FoodNet Data on the Incidence of Foodforne Illness.Selected Sites, Estados Unidos, 1999. MMWR49 (10);201-5. <URL :http://www.cdc.gov/epo/mmwr/preview/mmwrhtml/ mm4910a1.htm> $[13 / 12 / 00]$

[CDC] Centers For Diseases Control. Preventing foodborne illness:EscherichiacoliO157:H7.1998.<URL $\quad: \quad$ URL :http://www.cdc.gov/ncidod/publications/brochures/e_coli.htm $>$ [1998 Mai 30]

[CDC] Centers For Diseases Control. Preventing foodborne illness: Salmonella.2001. <URL : http://www.cdc.gov/incidod/publications/salmonellosis $>[2002$ Fev 10]

Chung KS, Kim C N, Namgoong K. Evaluation of the Petrifilm Rapid coliform Count Plate method for Coliform Enumeration from surimi-based imitation Crab Slurry. J Food Protec 2000; 63 (1) : 123-125.

Cremer ML, Chipley JR Time and temperature, microbiological and sensory quality of meat loaf in a commissary foodservice system transporting heatedfood. J Food Sci 1979; 44 (2) : $371-326$.

[CVE] Centro de Vigilância Epidemiológica. Secretaria do Estado da Saúde de São Paulo. Vigilância epidemiológica das doenças transmitidas por alimentos. São Paulo; 1999. (CVE - Manual do Sistema de Informação). 
[CVE] Centro de Vigilância Epidemiológica. Doenças transmitidas por AlimentosVigilância de alimentes. 2000 . $<$ URL http://www.cve.saude.sp.gov.br $>[2000$ Nov 25]

Destro MT, Serrano AM, Kabuki DY. Isolation of Listeria species from some Brazilian meat and dairy produts. Food control 19912 (2) : 110-112.

Doyle MP, Beuchat LR, Montville TJ. Food Microbiology : Fundamentals and Frontiers Washington (DC), ASM Press; 1997.

Duggan J e Phillips CA. Listeria in the domestic environment. Nutrition \& Food Service 1988; $2: 73-79 ; 1998$.

Eberhart-Phillips J. Besser RE, Tormey MP, Koo D, Araneta MR, Wells J et al. An outbreak of colera from food served on na international aircraft. Epidemiol Infect $1996 ; 116(1): 9-13$.

Eisenberg MS, Gearslev K, Brown W, Horwits M, Hill D. Staphylococcal food poisoning aboard a comercial aircraft. Lancet 1975;2 (7935) : 595-599.

Einsenberg M S Staphylococcal food poisoning aboard a commercial aircraft. Lancet $1975 ; 27$ : 595-599.

Elaine M D'AS, Harrison MA, Willians SE, Broccoli MH Effectiveness of two coking systems in destroying Escherichia coli 0157: $\mathrm{H7}$ and Listeria monocytogenes in groud beef patties. J Food Protec 2000; 63 (7) : 894-899.

Fantasia MR e Filetici E. Salmonella enteritidis in Italia. Int J Food Microbiol 1994;21:7-13.

Florentino ER. Leite Júnior, AF, Sá SN, Araújo MSO, Martins RS. Avaliação da qualidade microbiológica da carne bovina comercializada em Campina Grande. Rev Hig Aliment 1997; 11 (47) : 34-37.

Franco BDGM. Landgraf M. Microbiologia dos alimentos. São Paulo: Ed. Atheneu, 1996.

Franco BDGM. Métodos alternativos de análise microbiológica de alimentos : Uma revisão. Bol SBCTA 1999; 33 (2): 229-234.

[FDA] Food And Drug Administration. Consumer.HACCP: The most modern focus for food safety. http://www.usiaq.usis.usem.se/journals /ites/0696/ijes/ejfafl.htm. [Jun/96].

Germano PML . Prevenção e controle das toxinfecções de origem alimentar. Rev Hig Aliment 1993 ; 7(27): 6-11. 
Germano PML, Germano MIS. A vigilância sanitária de alimentos como fator de promoção da saúde. 0 Mundo da Saúde 2000; 24(1): 59-65.

Hajdenwurcel JR. Atlas de microbiologia de alimentos. São Paulo. Fonte Comunicações Editora Ltda, 1998.

Hanashiro A, Torres EAFS, Germano MIS, Germano PML. Avaliação da comercialização de refeições orientais prontas -Bentôs- no bairro da Liberdade, São Paulo. Rev Hig Aliment 1999;13 (66,67):19-31.

Hataka M, Bjorkorth KJ, Asplund K, Maki-Petays N e Korkeala HJ. Genotypes and enterotoxicity of Staphylococcus aureus isolated from the hands and nasal cavities of flight-catering employees. J Food Protec 2000; 63 (11) : 1487 - 1491.

Hatakka M. Salmonella outbreak among railway and airline passengers. Acta vet scand $1992 ; 33(4): 253-260$.

Hatakka M., Asplund, K. The occurrence of Salmonella in airline meals. Acta vet scand $1993 ; 34(4): 391-396$.

Hataka M. Microbiological quality of cold meals served by airlines. I Food Safety 1998; $18: 185-195$.

Hataka M. Microbiological quality of hot meals served by airlines. I Food Protec 1998; 61 (8) : 1052-1056.

Hedberg CW, Levine WC, White KE, Carlson RH, Winsor DK, Cameron DN Mcdonald KL, Osterholm MT. An international foodborne outbreak of shigellosis associated with a comercial airline. JAMA 1992; 268 (22) : 32-40.

Henson S, Traill B. The demand for food safety. Market imperfections and the role of government. Food Policy 1993.

Heredia N, Garcia S, Rojas G, Salazar 1. Microbiological Condition of ground meat retailed in Monterrey, Mexico. J Food Protec 2001; 64 (8), 1249-1251.

Hoobs BC, Roberts D. As bactérias e outros agentes microbiológicos de intoxicações e infeç̧ões de origem alimentar. In: Toxinfeç̧ões e controle higiênico - sanitário de alimentos .São Paulo : Varela, 1999; 25-47.

ICMSF. APPCC na qualidade e segurança microbiológica de alimentos. Trad. D. Anna Terzi Giova. São Paulo: Livraria Varela; 1997.

Jakabi M, Buzzo AA, Ristori CA, Tavechio AT, Sakuma H, Paula AMR, Gelli DS. Observações laboratoriais sobre surtos alimentares de Salmonella spp, ocorridos na 
Grande São Paulo, no período de 1994 a 1997. Rev Inst Adolfo Lutz 1999;58 (1) : 47-51.

Jay IM Prevalence of Listeria spp in meat and poultry products. Food Control 1996; 7 (4/5): 209-214.

Jay JM Moderm food microbiology. Aspen Publishers, Gaithersburg, 2000.

Jiang X, Doyle MP. Fate of Escherichia coli 0157:H7 and Salmonella enteritidis on currency. J Food Protec 1999; 62 (7):805-807.

Karr KJ et al. Meat and Poultry Companies Asses USDA'S Hazard Analysis and Critical Control Point System. Food Technol 1994; 48 (2): 117-122.

Kelly M.J. Hygiene problems of in flight catering. Health and Hygiene 1984; 5, $37-$ 40.

Knight P. Hemorragic Escherichia cali: the danger increases. ASM News. 1993; 59 (5): $247-250$.

Lambiri M. et. al. The application of Hazard Analysis Critical Control Point (HACCP) in a flight catering establishement improved the bacteriological quality of meals. J Roy Soc Health. 1995; 115 (1): 26-30.

Lederer, J. Enciclopédia moderna de higiene alimentar. São Paulo, Manole dois, 1991.

Leitão MFF. Microrganismos patogênicos na carne e derivados. Boletim do ITAL. Campinas, 1978; 59: 15-48.

Levine P, Rose B , Green S, Ransom G, Hill W. Pathogen testing of read-to-eat meat and poutry products collected at federally inspected establishments in the United States, 1990-1999 J Food Protec 2001;64 (8) : 1188-1 193.

Lirio VS, Silva EA, Stefoni S, Camargo D, Recco EAP, Maluf YT. Freqüência de 17 sorotipos de Salmonella isolados em alimentos. Rev Hig Aliment 1998;12 (55): 36 42, 1998.

Loguercio AP, Silva WP, Aleixo JAG, Costa MM, Vargas AC. Listeria monocytogenes: Um importante patógeno de origem alimentar. Rev Hig Aliment $2001 ; 15(80): 39-48$

Matner RR, Fox TL, Mciver DE, Curiale MS Efficacy of Petrifilm E. coli count plates for $E$. coli and coliform enumeration J Food Protec 1990; 53(2):145-150

Mermelstein NH. Controlling E. coli 0157:H7 in meat. Food Technology 1993. 
Miguel M. Pontos críticos em preparações à base de carne de frango nas lanchonetes do campus de uma universidade. São Paulo, 1995 \{Tese de Doutorado - Faculdade de Saúde Pública- USP \} .

Mossel DAA, Moreno Garcia B. Microbiologia de los alimentos. Zaragoza, Editorial Acribia, 1982.

Murray PR et al. Mantral of Clinical Microbiology, $6^{\text {th }}$ ed. Am Soc Microb Washington, D.C., 1995.

Nardin MS, Silva M.V, Oterrer M. Segurança alimentar : uma necessidade brasileira. Sociedade Brasileira de Ciência e Tecnologia de Alimentos (SBCTA), 1997; 31(1) :68-76.

Nascimento RN e Stamford TLM. Incidencia de Escherichia coli 0157:H7 em alimentos. Rev Hig Aliment 2000;14 (70) : 32-35.

Neogen Corporation Profile. Reveal para E.coli O157:H7. Informe Técnico.2000a

Neogen Corporation Profile. Reveal para Salmonella. Informe Técnico.2000b

Nutsch A, Phebus RK, Riemann MJ Steam pasteurization of commercially slaughtered beef carcasses: evaluation of bacterial populations at five anatomical locations. J Food Protec 1998; 61 (5): 571-577.

Ormenese, RCSC, Silveira, NFA, Silva, N. Escherichia coli 0157:H7 em alimentos. Bol SBCTA. 1999; 33 (1): 41-49.

Oxoid. Rapid food tests. $2000<\mathrm{URL}$ :http://www.oxoidshop. com/scripts/wgate/ ww $10 />[2000 \mathrm{Dec} 1]$

Padhye, NV, Doyle, MP. . Escherichia coli 0157:H7 epidemiology, pathogenesis and methods for detectation in food. J Food Protec 1994; 55 (7) : 555-565.

Palmer S, Parry S, Perry D, Smith R, Evans M, Nehaul L, Roberts R, Walapu M, Wright $\mathrm{D}$. The role of outbreaks in developing food safety police ; population based surveillance of salmonella outbreaks in Wales 1986-1998 Epidemiol Infect 2000;125 : 467 - 472; 2000.

Panisello PJ, Rooney R, Quantick PC, Stanwell-Smith R. Application of foodborne disease outbreak data inthe development and maintenance of HACCP systems. J Food Microbiol 2000; $59: 221-234,2000$.

Picchi, V. Isolamento e identificação de Listeria spp em quartos dianteiros de bovinos desossados. Rev Hig Aliment 1999; 13 (63): 38-42. 
Riedel G. Controle sanitário dos alimentos. São Paulo: Livraria Atheneu, 1992.

Rogan A, Bernardi RA. Using statistical process control to evaluate Hazard Analysis Critical Control Point Plan Data. J Food Service System 1996;9:1-6.

Rocourt J. Risk factors for listeriosis. Food Control 1996;7(4/5):195-202.

Saad SMI e Franco BDGM. Influence of raw meat natural backgroud flora on growth of Escherichia coli 0157:H7 in ground beef. Revista de Microbiologia J Brazilian Society for Microbiology 1999; 30 (3):272-277.

Silva Jr E.A. Manual de controłe higiênico sanitário em alimentos. $3^{\circ}$ ed. São Paulo: Livraria Varela;1999.

Silva N, Junqueira VCA, Silveira NFA. Manual de métodos de análise microbiológica de alimentos. São Paulo : Livraria Varela, 1997.

Smith IL, Fratamico PM . Factors involved in the emergence and persistence of food born disease. J Food Protec 1995;58 (6) : 696-708.

Solis SC Gestão e certificação da qualidade de sistemas alimentares integrados. Rev Hig Aliment 1999;13 (61): 91-98.

Soriano JM, Rico H, Moltó JC e Mañes J. Listeria species in raw and ready-to-eat foods from restaurants. J Food Protec 2001;64 (4) :551-553.

Souza SM. Qualidade e segurança alimentar em catering aéreo baseado no método HACCP. In: SILVA JR, E.A. Manual de controle higiênico sanitário em alimentos. $3^{\circ}$ ed. São Paulo: Livraria Varela;1999.232-238:

Spers EE, Kassouf AL. A segurança dos alimentos: Uma preocupação crescente. Rev Hig Aliment 1996a; 10 (44): 18-21.

Spers EE, Kassouf AL. A abertura de mercado e a preocupação com a segurança dos alimentos. Rev Hig Aliment 1996b; 10 (46): 16-26.

Spers. EE. Qualidade e segurança em alimentos. In: ZILBERSZTAJN, D. e NEVES, M. F. Economia e gestão dos negócios agroalimentares. São Paulo: Pioneira; 2000.283-321.

Tauxe RM, Torney MP, Mascola L, Hargrett - Bean N T Blake P A . Salmonellosis outbreak on transatlantic flights: foodborne illness on aircraft 1948-1984. Am J Epidemiol 1987;125 : 150-157.

3M do Brasil. Alimentos e Bebidas. <URL : http: //international. 3M. com/intl/br/ 
produtos. html $>[2000 \mathrm{Dez} 03]$.

Viana CM. Enfermidades emergentes transmitidas por alimentos. In: Desafios em Ciência e tecnologia no Brasil - Emergência e Reemergência de Doenças Infecciesas e Parasitárias [Conselho Nacional de Desenvolvimento Científico e tecnológico]. Brasília, CNPq, 1998.

[WSDH] Washington State Department of Health. Public Health Fact Sheet. < URL : http://www.doh.wa.gov/topics/ecoli.htm. >1997 Last update [01/12/97].

[WHO] World Health Organization. The role of food safety in health and development. Genebra, 1984.

[WHO] World Health Organization.Seguranç básica dos alimentos para profissionais de saúde. Editores Martin Adams e Yasmine Motarjemi; tradução Andréa Favano. São Paulo : Editora Roca, 2002.

Wood EW. Food safety in the skies. Daily and Food Sanit 1987; 7 (9) : 464- 465.

Yang S, Angulo FJ, Altekruse SF. Evaluation of safe food - handling instructionson raw meat and poutry products. J Food Protec 63 (10): 1321-1325, 2000.

Yassien NA e EL Essawy EL. Bacterial quality of read to eat meals in air catering Vet Med J Giza 1990;1 : 1-9.

Zanardi AMP. Avaliação da aplicação do sistema de Análise de Perigos e Pontos Críticos de Controle (APPCC) em preparações com carne bovina em um serviço de refeições de bordo. São Paulo, 1998 \{Dissertação de Mestrado Faculdade de Saúde Pública - USP\}. 
Figura 4.8 - Procedimento para Teste REVEAL ${ }^{\mathrm{R}}$ Salmonella (Neogen)

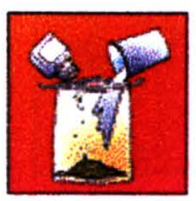

Re-hidratar o meio de pré-enriquecimento REVIVE com $200 \mathrm{~mL}$ de água estéril

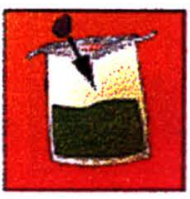

Adicionar $25 \mathrm{~g}$ de amostra. Incubar a $37^{\circ} \mathrm{C}$ durante 2 a 4 horas

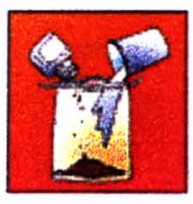

Re-hidratar o meio RAPPAPORT com $200 \mathrm{~mL}$ de água estéril

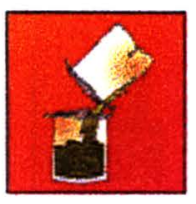

Adicionar todo o conteúdo do pré-enriquecimento em 200 $\mathrm{mL}$ do caldo RAPPAPORT. Incubar a $42^{\circ} \mathrm{C}$ durante 16 a 18 horas

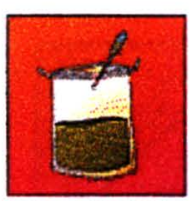

Retirar uma alíquota da amostra com pipeta que acompanha o kit

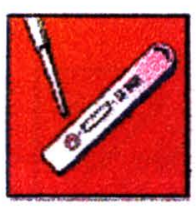

Adicionar 5 gotas da amostra na porta do mecanismo teste (o dispositivo deve estar em temperatura ambiente)

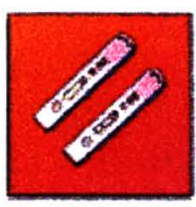

Observar o resultado após 20 minutos

Negativo : Linha vermelha escuro em C e não aparece linha vermelha em $\mathrm{T}$

Positivo : Linha vermelha escuro em C e T 
Figura 4.9 - Procedimento REVEAL para $E$. coli 0157:H7 (Neogen)

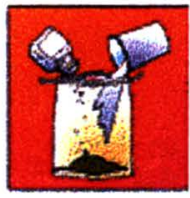

Re-hidratar o meio de cultura Reveal $8 \mathrm{com} 225 \mathrm{~mL}$ de água estéril

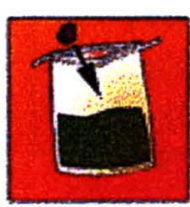

Adicionar $25 \mathrm{~g}$ da amostra. Incubar a $42^{\circ} \mathrm{C}$ durante 8 horas

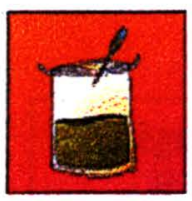

Retirar da incubadora e transferir com auxilio de pipeta $10 \mathrm{~mL}$ deste caldo para um tubo de ensaio

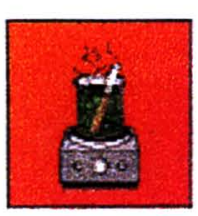

Aquecer em banho-maria a $100^{\circ} \mathrm{C}$ durante 10 minutos

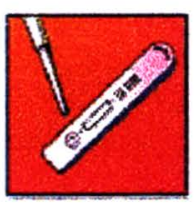

Adicionar 5 gotas da amostra no círculo do dispositivo

Observar o resultado após 20 minutos

Negativo : Linha vermelho escura em $\mathrm{C}$ e não aparece linha em $\mathrm{T}$

Positivo : Linha vermelho escura em C e T 
Figura 4.10 - Procedimento para verificação da presença de Listeria spp por meio do Listeria Rapid Test Method - OXOID

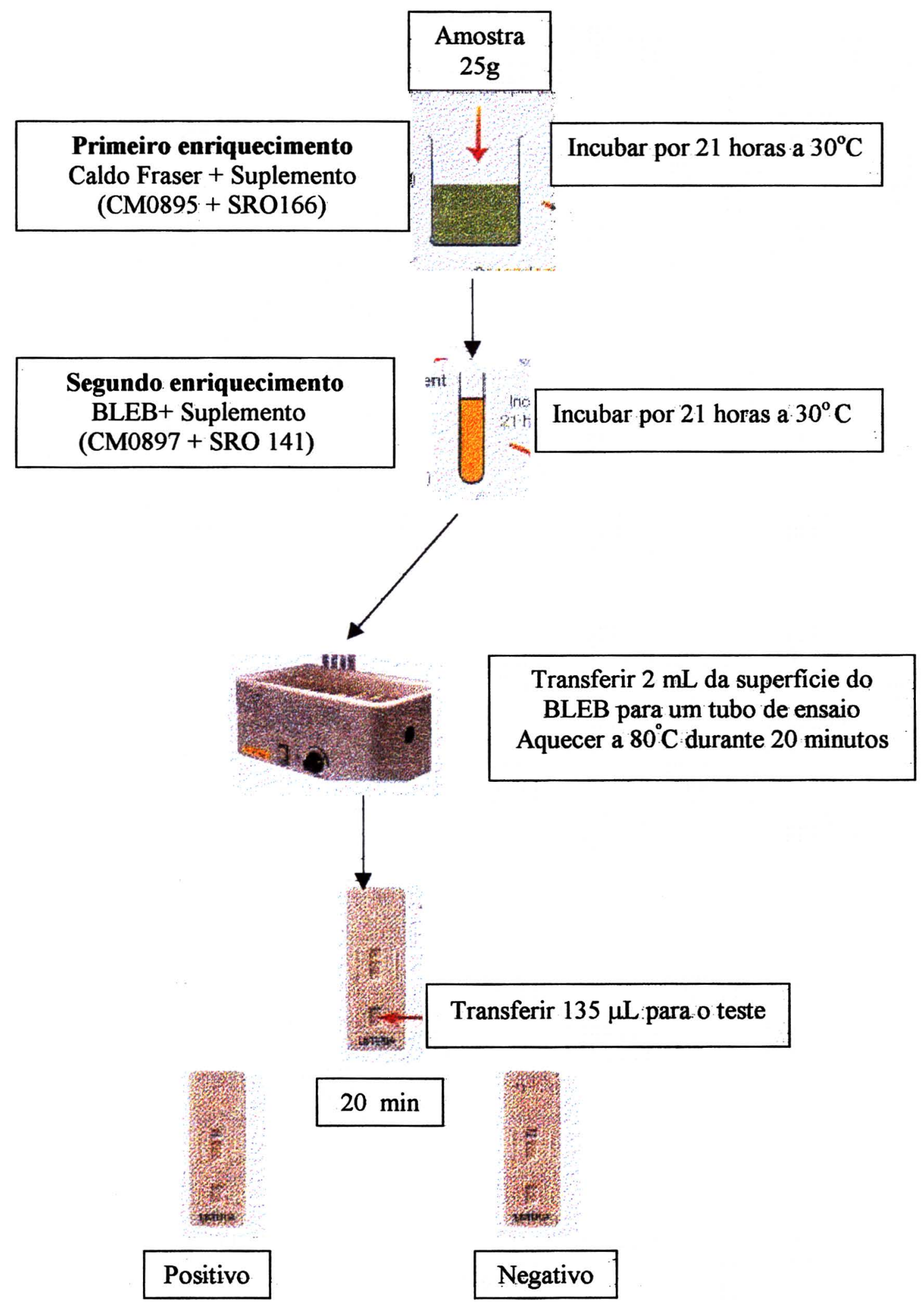


Quadro 5.1 - Distribuição das amostras quanto ao tipo de preparação, características da preparação, tempo de embalagem e temperatura no momento da coleta

\begin{tabular}{|c|c|c|c|c|}
\hline Amostra & Tipo de preparação & $\begin{array}{c}\text { Características da } \\
\text { preparação }\end{array}$ & $\begin{array}{c}\text { Tempo de } \\
\text { embalagem }\end{array}$ & Temperatura $\left({ }^{\circ} \mathrm{C}\right)$ \\
\hline 1 & lagarto assado fatiado & bem passada & no dia da análise & 7,0 \\
\hline 2 & tornedor & mat passada & no dia da análise & 7,0 \\
\hline 3 & rosbife & muito mal passada & no dia da análise & 8,0 \\
\hline 4 & escalope de filé & mal passada & no dia da anátise & 6,0 \\
\hline 5 & escalope de filé & bem passaida & 24 horas & 9,0 \\
\hline 6 & goulash & bem passada & 24 horas & 9,5 \\
\hline 7 & escalope de filé & bem passada & 24 horas & 10,0 \\
\hline 8 & escalope de filé & bem passada & 24 horas & 10,5 \\
\hline 9 & tornedor & mal passada & 24 horas & 8,5 \\
\hline 10 & tornedor & mal passada & no dia da análise & 14,0 \\
\hline 11 & escalope de fité & melito mal passada & no dia da análise & 14,0 \\
\hline 12 & escalope de filé & bem passada & no dia da análise & 18,0 \\
\hline 13 & lagarto assado fatiado & bem passaida & no dia da análise & 17,5 \\
\hline 14 & filé á parmeggiana & bem passada & 24 horas & 14,0 \\
\hline 15 & tomedor & mal passada & no dia da análise & 11,0 \\
\hline 16 & tornedor & mal passada & no dia da análise & 17,0 \\
\hline 17 & lagarto assado fatiado & bem passada & no dia da análise & 12,0 \\
\hline 18 & goulash & bem passada & no dia da análise & 11,0 \\
\hline 19 & rosbife & mal passada & no dia da análise & 11,5 \\
\hline 20 & tornedor & muito mal passada & no dia da análise & 11,5 \\
\hline 21 & tornedor & muito mal passada & no dia da análise & 11,5 \\
\hline 22 & tornedor & mutito mal passada & no dia da análise & 10,0 \\
\hline 23 & tomedor & mal passada & no dia da análise & 9,0 \\
\hline 24 & brochete de fié & mal passada & 24 horas & 8,0 \\
\hline 25 & rosbife & mat passada & 24 horas & 9,0 \\
\hline
\end{tabular}




\begin{tabular}{|c|c|c|c|c|}
\hline Amostra & Tipo de preparação & $\begin{array}{c}\text { Característica da } \\
\text { preparação }\end{array}$ & $\begin{array}{l}\text { Tempo de } \\
\text { embalagem }\end{array}$ & Temperatura $\left({ }^{\circ} \mathrm{C}\right)$ \\
\hline 26 & goulash & bem passaita & no dia da análise & 10,0 \\
\hline 27 & tornedor & muito mal passada & no dja da análise & 9,0 \\
\hline 28 & tornedor & muito mal passada & 24 horas & 5,5 \\
\hline 29 & escalope de filé & bem passata & no dia da análise & 17,0 \\
\hline 30 & tornedor & muito mal passada & no dia da análise & 17,0 \\
\hline 31 & escalope de filé & maf passada & 24 horas & 12,0 \\
\hline 32 & escalope de filé & muito mal passada & no dia da análise & 13,0 \\
\hline 33 & escalope de filé & mal passada & no dia da anátise & 17,0 \\
\hline 34 & escalope de filé & mal passada & no dia da análise & 17,0 \\
\hline 35 & escalope de filé & bem passada & no dia da análise & 8,5 \\
\hline 36 & bife á pamreggiana & bem passaida & 24 horas & 7,5 \\
\hline 37 & rosbife & mal passada & no dia da análise & 8,0 \\
\hline 38 & escalope de filé & bem passada & no dia da análise & 8,0 \\
\hline 39 & tomedor & muito mal passada & no dia da análise & 95 \\
\hline 40 & tornedor & mal passada & 24 horas & 10.5 \\
\hline 41 & goulash & bem passada & no dia da análise & 9,0 \\
\hline 42 & tornedor & mal passada & no dia da análise & 9,0 \\
\hline 43 & goulash & mal passada & no dia da análise & 15,0 \\
\hline 44 & brochete de filé & muito mal passada & 24 horas & 9,5 \\
\hline 45 & tomedor & muifto mal passada & no dia da análise & 14.0 \\
\hline 46 & escalope de file & bem passada & 24 horas & 110 \\
\hline 47 & tomedor & mal passacta & no dia da análise & 11,0 \\
\hline 48 & tomedor & muito mal passada & 24 horas & 13.0 \\
\hline 49 & tomedor & mat passadia & no dia da análise & 12,0 \\
\hline 50 & tomedor & mat passada & 24 horas & 11,0 \\
\hline
\end{tabular}


Quadro 5.2- Resultados das análises microbiológicas

\begin{tabular}{|c|c|c|c|c|}
\hline Amostra & Salmonella spp & Listeria spp & S. aureus & E. coli 0157:H7 \\
\hline 1 & negativo & negativo & negativo & negativo \\
\hline 2 & negativo & negativo & negativo & negativo \\
\hline 3 & negativo & negativo & negativo & negativo \\
\hline 4 & negativo & positivo & negativo & negativo \\
\hline 5 & negativo & negativo & negativo & negativo \\
\hline 6 & positivo & negativo & negativo & negativo \\
\hline 7 & negativo & negativo & negativo & negativo \\
\hline 8 & negativo & negativo & negativo & negativo \\
\hline 9 & negativo & negativo & negativo & negativo \\
\hline 10 & negativo & negativo & negativo & negativo \\
\hline 11 & positivo & negativo & negativo & negativo \\
\hline 12 & negativo & negativo & negativo & negativo \\
\hline 13 & negativo & negativo & negativo & negativo \\
\hline 14 & positivo & positivo & negativo & negativo \\
\hline 15 & positivo & negativo. & negativo & negativo \\
\hline 16 & negativo & negativo & negativo & negativo \\
\hline 17 & negativo & negativo & negativo & negativo \\
\hline 18 & negativo & negativo & negativo & negativo \\
\hline 19 & negativo & negativo & negativo & negativo \\
\hline 20 & negativo & negativo & negativo & negativo \\
\hline 21 & negativo & negativo & negativo & negativo \\
\hline 22 & positivo & negativo & negativo & negativo \\
\hline 23 & negativo & negativo & negativo & negativo \\
\hline 24 & positivo & negativo & negativo & negativo \\
\hline 25 & positivo & negativo & negativo & negativo \\
\hline
\end{tabular}




\begin{tabular}{|c|c|c|c|c|}
\hline Amostra & Salmonella spp & Listeria spp & S. aureus & $\begin{array}{c}\text { E. coli } \\
0157: H 7\end{array}$ \\
\hline 26 & positivo & negativo & negativo & negativo \\
\hline 27 & negativo & negativo & negativo & negativo \\
\hline 28 & positivo & negativo & negativo & negativo \\
\hline 29 & positivo & negativo & negativo & negativo \\
\hline 30 & positivo & negativo & negativo & negativo \\
\hline 31 & negativo & negativo & negativo & negativo \\
\hline 32 & negativo & positivo & negativo & negativo \\
\hline 33 & positivo & negativo & negativo & negativo \\
\hline 34 & positivo & negativo & negativo & negativo \\
\hline 35 & positivo & negativo & negativo & negativo \\
\hline 36 & negativo & negativo & negativo & negativo \\
\hline 37 & negativo & negativo & negativo & negativo \\
\hline 38 & positivo & negativo & negativo & negativo \\
\hline 39 & positivo & negative & negativo & negativo \\
\hline 40 & negativo & negativo & negativo & negativo \\
\hline 41 & negativo & negativo & negativo & negativo \\
\hline 42 & negativo & negativo & negativo & negativo \\
\hline 43 & negativo & negativo & negativo & negativo \\
\hline 44 & negativo & negativo & negativo & negativo \\
\hline 45 & negativo & negativo & negativo & negativo \\
\hline 46 & negativo & negativo & negativo & negativo \\
\hline 47 & negativo & negativo & negativo & negativo \\
\hline 48 & negativo & negativo & negativo & negativo \\
\hline 49 & negativo & negativo & negativo & negativo \\
\hline 50 & negativo & negativo & negativo & negativo \\
\hline
\end{tabular}




\section{GLOSSÁRIO}

- Brochete de filé: filé mignon, cortado em cubos, colocado em espeto e assado

- Escalope de filé: filé mignon, cortado em duas fatias, marcado na chapa e assado

- Filé à parmeggiana: filé mignon, cortado em bife, empanado em farinha e ovo, coberto com muzzarela e assado

- Goulash: pontas de filé mignon, cortado em cubos e cozido

- Lagarto assado fatiado: lagarto inteiro assado e depois fatiado

- Rosbife: filé mignon assado inteiro

- Tornedor de filé mignon: filé mignon cortado em fatias grossas $(2 \mathrm{~cm})$, e depois assado 